\title{
The petrology of a hazardous volcano: Calbuco (Central Southern Volcanic Zone, Chile)
}

\author{
Jacqueline Vander Auwera ${ }^{1}$ (D) $\cdot$ Salvatrice Montalbano ${ }^{1} \cdot$ Olivier Namur $^{1,2,3} \cdot$ Tonin Bechon $^{1} \cdot$ Pierre Schiano $^{4}$. \\ Jean-Luc Devidal ${ }^{4}$. Olivier Bolle ${ }^{1}$
}

Received: 2 November 2020 / Accepted: 3 May 2021

(c) The Author(s), under exclusive licence to Springer-Verlag GmbH Germany, part of Springer Nature 2021

\begin{abstract}
The recurrent explosive eruptions of Calbuco (Andean Southern Volcanic Zone (SVZ)) threat a rapidly expanding touristic and economic region of Chile. Providing tighter constraints on its magmatic system is therefore important for better monitoring its activity. Calbuco is also distinguished by hornblende-bearing assemblages that contrast with the anhydrous parageneses of most Central SVZ volcanoes. Here we build on previous work to propose a detailed petrological model of the magmatic system beneath Calbuco. Geochemical data acquired on a hundred samples collected in the four units of the

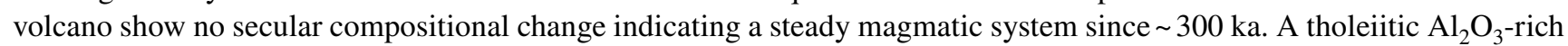

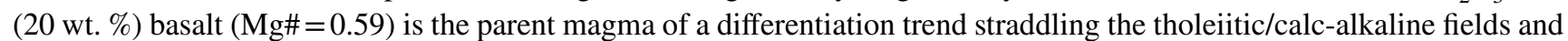
displaying a narrow compositional Daly gap. Amphibole crystallization was enabled by the higher $\mathrm{H}_{2} \mathrm{O}$ content of the basalt (3-3.5 wt. $\% \mathrm{H}_{2} \mathrm{O}$ at $50 \mathrm{wt}$. \% $\mathrm{SiO}_{2}$ ) compared to neighboring volcanoes. This characteristic is inherited from the primary mantle melt and possibly results from a lower degree of partial melting induced by the mantle wedge thermal structure. Although macrocrysts are not all in chemical equilibrium with their host rocks and were thus presumably unlocked from the zoned crystal mush and transported in the carrier melt, the bulk-rock trend follows both experimental liquid lines of descent and the chemical trend of calculated melts in equilibrium with amphibole (AEMs). These contradictory observations can be reconciled if minerals are transported in near cotectic proportions. The AEMs overlap the Daly gap revealing that the missing liquid compositions were present in the storage region. Geothermobarometers all indicate that the chemical diversity from basalt to dacite was acquired at a shallow depth (210-460 MPa). We suggest that differentiation from the primary magma to the parental basalt took place either in the same storage region or at the MOHO.
\end{abstract}

Keywords Arc magmatism $\cdot$ Calbuco $\cdot$ Amphibole $\cdot$ Storage depth $\cdot$ Magmatic processes

Communicated by Timothy L. Grove.

Jacqueline Vander Auwera
jvdauwera@uliege.be
Salvatrice Montalbano
salvatrice.montalbano@uliege.be
Olivier Namur
olivier.namur@kuleuven.be
Tonin Bechon
tonin.bechon@uliege.be
Pierre Schiano
pierre.schiano@uca.fr
Jean-Luc Devidal
j.l.devidal@ opgc.univ-bpclermont.fr

Jacqueline Vander Auwera

salvatrice.montalbano@uliege.be

Olivier Namur

olivier.namur@kuleuven.be

Tonin Bechon

Tuliege.be

Pierre Schiano

j.1.devidal@opgc.univ-bpclermont.fr
Olivier Bolle

olivier.bolle@uliege.be

1 Département de Géologie, Université de Liège, 4000 Liège, Belgium

2 Institute of Mineralogy, Leibniz Universität Hannover, 30167 Hannover, Germany

3 Department of Earth and Environmental Sciences, University of Leuven, 3001 Leuven, Belgium

4 Laboratoire Magmas et Volcans, Université Clermont Auvergne, Clermont-Ferrand, France 


\section{Introduction}

Monitoring of active volcanoes as well as analysis of their eruptive history indicate that each edifice has its own chemical and physical characteristics, emphasizing the critical need for detailed petrological studies of individual volcanoes (e.g. Bachmann et al. 2011; Bouvet De Maisonneuve et al. 2013; Longpré et al. 2014; Ruth et al. 2016). This is particularly true for hazardous ones located in populated areas. Several parameters that are crucial for improving volcanic hazard assessment such as the depth of magma storage, the composition, including volatiles, of erupted magmas that dictates viscosity and thus potential explosivity, and reconstruction of the magma plumbing system can be derived from petrological data (Gudmundsson 2012). More generally, better forecasting depends on our understanding of shallow and deep volcanic (magmatic) processes. Together with Villarrica and Llaima, Calbuco is one of the most hazardous and active volcanoes in the Southern Andes as witnessed by its recurrent explosivity and its 2015 sub-Plinian eruption that caused significant damage to the local communities and disrupted Chilean and Argentinean air traffic. This eruption had also severe economic consequences for one of Chile's key salmon-farming and agricultural area (Hayes et al. 2019). Calbuco is a truncated-cone shaped stratovolcano located on the southern shore of lake Llanquihue in the Central Southern Volcanic Zone (CSVZ, 41ํㅇ' S) (Fig. 1). It is remarkable by the presence of amphibole and of relatively abundant andesites, features rarely observed in the CSVZ and more particularly in nearby volcanoes (Osorno, La Picada) (Hickey-Vargas et al. 2016b; Lopez-Escobar et al. 1995; Vander Auwera et al. 2019). Calbuco thus represents a type example of the "hydrous" volcanoes of the CSVZ.

The first detailed work on Calbuco was by Lopez-Escobar et al (1995). They subdivided the eruptive products into four temporal units and focused on the geochemistry (major and trace elements) and isotopic composition $(\mathrm{Sr}, \mathrm{Nd}, \mathrm{Pb})$ of a dozen samples. They proposed that some crustal assimilation (about 10\%) of metasedimentary rocks sufficiently raised the water content of the magma to enable the crystallization of amphibole, an hypothesis later questioned by Sellés et al. (2004) who suggested that even if elevated Sr isotopic ratios support a contamination process, water was probably inherited from the mantle. Lopez-Escobar et al (1995) also qualitatively estimated that the composition of the andesite

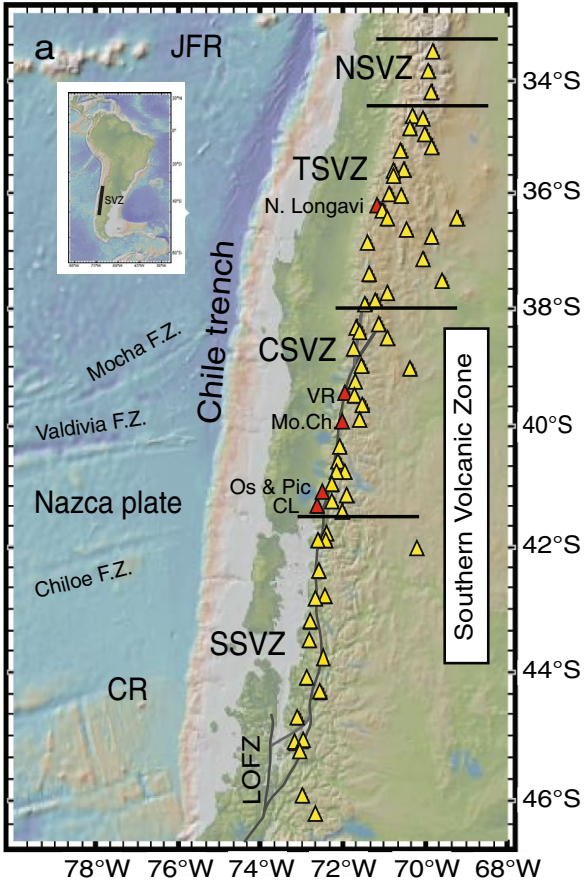

Fig. 1 a Global multi-resolution topography (GMRT) map of the Andean Southern Volcanic Zone (SVZ) showing the location of Calbuco (CL), La Picada (Pic) merging with that of Osorno (Os), Mocho-Choshuenco (Mo.Ch.), Villarrica (VR) and Nevado de Longavi (N. Longavi) (red triangles), among the chain of active volcanoes (yellow triangles). NSVZ, TSVZ, CSVZ and SSVZ designate the different segments of the SVZ, respectively the Northern, Transitional, Central and Southern SVZ (after Hickey-Vargas et al. 2016a;
Lopez-Escobar et al. 1995). LOFZ is the Liquiñe Ofqui Fault Zone (after Cembrano and Lara 2009). The Juan Fernandez Ridge (JFR), Chile Rise (CR) as well as the Mocha, Valdivia and Chiloe Fracture Zones are also displayed. The inset map shows the location of the SVZ in South America. Maps constructed using GeoMapApp. b View of the truncated cone and northern flank of Calbuco after the 2015 eruption 
dominantly observed in Calbuco could be reproduced by $30 \%$ to $50 \%$ fractionation of a gabbronoritic cumulate from a parental basaltic andesite.

The recent 2015 eruption initiated several studies that have provided constraints on the current magma storage region beneath Calbuco. A collection of geothermobarometers all converge to a shallow depth (200-300 MPa) of the main storage region (Arzilli et al. 2019; Morgado et al. 2019b; Namur et al. 2020) and temperature ranges that agree with experimental data on suitable compositions (e.g. Parat et al. 2014) $\left(882-1019{ }^{\circ} \mathrm{C}\right.$ : Morgado et al. 2019b; 898-1160 ${ }^{\circ} \mathrm{C}$ : Namur et al. 2020; 900-950 ${ }^{\circ} \mathrm{C}$ : Arzilli et al. 2019), results confirmed by this study. The eruption could have been triggered either by a hot mafic magma recharge at the base of the shallow reservoir (Morgado et al. 2019a; Namur et al. 2020) and/or by second boiling (Arzilli et al. 2019; Namur et al. 2020). Based on an extensive geochemical dataset, Namur et al. (2020) demonstrated that the limited compositional variation of the 2015 pyroclasts results from the variable accumulation of plagioclase and pyroxenes (25-36\% of an assemblage of $72 \% \mathrm{Pl}+14 \% \mathrm{Opx}+14 \% \mathrm{Cpx}$ : abbreviations for mineral names from Whitney and Evans (2010)), in a dacitic melt, the different phases displaying a rather constant composition. As this trend mimics a liquid line of descent, these authors further suggested that the crystals are transported in near-cotectical proportions. Namur et al. (2020) also demonstrated that the highly anorthitic cores (median $\mathrm{An}_{87.7}$ ) that are ubiquist in plagioclase macrocrysts likely crystallized from a basaltic andesite (52 wt. $\% \mathrm{SiO}_{2}, 5-6$ wt. \% $\mathrm{MgO}$ ) with 3.5-4.5 wt. \% $\mathrm{H}_{2} \mathrm{O}$.

In this new study, we present a comprehensive petrological study focusing on the lavas and pyroclasts erupted by Calbuco during its $\sim 300$ ka activity. Our aim is to build on previous work and to use detailed whole-rock and mineral compositions to decipher the magmatic processes and the crustal column that lies beneath this hazardous volcano.

\section{The Calbuco volcano in the Central Southern Volcanic Zone}

In the CSVZ, the volcanism is induced by the subduction of the Nazca plate below South America with an average dip angle of $39^{\circ}$ (Syracuse and Abers 2006) and at a rate of $66 \mathrm{~mm} /$ year (Angermann et al. 1999). At the latitude of $39^{\circ} 24^{\prime}$ S, Dzierma et al. (2012) found a slab dip of about $35^{\circ}$ and a MOHO depth of 30-40 km using trench-perpendicular seismic profiles. The northern limit of the CSVZ at $38^{\circ} \mathrm{S}$ is defined by the end of the Liquiñe-Ofqui Fault Zone (LOFZ), a $1200 \mathrm{~km}$-long transpressional NNE-trending dextral strikeslip structure (Hickey-Vargas et al. 2016b) (Fig. 1). It also corresponds to the changing composition of the basement from Meso-Cenozoic volcano-sedimentary rocks in the north to Meso-Cenozoic plutonic rocks of the Patagonian Batholith in the south (Cembrano and Lara 2009; Parada et al. 1987). This limit also marks a change in the composition of Quaternary volcanic rocks that are dominated by andesites to dacites in the north and by basalts and basaltic andesites in the south (Hickey-Vargas et al. 2016b).

Calbuco is emplaced about $30 \mathrm{~km}$ to the west of the LOFZ (Fig. 1) and its position does not seem to be related to any other major crustal structure (Lopez-Escobar et al. 1992). However, Parada, et al. (1987) noted that dextral movement along the LOFZ may have induced NE tension fractures, oblique to the LOFZ, that probably favored the emplacement of Miocene plutonic units belonging to the North Patagonian batholith and located just south of Calbuco. Moreover, the South American Risk Assessment (SARA) project has identified a local fracture that is located exactly below Calbuco. These fractures may provide crustal pathways for the magmas (Fig. 2). Calbuco is made of blocky and Aa lavas interbedded with pyroclastic deposits. Its history spans from 342 ka to present (Sellés and Moreno 2011). It has thus been affected by the last three glaciations (Rio Llico (480-338 ka); Santa Maria (262-132 ka); Llanquihue (90-14.5 ka); Clayton et al. (1997) cited in Sellés and Moreno (2011), Porter (1981)). On the basis of morphostructural criteria and radiometric ages (Ar-Ar, K-Ar), its eruptive products have been subdivided in four units

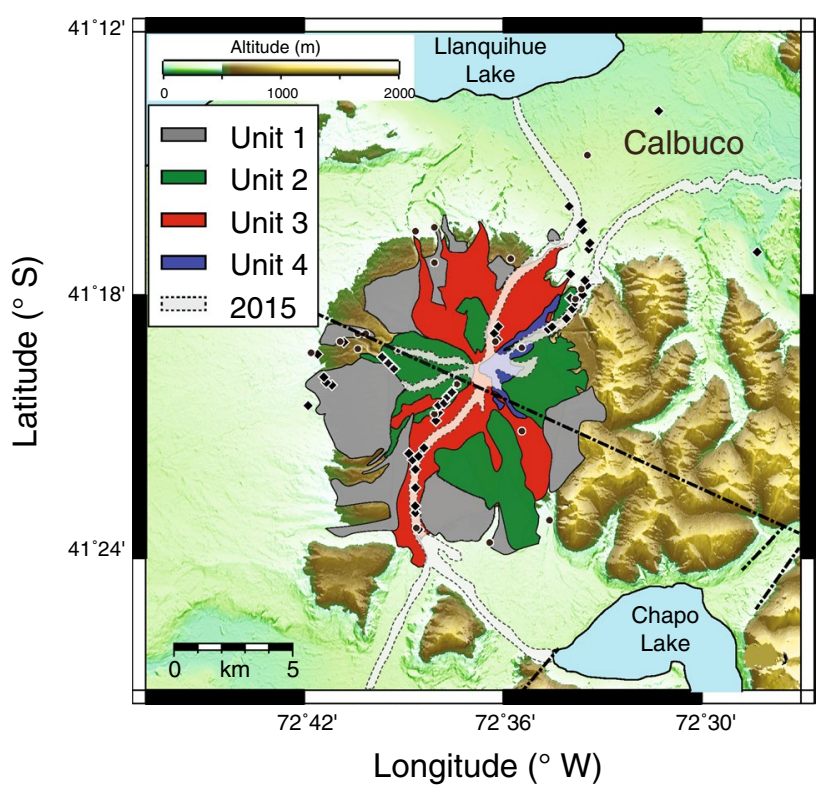

Fig. 2 Schematic map showing the four units of Calbuco identified by Lopez-Escobar et al. (1995) and Sellés and Moreno (2011) and the location of our samples (black diamonds) and those of Sellés and Moreno (2011) (black filled circles). The distribution of the 2015 eruptive products (pyroclasts and lahars) is from Castruccio et al. (2016). The dashed dotted lines are tension fractures related to the LOFZ (NE oriented from Parada et al. 1987) and SE oriented from the SARA project: https://sara.openquake.org/hazard_rt2) 
by Lopez-Escobar et al. (1995) and Sellés and Moreno (2011) (Fig. 2). The lowermost unit of the volcano, Unit 1 (342-110 ka: Sellés and Moreno (2011)), is essentially made of basaltic andesite lavas intercalated with volcanoclastic deposits that rest unconformably on the basement. The latter comprises Miocene granitoids from the Northern Patagonian Batholith, Early Pleistocene deposits possibly belonging to an old stratovolcano emplaced a few km east of Calbuco as well as mafic and metasedimentary metamorphic rocks (Lopez-Escobar et al. 1992). Unit 2 (110-14.5 ka: Sellés and Moreno (2011)) represents a significant part of the upper structure of the volcano with mostly andesitic lavas and intercalated pyroclastic deposits. At the end of the last glaciation (Llanquihue), a major slide produced an avalanche of debris and a horse shoe caldera opened to the NE close to the Llanquihue lake. Unit 3 postdates the last glaciation and is made of mostly basaltic andesitic lavas and pyroclastic deposits that form the modern cone of the volcano. The major Alerce ignimbrite belongs to this unit. Unit 4 (> 1893) comprises the historical lava flows that formed a dome inside the central crater or escaped the crater (1912, $1917,1929,1961)$. The last 2015 explosive eruption consisted in two main pulses that produced sub-Plinian columns ( $>15 \mathrm{~km}$ height) and pyroclastic density currents that travelled down to $8 \mathrm{~km}$ from the vent (Castruccio et al. 2016; Romero et al. 2016; Van Eaton et al. 2016) (Fig. 2). The tephra $\left(0.27 \pm 0.007 \mathrm{~km}^{3}\right.$ : Romero et al. (2016); $0.38 \pm 0.1$ $\mathrm{km}^{3}$ : Castruccio et al. (2016); $0.58 \pm 0.28 \mathrm{~km}^{3}$ : Van Eaton et al. (2016)) were essentially deposited on the northeastern part of the volcano and the finest ash dispersed across Chile, Argentina and Uruguay. They mainly consist of a basaltic andesite (Castruccio et al. 2016; Romero et al. 2016; Morgado et al. 2019b; Namur et al. 2020) with a high amount of crystals (35 to 65 vol. \%), plagioclase, orthopyroxene and clinopyroxene being dominant. Xenoliths of varying size ( $\mathrm{cm}$ to $\mathrm{dm}$ ) are common in some Calbuco lavas and have been subdivided in granulites and hornblende-rich gabbronorites, respectively interpreted as metamorphosed MORB-like basalts and cognate enclaves by Hickey-Vargas et al. (1995).

\section{Sample collection}

Access to Calbuco volcano is not straightforward as there exists only a few trails maintained by park rangers. Moreover, the lower units are covered by a dense vegetation of mostly bamboos and Alerce trees that severely limit progression. Consequently, the samples were collected in a selection of accessible zones of the volcano during several field missions $(2013,2014,2015,2016)$ that were also devoted to the sampling of nearby volcanoes (Fig. 2) (Supplementary Table 1). The sample suite consists of lavas
(49), volcanic bombs (21) and blocks (25) collected in the 4 units of Calbuco mapped by Sellés and Moreno (2011) and thus covers the whole eruptive history of the volcano (Fig. 2). Samples of the 2015 eruption (Namur et al. 2020) are used here for comparison. Lavas were preferentially sampled in the inner part of individual flows where vesicles are less abundant and the texture is more massive. The bombs were included in pyroclastic deposits whereas the blocks were taken on the ground. Three samples of granulitic enclaves and two samples of the basement (granitoids) were included in the dataset.

\section{Analytical methods}

\section{Electron microprobe microanalysis}

The major element composition of minerals was measured with a CAMECA SX100 at the Laboratoire Magmas et Volcans (LMV) (Université Clermont Auvergne, France) using an accelerating voltage of $15 \mathrm{kV}$, a beam current of $10 \mathrm{nA}$ except for $\mathrm{Ni}(100 \mathrm{nA})$ and a focused beam $(1 \mu)$. Counting times were $20 \mathrm{~s}$ for $\mathrm{Mg}$ and $\mathrm{Mn}, 30 \mathrm{~s}$ for $\mathrm{Fe}$ and $\mathrm{Ca}, 10 \mathrm{~s}$ for $\mathrm{Si}, \mathrm{Ti}, \mathrm{Al}, \mathrm{Na}$ and $\mathrm{K}$ as well as $60 \mathrm{~s}$ for Ni. The composition of interstitial glass was measured with a beam current of 4-8 nA, and a defocused beam of 5-10 $\mu \mathrm{m}$ depending on the size of the glass pocket. Counting times were $40 \mathrm{~s}$ for $\mathrm{K}$ and $\mathrm{Fe}, 30 \mathrm{~s}$ for $\mathrm{Mn}, 20 \mathrm{~s}$ for $\mathrm{Al}$ and $\mathrm{Mg}$ and $10 \mathrm{~s}$ for other elements. Calibration standards were wollastonite $(\mathrm{Ca}$, $\mathrm{Si}$ ), $\mathrm{TiMnO}_{3}(\mathrm{Ti}, \mathrm{Mn}), \mathrm{Al}_{2} \mathrm{O}_{3}(\mathrm{Al}), \mathrm{Cr}_{2} \mathrm{O}_{3}(\mathrm{Cr})$, fayalite (Fe), forsterite $(\mathrm{Mg})$, albite $(\mathrm{Na})$, orthose $(\mathrm{K})$ and $\mathrm{NiO}(\mathrm{Ni})$. The standard deviation of repeat analyses of standard VG-A99 is better than $\pm 5 \%$ for all major elements except $\mathrm{MnO}( \pm$ $33.7 \%)$ and $\mathrm{P}_{2} \mathrm{O}_{5}( \pm 17 \%)$. Compositional profiles were acquired for plagioclase, pyroxenes and olivine using the same analytical conditions except that a counting time of $60 \mathrm{~s}$ was used for Fe in plagioclase. Mineral composition analyses of samples CL148, CL149 and CL73 were performed with the CAMECA SXFIVE Tactis (LMV, Université Clermont Auvergne, Clermont-Ferrand, France) using an accelerating voltage of $15 \mathrm{kV}$, a beam current of $15 \mathrm{nA}$ and a focused beam. Counting times were $10 \mathrm{~s}$ for all the elements excepted for $\mathrm{Ni}$ and $\mathrm{Al}$ in olivine $(20 \mathrm{~s}$ and $60 \mathrm{~s}$, respectively). Calibration standards were San Carlos olivine ( $\mathrm{Si}$ in olivine), wollastonite $(\mathrm{Ca}, \mathrm{Si}$ for other silicates minerals), $\mathrm{TiMnO}_{3}(\mathrm{Ti}, \mathrm{Mn}), \mathrm{Al}_{2} \mathrm{O}_{3}(\mathrm{Al}), \mathrm{Cr}_{2} \mathrm{O}_{3}(\mathrm{Cr})$, fayalite $(\mathrm{Fe})$, forsterite $(\mathrm{Mg})$, albite $(\mathrm{Na})$, orthose $(\mathrm{K})$ and $\mathrm{NiO}(\mathrm{Ni})$. A few analyses have been performed with a CAMECA SX50 at the University of Mons (Belgium) using an accelerating voltage of $15 \mathrm{kV}$, a beam current of $20 \mathrm{nA}$ and a focused beam. Counting times were $20 \mathrm{~s}$ for $\mathrm{Na}, \mathrm{Mg}$ and $\mathrm{K}, 15 \mathrm{~s}$ for $\mathrm{Al}$ and $\mathrm{Si}, 25 \mathrm{~s}$ for $\mathrm{Fe}, \mathrm{Mn}$ and $\mathrm{Ti}$ and $55 \mathrm{~s}$ for $\mathrm{Ca}$. Standards were oligoclase $(\mathrm{Na})$, periclase $(\mathrm{Mg})$, sapphire $(\mathrm{Al})$, wollastonite 
( $\mathrm{Si}, \mathrm{Ca})$, leucite $(\mathrm{K})$, hematite $(\mathrm{Fe})$, rutile $(\mathrm{Ti})$ and rhodonite (Mn) (Supplementary Table 2).

\section{Laser ablation inductively coupled plasma mass spectrometry}

Plagioclase and olivine from the troctolitic glomerocrysts of sample CL149 were analysed in situ for trace elements by LA-ICP-MS (LMV, Université Clermont Auvergne, Clermont-Ferrand, France) with a Thermofischer Element XR ICP-MS coupled to a Resonetics M-50 excimer Ar/F laser ablation system operating at a wavelength of $193 \mathrm{~nm}$. Spot diameters ranging from 93 to $133 \mu \mathrm{m}$ were used with a fluency of $2.8 \mathrm{~J} / \mathrm{cm}^{2}$ and a repetition rate of $3 \mathrm{~Hz}$ in order to minimize fractionation effects. Ablation was conducted in pure $\mathrm{He}$ atmosphere, then the ablated material was carried to the plasma in an $\mathrm{Ar} / \mathrm{He} / \mathrm{N}_{2}$ gas stream. Instrument tuning and mass calibration were performed using N612 (20-40 ppm) reference glass before every analytical session. The following isotopes were measured: ${ }^{39} \mathrm{~K},{ }^{43} \mathrm{Ca},{ }^{44} \mathrm{Ca},{ }^{45} \mathrm{Sc},{ }^{49} \mathrm{Ti},{ }^{51} \mathrm{~V}$, ${ }^{53} \mathrm{Cr},{ }^{57} \mathrm{Fe},{ }^{59} \mathrm{Co},{ }^{60} \mathrm{Ni},{ }^{66} \mathrm{Zn},{ }^{85} \mathrm{Rb},{ }^{88} \mathrm{Sr},{ }^{89} \mathrm{Y},{ }^{90} \mathrm{Zr},{ }^{93} \mathrm{Nb},{ }^{133} \mathrm{Cs}$, ${ }^{137} \mathrm{Ba},{ }^{139} \mathrm{La},{ }^{140} \mathrm{Ce},{ }^{141} \mathrm{Pr},{ }^{146} \mathrm{Nd},{ }^{147} \mathrm{Sm},{ }^{153} \mathrm{Eu},{ }^{157} \mathrm{Gd},{ }^{159} \mathrm{~Tb}$, ${ }^{163} \mathrm{Dy},{ }^{165} \mathrm{Ho},{ }^{166} \mathrm{Er},{ }^{169} \mathrm{Tm},{ }^{172} \mathrm{Yb},{ }^{175} \mathrm{Lu},{ }^{178} \mathrm{Hf},{ }^{181} \mathrm{Ta},{ }^{208} \mathrm{~Pb}$, ${ }^{232} \mathrm{Th},{ }^{238} \mathrm{U}$. For each analysis, the gas blank was acquired for $30 \mathrm{~s}$ with no laser firing, followed by $90 \mathrm{~s}$ of ablation. Data were processed using the Glitter data reduction software (Van Achterberg, et al. 2001). GSD reference glass (UGSD of USGS) was used as external standard allowing the use of either ${ }^{44} \mathrm{Ca}$ or ${ }^{57} \mathrm{Fe}$ as internal standard, generating a self-consistent data set for plagioclase and olivine. Quality control checks were performed using the BCR2-G reference material at the beginning and end of the sequence, then compared to the reference published values (Sigmarsson et al. 2013). Repeated measurements of this secondary standard indicate that the accuracy is better than $10 \%$ relative (Table 1)

\section{Whole-rock chemistry}

A series of 100 whole-rock samples was analysed for major elements by X-ray fluorescence spectrometry with an ARL PERFORM'X 4200 (Rh X-ray tube) (University of Liège, Belgium) (Supplementary Table 1). Samples were manually crushed with a hammer into small blocks of maximum $5 \mathrm{~mm}$ and then powdered in agate ball mill mortars with a Fritsch Pulverisette. The loss on ignition was measured on $1 \mathrm{~g}$ of the sample powder heated at $1000{ }^{\circ} \mathrm{C}$ during two hours. An aliquot of the calcinated powder $(0.35 \mathrm{~g})$ was then mixed with lithium tetra-borate and meta-borate to enable the preparation of fused glass beads that were then analysed with the spectrometer. Raw data were corrected for background (Na, P) and for matrix effects using the Traill-Lachance method
(Lachance and Traill 1966). A collection of 47-66 international standards (mostly rock samples of basalts to granites, syenites, ultramafic and sedimentary rocks with a few minerals and two soils) were used for the calibration. This high number of standards enables a good distribution of the standards over the concentration range of all major elements and is necessary for the calculation of matrix correction. The accuracy of the method was estimated by repeat analyses of international standard BEN and an in-house standard and it is better than $\pm 5 \%$ for all major elements except $\mathrm{Na}_{2} \mathrm{O}( \pm$ $5.01 \%), \mathrm{P}_{2} \mathrm{O}_{5}( \pm 7.86 \%)$ and $\mathrm{TiO}_{2}( \pm 6.71 \%)$. Analytical precision (1) was estimated by analysing a group of in-house samples and is estimated to be better than $\pm 4 \%$ for all major elements except $\mathrm{Al}_{2} \mathrm{O}_{3}( \pm 4.8 \%)$ and $\mathrm{SiO}_{2}( \pm 4.84 \%)$.

Trace elements were analysed in the same set of wholerock samples except CL91 (plutonic basement) with a Thermo Scientific X-Series 2 ICP-MS (RMCA Tervuren, Belgium) equipped with a collision cell. The samples were put into solution by alkali fusion. International standards prepared with the same methodology as the samples as well as standard solutions were used for calibration. Additional details on sample preparation can be found in Vander Auwera et al. (2019). Repeat analyses of 12 standards were used to estimate the accuracy and precision that are respectively between \pm 2.0 and \pm 5.7 and between $\pm 1.5 \%$ and $\pm 5.2 \%$ (Namur et al. 2020) (Supplementary Table 1).

\section{Petrography}

\section{Mineralogy, mineral composition and textures}

Basaltic andesites and, to a lesser extent, andesites are the most frequent rock types in Calbuco. Andesites are found essentially as bombs or blocks with the exception of an andesitic lava flow from Unit 3 located on the southwestern side of the volcano. Sellés and Moreno (2011) reported two dacites from Units 2 (SCA077A) and 3 (SCA081). Only four basalts (CL119, CL120, CL $<$ Subscript $>2<$ /Subscript $>3$, CL $<$ Subscript $>2</$ Subscript $>4$ ), belonging to Unit 1, have been collected on the western flank. Basalts were previously not mentioned at Calbuco except for the Hueñuhueñu and Reloncavi strata that crop out east of the volcano (LopezEscobar et al. 1995). The major and trace element compositions of olivine-hosted melt inclusions (Montalbano 2018; Bechon et al., in prep) and the calculated trace element composition of the melt in equilibrium with troctolitic glomerocrysts (see below) both overlap the composition of these basalts supporting their attribution to the Calbuco magmatic system. The lavas are massive to vesicular, porphyritic with $\sim 25$ to 48 vol \% of macrocrysts (plagioclase, orthopyroxene, clinopyroxene, olivine, amphibole and magnetite) dispersed in a micro- to cryptocrystalline matrix. In order to 
Table 1 LA-ICPMS analyses (ppm) of olivine and plagioclase from CL149 troctolitic glomerocrysts

\begin{tabular}{|c|c|c|c|c|c|c|c|c|c|c|}
\hline \multicolumn{11}{|c|}{ Olivine } \\
\hline Point & $\mathrm{Pt} 2 / 5$ & $\mathrm{Pt} 2 / 6$ & Pt1/7 & $\mathrm{Pt} 1 / 8$ & Pt10/9 & Pt10/10 & $\mathrm{Pt5} / 11$ & $\mathrm{Pt5} / 12$ & $\mathrm{Pt} 3 / 13$ & $\mathrm{Pt} 3 / 14$ \\
\hline $\mathrm{K}$ & 7.3 & 0.5 & 2.9 & 38.1 & 2.2 & 2.2 & 1.0 & 1.8 & 7.4 & 2.1 \\
\hline Sc & 7.28 & 5.61 & 5.58 & 6.48 & 5.92 & 6.29 & 6.05 & 5.86 & 6.18 & 6.05 \\
\hline V & 8.4 & 8.3 & 8.4 & 10.7 & 7.3 & 8.1 & 7.7 & 9.9 & 9.3 & 9.7 \\
\hline $\mathrm{Cr}$ & 23 & 22 & 20 & 21 & 24 & 20 & 22 & 20 & 16 & 18 \\
\hline $\mathrm{Co}$ & 180 & 196 & 182 & 195 & 202 & 199 & 202 & 196 & 172 & 182 \\
\hline $\mathrm{Ni}$ & 87 & 94 & 107 & 109 & 116 & 98 & 95 & 95 & 89 & 95 \\
\hline $\mathrm{Zn}$ & 171 & 209 & 232 & 226 & 197 & 200 & 188 & 202 & 203 & 186 \\
\hline $\mathrm{Rb}$ & 0.05 & 0.01 & 0.01 & 0.08 & 0.01 & 0.01 & 0.01 & 0.01 & 0.02 & 0.01 \\
\hline $\mathrm{Sr}$ & 0.61 & 0.04 & 0.19 & 0.74 & 0.05 & 0.06 & 0.01 & 0.02 & 0.07 & 0.02 \\
\hline $\mathrm{Y}$ & 0.24 & 0.12 & 0.26 & 0.14 & 0.08 & 0.07 & 0.08 & 0.11 & 0.16 & 0.06 \\
\hline $\mathrm{Zr}$ & 0.24 & 0.35 & 0.04 & 0.27 & 0.23 & 0.07 & 1.38 & 0.86 & 0.16 & 0.08 \\
\hline $\mathrm{Nb}$ & 0.01 & 0.03 & 0.00 & 0.02 & 0.00 & 0.00 & 0.01 & 0.02 & 0.24 & 0.00 \\
\hline $\mathrm{Ba}$ & 0.46 & 0.02 & 0.08 & 0.61 & 0.03 & 0.07 & 0.01 & 0.02 & 0.14 & 0.02 \\
\hline $\mathrm{La}$ & 0.10 & 0.01 & 0.01 & 0.02 & 0.00 & 0.01 & 0.02 & 0.02 & 0.03 & 0.00 \\
\hline $\mathrm{Ce}$ & 0.17 & 0.10 & 0.01 & 0.08 & 0.00 & 0.01 & 0.01 & 0.04 & 0.03 & 0.01 \\
\hline $\operatorname{Pr}$ & 0.03 & 0.00 & 0.00 & 0.01 & 0.00 & 0.00 & 0.00 & 0.00 & 0.00 & 0.00 \\
\hline $\mathrm{Nd}$ & 0.12 & 0.04 & 0.03 & 0.04 & 0.01 & 0.01 & 0.01 & 0.04 & 0.03 & 0.02 \\
\hline $\mathrm{Sm}$ & 0.05 & 0.01 & 0.01 & 0.01 & 0.01 & 0.00 & 0.01 & 0.02 & 0.01 & 0.00 \\
\hline $\mathrm{Eu}$ & 0.01 & 0.01 & 0.01 & 0.00 & 0.00 & 0.00 & 0.01 & 0.03 & 0.01 & 0.00 \\
\hline $\mathrm{Yb}$ & 0.05 & 0.02 & 0.06 & 0.03 & 0.03 & 0.04 & 0.04 & 0.06 & 0.05 & 0.06 \\
\hline \multicolumn{11}{|c|}{ Plagioclase } \\
\hline Point & Pt11/16 & & Pt11/17 & $\mathrm{Pt} 7 / 22$ & $\mathrm{Pt} 7 / 23$ & Pt6/24 & Pt6/ 25 & $\mathrm{Pt} 4 / 26$ & $\mathrm{Pt} 4 / 27$ & $\mathrm{Pt} 9 / 28$ \\
\hline $\mathrm{K}$ & 244 & & 194 & 218 & 250 & 225 & 213 & 207 & 286 & 253 \\
\hline Sc & 0.45 & & 0.39 & 0.41 & 0.57 & 0.45 & 0.50 & 0.45 & 0.56 & 0.45 \\
\hline V & 1.5 & & 1.4 & 1.6 & 2.1 & 1.6 & 1.6 & 1.5 & 2.1 & 1.7 \\
\hline $\mathrm{Cr}$ & 3.0 & & 3.2 & 3.4 & 5.8 & 4.7 & 3.1 & 3.1 & 7.4 & 5.8 \\
\hline Co & 0.4 & & 0.4 & 0.4 & 0.6 & 0.4 & 0.4 & 0.4 & 0.8 & 0.5 \\
\hline $\mathrm{Ni}$ & 0.8 & & 0.7 & 1.8 & 1.2 & 0.9 & 0.8 & 1.0 & 1.5 & 1.0 \\
\hline $\mathrm{Zn}$ & 3.3 & & 2.6 & 7.6 & 5.7 & 3.8 & 3.2 & 6.8 & 10.2 & 5.9 \\
\hline $\mathrm{Rb}$ & 0.04 & & 0.01 & 0.04 & 0.09 & 0.02 & 0.01 & 0.04 & 0.11 & 0.04 \\
\hline $\mathrm{Sr}$ & 465 & & 451 & 471 & 483 & 481 & 481 & 482 & 479 & 489 \\
\hline $\mathrm{Y}$ & 0.14 & & 0.12 & 0.15 & 0.26 & 0.14 & 0.16 & 0.14 & 0.33 & 0.15 \\
\hline $\mathrm{Zr}$ & 0.42 & & $<$ & 0.29 & 1.68 & 0.45 & 0.42 & 0.15 & 0.21 & 0.20 \\
\hline $\mathrm{Nb}$ & 0.00 & & $<$ & 0.07 & 0.07 & 0.05 & 0.01 & 0.09 & 0.07 & 0.01 \\
\hline $\mathrm{Ba}$ & 12 & & 11 & 13 & 14 & 12 & 12 & 15 & 15 & 16 \\
\hline $\mathrm{La}$ & 0.40 & & 0.35 & 0.43 & 0.48 & 0.42 & 0.43 & 0.46 & 0.52 & 0.44 \\
\hline $\mathrm{Ce}$ & 0.76 & & 0.63 & 0.84 & 0.93 & 0.72 & 0.75 & 0.91 & 0.81 & 0.79 \\
\hline $\operatorname{Pr}$ & 0.08 & & 0.07 & 0.10 & 0.09 & 0.08 & 0.08 & 0.09 & 0.09 & 0.09 \\
\hline $\mathrm{Nd}$ & 0.38 & & 0.34 & 0.41 & 0.54 & 0.40 & 0.37 & 0.58 & 0.45 & 0.40 \\
\hline $\mathrm{Sm}$ & 0.08 & & 0.07 & 0.10 & 0.15 & 0.09 & 0.07 & 0.08 & 0.09 & 0.08 \\
\hline $\mathrm{Eu}$ & 0.21 & & 0.19 & 0.22 & 0.27 & 0.21 & 0.24 & 0.22 & 0.25 & 0.24 \\
\hline $\mathrm{Yb}$ & 0.01 & & 0.01 & 0.04 & 0.06 & 0.01 & 0.02 & 0.01 & 0.03 & 0.01 \\
\hline
\end{tabular}

avoid genetic terms, macrocryst and microcryst will refer to crystals that are respectively larger and smaller than $100 \mu \mathrm{m}$. Locally, some magnetite macrocrysts can be smaller than this threshold as observed by Namur et al. (2020) but still much larger than oxides in the fine-grained matrix. Glomerocryst designates a monomineralic or polymineralic assemblage of macrocrysts. Our petrographic observations agree with those previously described by Lopez-Escobar et al. 
(1992), Lopez-Escobar et al. (1995), Sellés and Moreno (2011), Romero et al. (2016), Arzilli et al. (2019), Morgado et al. (2019b) and Namur et al. (2020). There is a gradual evolution in the mineralogy from the basalts to the andesites: olivine and plagioclase are the sole macrocrysts in the least differentiated sample (basalt CL119), the proportion of olivine relics surrounded by a peritectical rim apparently decreases with increasing $\mathrm{SiO}_{2}$, augite macrocrysts are rare or absent in the basalts, abundant in the basaltic andesites and again less abundant in the andesites, amphibole has not been observed in the basalt and is much more abundant in the andesites than in the basaltic andesites.

Plagioclase is the dominant macrocryst. It occurs as isolated grains and in glomerocrysts. It is sub- to euhedral with a long axis length locally reaching $3 \mathrm{~mm}$ to $1 \mathrm{~cm}$ but generally ranging from 0.5 to $1 \mathrm{~mm}$ (Fig. 3 and Supplementary Fig. 1). Most plagioclase macrocrysts display euhedral An-rich cores surrounded by a more albitic rim of variable thickness $(25-100 \mu \mathrm{m})$ usually showing oscillatory zoning superimposed on normal zoning (Fig. 3a) (see Fig. 4 and Table 2 for a summary of macrocrysts composition). This rim is absent at the contact between touching plagioclase macrocrysts (Fig. 3b, d). The $\mathrm{FeO}$ content is rather constant in the An-rich core and appears to increase very slightly in the rim (Fig. 3a, b). This increase is probably not significant given the analytical scatter and the secondary fluorescence that may influence the analysis close to the crystal margin (Longhi et al. 1976). Rarely, the cores show embayments or even patchy textures likely resulting from partial dissolution of the initial crystal (Fig. 3c). The core of the plagioclase is usually free of inclusions (mineral inclusions and/or crystallized melt inclusions) but sieved, sieved-core (Fig. 3d) and sieved-ringed grains have been observed. Olivine $(100 \mu \mathrm{m}$ to $3 \mathrm{~mm}$ ) occurs as isolated grains or in glomerocrysts, it is normally zoned (Fig. 5a) (Table 2) except in two olivine grains where a reverse zoning has been observed, one in a basaltic andesite (CL43: Fo74-80 with Fo\# $=\mathrm{Mg} * 100 /\left(\mathrm{Mg}+\mathrm{Fe}_{\mathrm{t}}\right.$ ), Fig. 5b) and one in a pyroclast (CL51B: Fo76-79). Olivine has scarce inclusions (partly recrystallised melt inclusions and opaques) and is locally partially altered into iddingsite. It is generally surrounded either by a thin rim of orthopyroxene of variable grain size (microcrystalline to $200 \mu \mathrm{m}$ ) (Fig. 5a) or by a symplectite composed of orthopyroxene and magnetite (Fig. 5c). The olivine relic grains have lobate contours and locally display identical optical orientation. These textures result from a peritectic reaction between olivine and melt to produce orthopyroxene. The most magnesian olivine was found in a pyroclast sample (CL112A: $\mathrm{Fo}_{88}$ ) but olivine is usually $\mathrm{Fo}_{75-80}$ (Fig. 4). Augite macrocrysts can be up to $3 \mathrm{~mm}$ long. They are lacking in two basalts (CL119, CL120) and are more abundant in the basaltic andesites than in the andesites. Augite has a $\mathrm{Mg} \#(\mathrm{Mg} \#=\mathrm{Mg} * 100 /$ $\left(\mathrm{Mg}+\mathrm{Fe}_{\mathrm{t}}\right)$ ) ranging mostly from 68 to 78 (Fig. 4). It is unzoned (Fig. 5d) except for a few normally zoned (largest: Mg\#81-59) or reversely zoned (largest: Mg\#71-80) grains. Pigeonite $\left(\mathrm{Mg} \# 52-66\right.$ with $\left.\mathrm{Mg} \#=\mathrm{Mg} * 100 /\left(\mathrm{Mg}+\mathrm{Fe}_{\mathrm{t}}\right)\right)$ has locally been found surrounding olivine, orthopyroxene or augite (Fig. 5d). Enstatite macrocrysts are mostly present as sub- to euhedral prisms with slightly rounded extremities from $200 \mu \mathrm{m}$ to $1 \mathrm{~mm}$ and containing inclusions of plagioclase, magnetite and olivine. Enstatite is usually

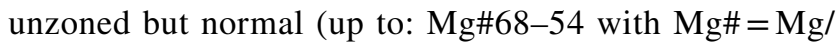
$\left(\mathrm{Mg}+\mathrm{Fe}_{\mathrm{t}}\right)$ ) and reverse (largest: $\mathrm{Mg \# 66-73)} \mathrm{zoning} \mathrm{have}$ been observed. Macrocrysts of magnetite are usually smaller than the other ones (100 to $500 \mu \mathrm{m})$. A few analyses reveal it is a titanomagnetite with a variable $\mathrm{TiO}_{2}$ content (Usp $\mathrm{Mt}_{98}$ to $\mathrm{Usp}_{40} \mathrm{Mt}_{60}$ ) probably resulting from ilmenite exsolution during subsolidus reequilibration. Amphibole is present in the four units of the volcano. It is absent in the basalts and rare in the basaltic andesites where it has been observed in a few blocks and bombs (CL $<$ Subscript $>2<1$ Subscript $>8$, CL $<$ Subscript $>3</$ Subscript $>6$, CL50, CL57, CL96, CL102, CL115) or lavas (CL01, CL16, CL18, CL19, CL117, CL123). It is more abundant in the andesitic bombs or blocks. Amphibole was mostly observed in bombs and blocks, probably because it was preserved by the fast ascent whereas in slowly ascending lavas the sluggish decompression enabled nearly complete breakdown of this mineral (Rutherford and Hill 1993). Amphibole is brown to pale brown and occurs either as isolated, large (10 $\mu \mathrm{m}$ to $17 \mathrm{~mm}$ ) sub- to euhedral crystals or locally in glomerocrysts (Fig. 5e, f). As isolated grains, amphibole partly or completely reacted into an assemblage dominated by small magnetite grains associated with olivine $\left(\mathrm{Fo}_{68}\right)$, augite $\left(\mathrm{Ens}_{40-48}\right.$ $\left.\mathrm{Wo}_{36-44}\right)$ and plagioclase $\left(\mathrm{An}_{56-62}\right)$. The grain size of these reaction rims can vary from fine-grained in the inner part to coarser grained in the outer part. In glomerocryts, amphibole is subhedral or more rarely poikilitic interstitial (CL50, CL123, CL57) with no reaction rim at the contact between amphibole grains (Fig. 5f). It occurs together with pyroxenes and magnetite, essentially as subhedral crystals except in CL96 where it formed small scattered grains surrounding the pyroxenes. Amphibole was never observed in contact with olivine. Amphibole macrocrysts contain scarce inclusions of mostly plagioclase or locally pyroxenes. Following the recommendations of Leake et al. (1997) and Leake et al. (2003), $\mathrm{Fe}^{3+}$ was calculated on the basis of 13 cations and accordingly, the amphiboles are magnesiohastingsitic or rarely edenitic (Supplementary Table 2). Based on the $\mathrm{Mg} \#\left(\mathrm{Mg} /\left(\mathrm{Mg}+\mathrm{Fe}^{2+}\right)\right)$, amphibole is either unzoned or normally zoned except in one macrocryst of CL<Subscript $>3<1$ Subscript $>5$ where the rim has a higher Mg\# (89) than the core $(85)$.

Glomerocrysts are common in the Calbuco lavas. Their composition ranges from norite to melanorite in the basalts and from anorthosite, pyroxenite, gabbro, gabbronorite to 

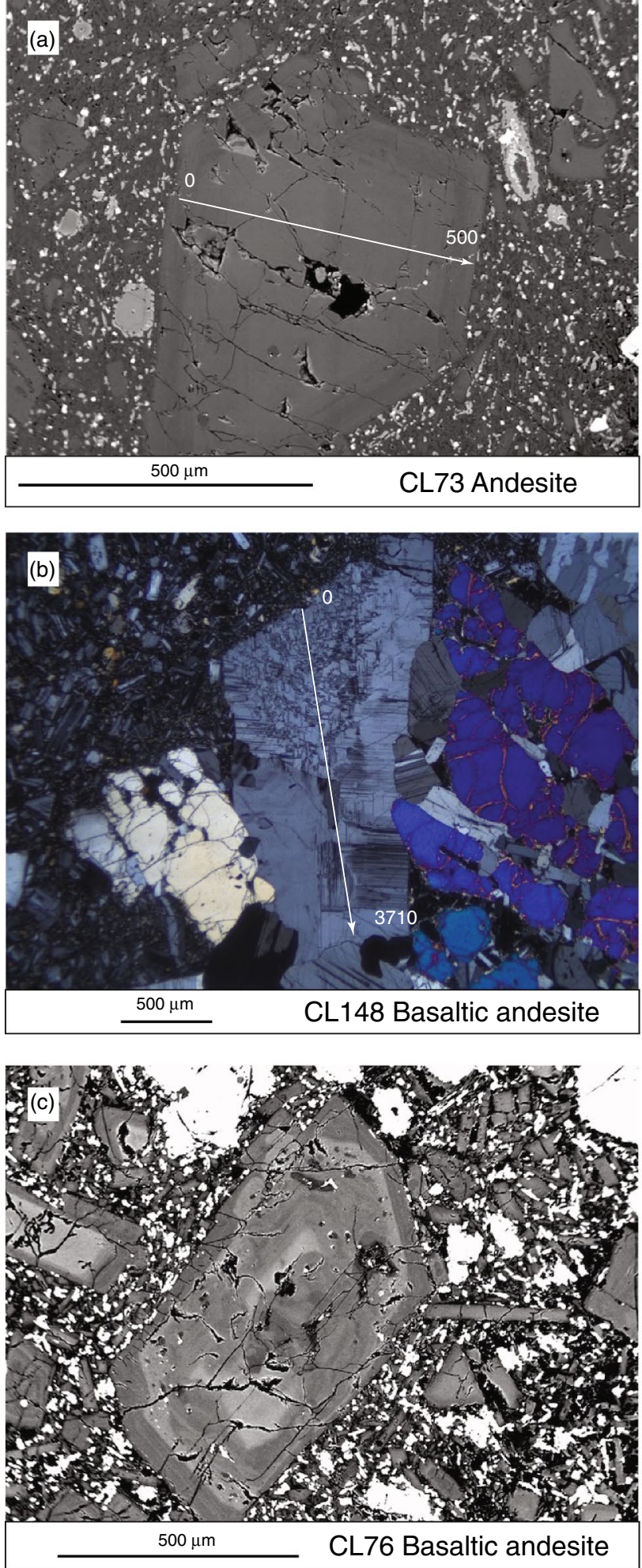

Fig. 3 a BSE image of a plagioclase macrocryst (sample CL73) displaying an An-rich core and a more albitic rim with oscillatory zoning. b Photomicrograph of a plagioclase macrocryst belonging to a troctolitic glomerocryst (CL148) displaying a very large An-rich core and a slightly more albitic rim at the contact with the matrix. Note that there is no albitic rim at the contact with the other plagioclase of the glomerocryst (cross polarized transmitted light). The trace of the profiles investigated by EPMA are shown by the white lines on the
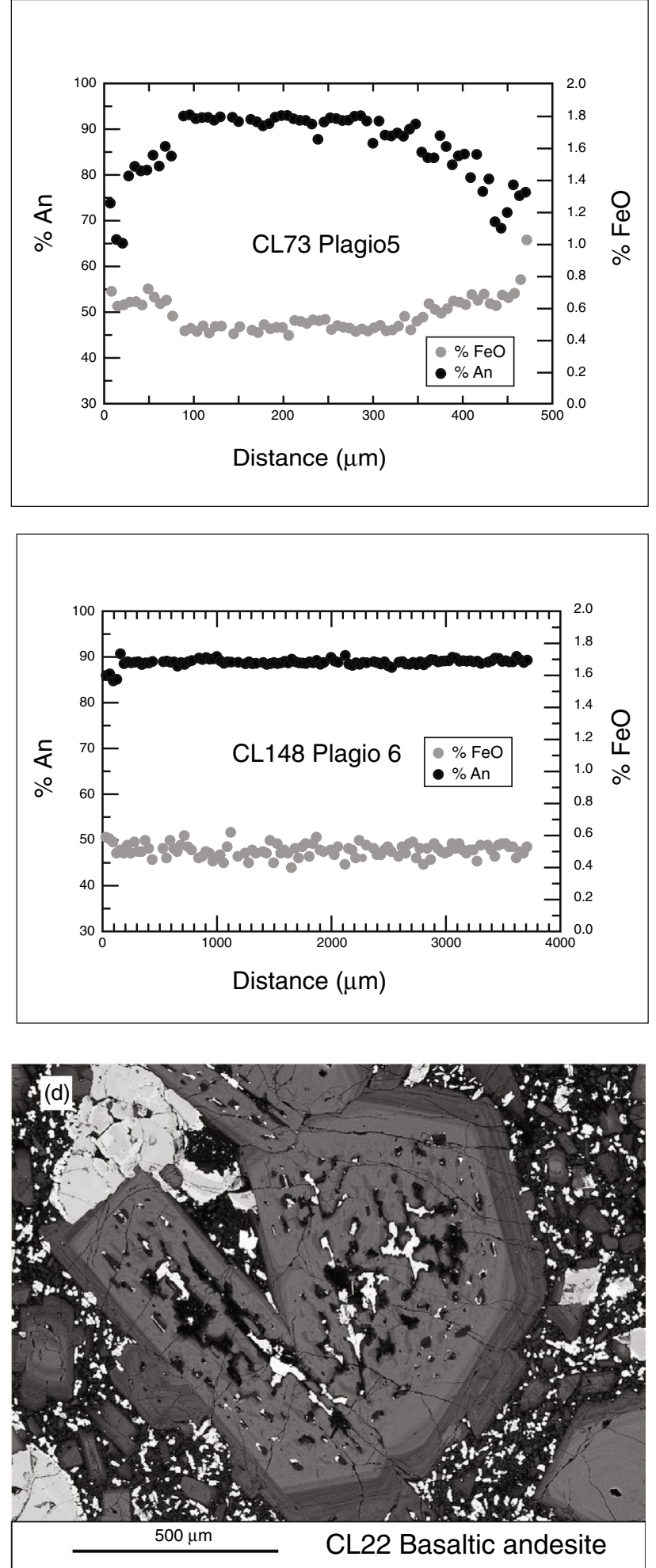

left panels of $\mathrm{a}$ and $\mathrm{b}$ and the $\%$ An (mole \%) and wt.\% FeO plots are on the right panels. $\mathbf{c}$ BSE image of a plagioclase macrocryst displaying patchy zoning in its core (sample CL76). d BSE image of touching plagioclase macrocrysts (sample $\mathrm{CL}<$ Subscript $>2</$ Subscript $>2$ ) with cores rich in inclusions and more albitic rims. Please note that the albitic rim is not present at the contact between the two macrocrysts 
Fig. 4 Mineral composition in the four units of Calbuco (basalts, basaltic andesites, andesites) $(\mathrm{Mg} \#=\mathrm{Mg} /$ $\left(\mathrm{Mg}+\mathrm{Fe}_{\mathrm{t}}\right)$ for olivine, pyroxenes and amphibole). Colours discriminate point analyses of core (blue), mantle (green) and rim (red). Grey is used for data acquired along profiles (plagioclase, olivine and pyroxenes) or when location is unspecified (amphibole). Note that the small arrows indicate a number of analyses that exceeds the range of the $y$ axis $\left(\mathrm{An}_{88-90}: 750\right.$ analyses, $\mathrm{Fo}_{74-76}: 284$ analyses, Cpx Mg\#74-76: 279 analyses) ( $n=$ number of analyses). Amphibole structural formulae calculated on a 23 oxygen basis using the "average $\mathrm{Fe}^{3+}$ " approach (Leake et al. 1997)
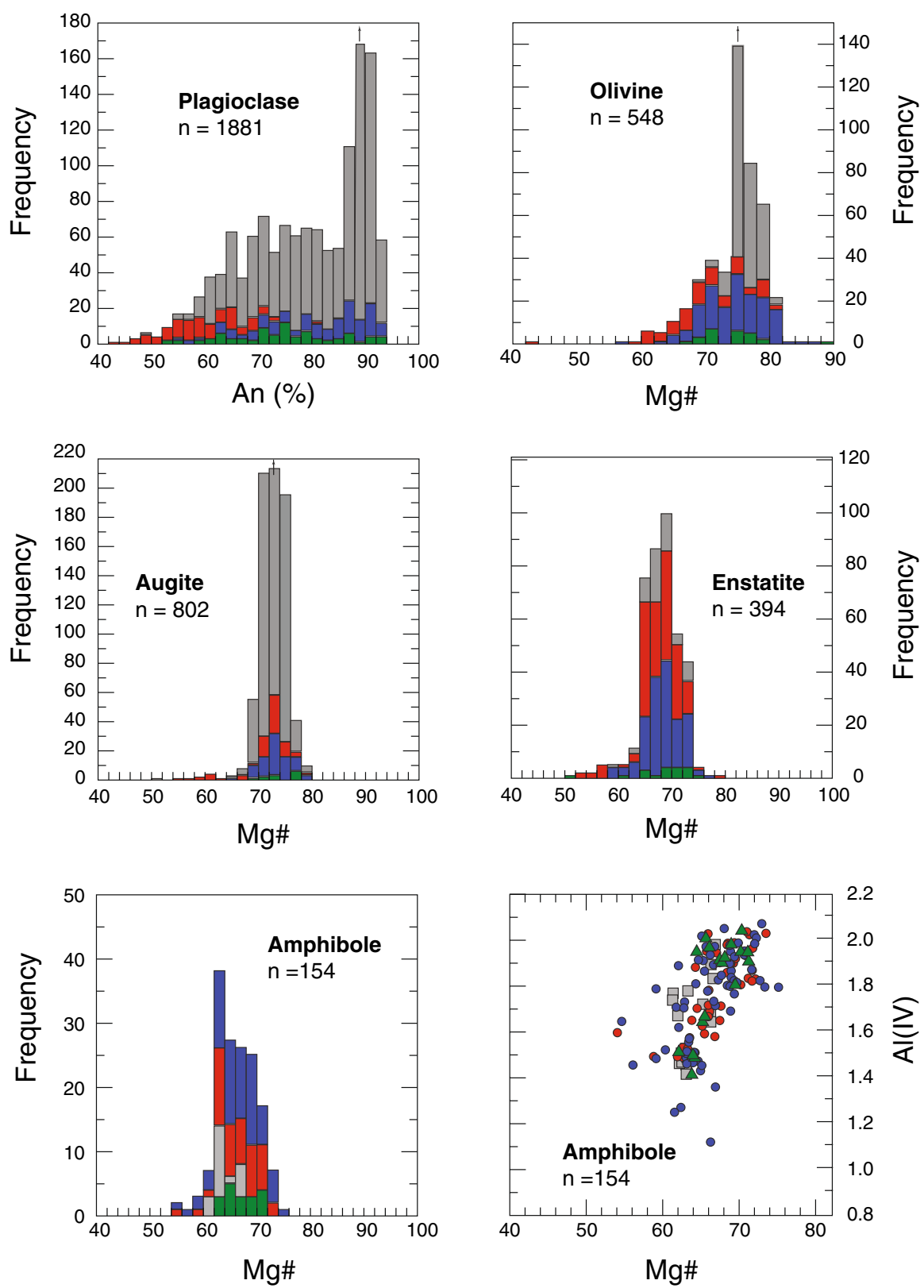

$\square$ Rim $\square$ Core $\square$ Mantle $\square$ Other

norite in the basaltic andesites. They mostly display hypidiomorphic textures with no clear layering. Two blocks (CL148, CL149) collected after the 2015 eruption contain remarkable centimetric troctolitic glomerocrysts where plagioclase is subhedral ( $250 \mu \mathrm{m}$ to $2.5 \mathrm{~mm})$, contains no mineral or melt inclusions and is unzoned (average $\mathrm{An}_{89}$ ), except for a thin $\operatorname{rim}(\sim 10 \mu \mathrm{m})$ where it is in contact with the host lava (down to $\mathrm{An}_{80}$ ) (Fig. 3b). In these glomerocrysts, olivine is found both as subhedral, frequently elongated crystals with a long axis up to $2.5 \mathrm{~mm}$ and rounded grains down to $250 \mu \mathrm{m}$. It displays a faint twinning and locally contains small grains of plagioclase but no melt inclusions. It is usually interstitial when in contact with plagioclase and slightly zoned $\left(\mathrm{Fo}_{77.3}\right.$ to $\mathrm{Fo}_{71.0}$ ) with an average composition of $\mathrm{Fo}_{75.5}$. In the glomerocrysts of CL149, the average trace element composition of olivine is $6.1 \mathrm{ppm} \mathrm{Sc}, 8.8 \mathrm{ppm} \mathrm{V}, 191 \mathrm{ppm} \mathrm{Co,} 98 \mathrm{ppm}$ $\mathrm{Ni}, 201 \mathrm{ppm} \mathrm{Zn}$ whereas the average trace element composition of plagioclase is $476 \mathrm{ppm} \mathrm{Sr,} 13.4 \mathrm{ppm} \mathrm{Ba} \mathrm{(Table} \mathrm{1).}$

The matrix is micro- to cryptocrystalline, usually finer grained in the blocks and bombs $(5 \mu \mathrm{m})$ than in the lavas (10 to $50 \mu \mathrm{m})$. It is made of abundant microcrysts of plagioclase (cores from $\mathrm{An}_{91}$ to $\mathrm{An}_{85}$, rims from $\mathrm{An}_{52}$ to 
Table 2 Summary of mineral compositional range

\begin{tabular}{|c|c|c|c|}
\hline Mineral & Rock type & Core & Rim \\
\hline \multirow[t]{4}{*}{ Plagioclase } & Basalt & An93-77 & An65-49 \\
\hline & Basaltic andesite & An94-56 & An70-45 \\
\hline & Andesite & An92-55 & An80-44 \\
\hline & Pyroclasts & & \\
\hline \multirow[t]{4}{*}{ Olivine } & Basalt & Fo78-65 & Fo70-60 \\
\hline & Basaltic andesite & Fo81-64 & Fo80-60 \\
\hline & Andesite & Fo77-64 & Fo75-44 \\
\hline & Pyroclasts & Fo88-74 & Fo88-65 \\
\hline \multirow[t]{4}{*}{ Augite } & Basalt & *Mg\#85-82 & $\mathrm{Mg \# 80}$ \\
\hline & Basaltic andesite & Mg\#84-67 & $\mathrm{Mg} \# 83-55$ \\
\hline & Andesite & Mg\#77-74 & $\mathrm{Mg} \# 77-75$ \\
\hline & Pyroclasts & $\mathrm{Mg \# 78-75}$ & $\mathrm{Mg} \# 78-75$ \\
\hline \multirow[t]{4}{*}{ Enstatite } & Basalt & $* \mathrm{Mg} \# 74-72$ & $\mathrm{Mg} \# 73-64$ \\
\hline & Basaltic andesite & Mg\#77-62 & $\mathrm{Mg} \# 78-53$ \\
\hline & Andesite & $\mathrm{Mg \# 70-58}$ & $\mathrm{Mg} \# 73-54$ \\
\hline & Pyroclasts & Mg\#72-66 & $\mathrm{Mg} \# 73-65$ \\
\hline \multirow[t]{4}{*}{ Amphibole } & Basalt & - & - \\
\hline & Basaltic andesite & *Mg\#97-70 & $\mathrm{Mg} \# 96-85$ \\
\hline & Andesite & Mg\#96-70 & Mg\#93-66 \\
\hline & Pyroclasts & Mg\#90-88 & Mg\#91-88 \\
\hline
\end{tabular}

${ }^{*} \mathrm{Mg} \#=\mathrm{Mg} /\left(\mathrm{Mg}+\mathrm{Fe}_{\mathrm{t}}\right)$ in olivine and pyroxenes whereas in amphibole, $\mathrm{Fe}^{3+}$ was taken into account following the recommendations of Leake et al. $(1997,2003)$ and thus $\mathrm{Mg} \#=\mathrm{Mg} /\left(\mathrm{Mg}+\mathrm{Fe}^{2+}\right)$. Only 5 analyses have been made in the amphibole from the pyroclasts

$\mathrm{An}_{43}$ ) that are euhedral, acicular to prismatic depending on the grain size, sub- to euhedral magnetite and prismatic to rounded grains of pyroxenes. Small interstitial glass pockets are locally preserved. Submicroscopic droplets of brown glass (not analysed), similar to those reported at $\mathrm{La}$ Picada (Vander Auwera et al. 2019), were observed in the interstitial glass of the basalts (not in CL119). In the basaltic andesites, they were noted only in plagioclase hosted melt inclusions and in the interstitial glass preserved in some glomerocrysts probably because the matrix usually has a higher crystallinity in this rock type.

As reported by Hickey-Vargas et al. (1995), enclaves from the basement are present in some flows. Among the enclaves analysed here, two are from the plutonic basement (CL91: diorite with 55.44 wt. \% $\mathrm{SiO}_{2}$ - CL145: granodiorite with 65.92 wt.\% $\mathrm{SiO}_{2}$ ) (Supplementary Table 1) and four (CL07, CL61, CL62, CL64) are very fine grained $(25-100 \mu \mathrm{m})$ granulites (42.49 to $52.04 \mathrm{wt} \% \mathrm{SiO}_{2}$ ) made of plagioclase, opaque, clinopyroxene and/or orthopyroxene usually displaying a well-defined schistosity and locally some compositional layering. Mingling relationships, as described for example at Quizapu (Higgins et al. 2015), have not been observed in the Calbuco lava flows.

\section{Point counting}

The proportions of macrocrysts (plagioclase, olivine, orthopyroxene, clinopyroxene, Ti-magnetite, amphibole) and groundmass were estimated by point counting with a PELCON Automatic Point Counter for 14 samples that are representative of the geochemical and textural variability observed at Calbuco. The steps along the $x$ - and $y$-axes were set at $0.5 \mathrm{~mm}$ and a total of $1500-2000$ points were counted for each thin section. Crystals smaller than $100 \mu \mathrm{m}$ (microcrysts) were considered as groundmass. The mass proportions on a vesicle-free basis were calculated using the following densities $\left(\mathrm{kg} / \mathrm{m}^{3}\right): 3200$ (amphibole), 5000 (titanomagnetite), 3200 (orthopyroxene, clinopyroxene), 3300 (olivine), 2700 (plagioclase, matrix). The mass fraction of macrocrysts range from $0.25-0.48$ with an average of 0.36 (Table 3). Plagioclase is the most abundant macrocryst $(0.20-0.41)$ followed by orthopyroxene $(0.01-0.09)$. Interestingly, the average matrix-free proportions of plagioclase and pyroxenes are similar in the lavas $(79.5 \% \mathrm{Pl}, 14.3 \% \mathrm{Px}$, this study) and in the 2015 pyroclasts $(78.8 \% \mathrm{Pl}, 19.4 \% \mathrm{Px}$ in Arzilli et al. (2019) and 70\% Pl and 25 to 30\% Px in Namur et al. (2020)) given that point counting (this study and Namur et al. (2020)) and textural analysis on BSE images using ImageJ software (Arzilli et al. 2019) may reflect small scale heterogeneities in individual thin sections. This similarity suggests that the fraction of macrocrysts is the same in effusive and explosive eruptions. As observed at La Picada (Vander Auwera et al. 2019), a few samples have a slightly higher ratio of plagioclase over ferromagnesian minerals than the rest of the dataset (Supplementary Fig. 2). These samples are also lower in $\mathrm{MgO}$ at the same $\mathrm{SiO}_{2}$ content (see "Results"). Both groups (Low- and High-MgO samples) have the same range of matrix proportion. The Low-MgO samples have been recognized in the four units of the volcano. These two groups were also discriminated at La Picada and interpreted as resulting from a slightly higher fractionation of olivine in the Low-MgO samples, maybe because of a slightly lower pressure of differentiation or/and higher melt $\mathrm{H}_{2} \mathrm{O}$ content as the olivine stability field expands when pressure decreases or melt $\mathrm{H}_{2} \mathrm{O}$ content increases (Sisson and Grove 1993; Longhi et al. 1999; Müntener et al. 2001; Ulmer et al. 2018; Boudreau, 2019).

\section{Results}

\section{Whole-rock major and trace element composition}

The geochemical dataset includes our samples and data from the literature (Lopez-Escobar et al. 1992, 1995; Sellés and Moreno 2011; Castruccio et al. 2016; Arzilli et al. 2019; Namur et al. 2020). Data from Castruccio et al. (2016), 

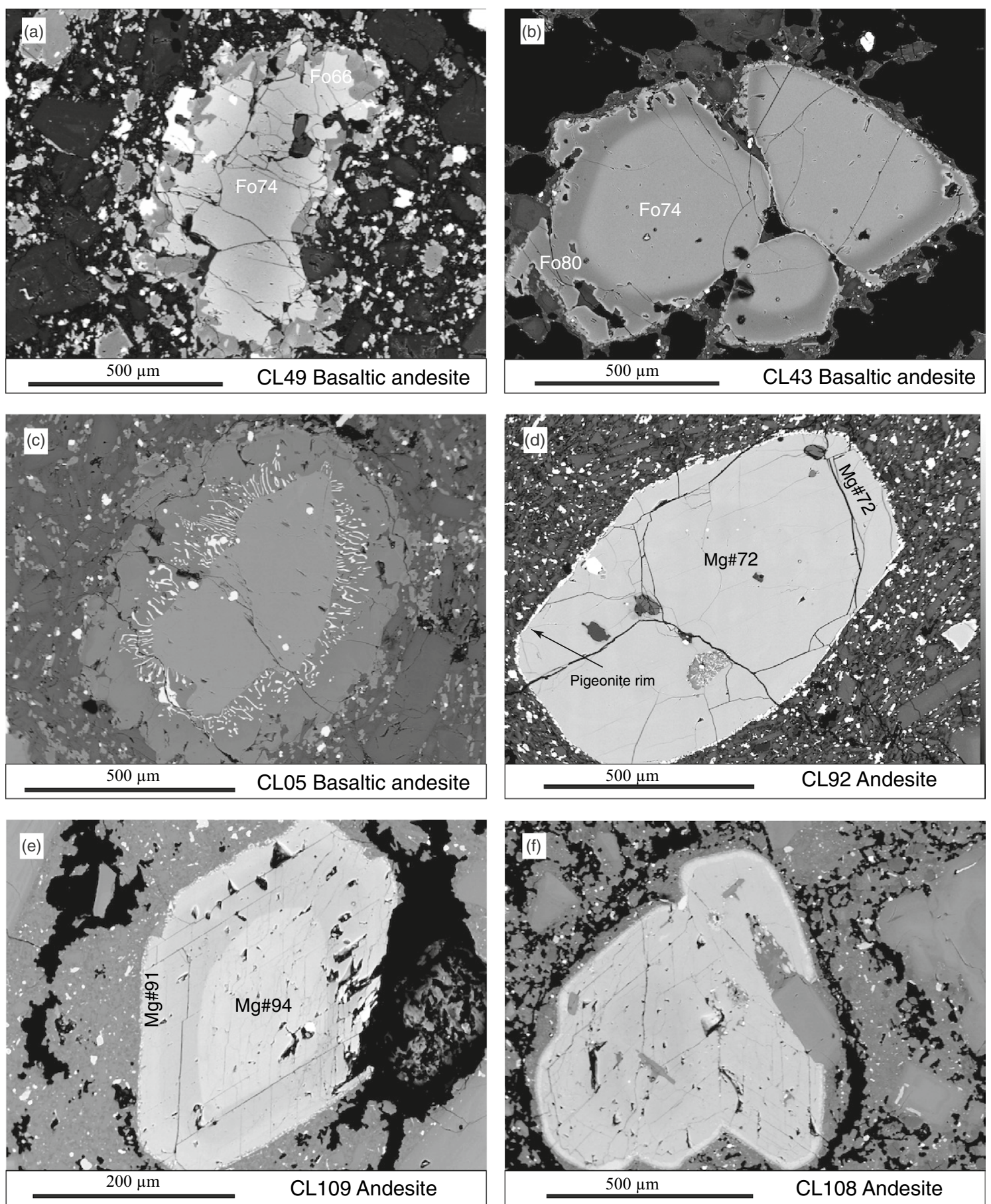

Fig. 5 BSE images. Olivine macrocrysts displaying a normal zoning and surrounded by a rim of orthopyroxene (basaltic andesite CL49) (a), a reverse zoning (basaltic andesite CL43) (b) or surrounded by a rim of symplectite made of orthopyroxene and magnetite (basaltic

Arzilli et al. (2019) and Namur et al. (2020) are for the April 2015 eruption only. In the geochemical plots, we have discriminated the different types of samples: lavas, pyroclasts, bombs and blocks. Analyses were recalculated to 100 wt. \% on a volatile free basis with total $\mathrm{Fe}$ as $\mathrm{FeO}_{\mathrm{t}}$. andesite CL05) (c). d Unzoned augite macrocryst surrounded by a very thin rim of pigeonite (andesite CL92). e Normally zoned amphibole macrocryst in andesite CL109. f Glomerocryst of amphibole with a reaction rim at the contact with the matrix (andesite CL108)

In a total alkali silica (TAS) diagram, samples from Calbuco plot in the subalkaline domain and range from basalts to dacites, basaltic andesites being dominant followed by andesites (Fig. 6a). Dacites are separated from the most evolved andesites by a Daly gap (61.87-64.75 wt. \% $\left.\mathrm{SiO}_{2}\right)$. 
Table 3 Raw point counting data and mass fractions for samples of Calbuco

\begin{tabular}{|c|c|c|c|c|c|c|c|c|}
\hline & Sample \# & CL119 & CL02* & CL03 & CL05 & CL123* & CL73** & CL76** \\
\hline & Rock type & Basalt & B. And & & & & & \\
\hline \multirow[t]{7}{*}{ Raw counts } & $\mathrm{gm}$ & 830 & 1350 & 1201 & 971 & 1336 & 1095 & 935 \\
\hline & $\mathrm{Pl}$ & 663 & 739 & 729 & 446 & 638 & 310 & 489 \\
\hline & $\mathrm{Ol}$ & 95 & 12 & 12 & 10 & 23 & 2.5 & 7 \\
\hline & Cpx & & 29 & 1 & 32 & 23 & 28 & 22 \\
\hline & Opx & & 29 & 52 & 32 & 119 & 47 & 41 \\
\hline & Mag & & 8 & 5 & 9 & 26 & 18 & 8 \\
\hline & Amp & & & & & 4 & & \\
\hline \multirow{8}{*}{$\begin{array}{l}\text { Mass fractions } \\
\text { (wt.\%) }\end{array}$} & $\mathrm{gm}$ & 52 & 61 & 60 & 64 & 60 & 72 & 61 \\
\hline & $\mathrm{Pl}$ & 41 & 34 & 36 & 29 & 29 & 20 & 32 \\
\hline & $\mathrm{Ol}$ & 7 & 0.7 & 0.7 & 0.8 & 1.3 & 0.2 & 0.5 \\
\hline & Cpx & & 1.7 & 0.1 & 2.5 & 1.3 & 2.2 & 1.7 \\
\hline & Opx & & 1.7 & 3.1 & 2.5 & 6.4 & 3.6 & 3.2 \\
\hline & Mag & & 0.7 & 0.5 & 1.1 & 2.3 & 2.1 & 1.0 \\
\hline & Amp & & & & & & & \\
\hline & macro & 48 & 39 & 40 & 36 & 40 & 28 & 39 \\
\hline \multirow{9}{*}{$\begin{array}{l}\text { Mass fractions } \\
\text { among macro } \\
\text { (wt.\%) }\end{array}$} & $\mathrm{Pl}$ & 85 & 88 & 89 & 81 & 72 & 71 & 84 \\
\hline & $\mathrm{Ol}$ & 15 & 1.7 & 1.8 & 2.2 & 3.3 & 0.7 & 1.4 \\
\hline & Cpx & & 4.4 & 0.1 & 6.9 & 3.1 & 7.7 & 4.4 \\
\hline & Opx & & 4.4 & 7.6 & 6.9 & 16 & 13 & 8.2 \\
\hline & Mag & & 1.8 & 1.1 & 3.0 & 5.7 & 7.4 & 2.5 \\
\hline & Amp & & & & & 0.4 & & \\
\hline & $\mathrm{WR} \mathrm{SiO}_{2}$ & 51.25 & 54.21 & 54.23 & 54.89 & 55.75 & 57.1 & 55.32 \\
\hline & Sample \# & CL79 & CL81 & $\mathrm{KAL}_{2} \mathrm{OA}$ & $\mathrm{CL}_{3} 4$ & CL40 & CL92** & CL94 \\
\hline & Rock type & B. And & & & And & & & \\
\hline \multirow[t]{7}{*}{ Raw counts } & $\mathrm{gm}$ & 1071 & 978 & 915 & 981 & 1023 & 1301 & 1511 \\
\hline & $\mathrm{Pl}$ & 330 & 443 & 429 & 412 & 360 & 416 & 449 \\
\hline & $\mathrm{Ol}$ & 8 & 7 & 5 & 0 & 0 & 0 & 0 \\
\hline & Cpx & 16 & 24 & 17 & 6 & 1 & 3 & 6 \\
\hline & Opx & 63 & 37 & 111 & 68 & 62 & 26 & 27 \\
\hline & Mag & 12 & 11 & 23 & 18 & 13 & 5 & 7 \\
\hline & Amp & & & & 15 & 41 & & \\
\hline \multirow{8}{*}{$\begin{array}{l}\text { Mass fractions } \\
\text { (wt.\%) }\end{array}$} & $\mathrm{gm}$ & 70 & 64 & 59 & 64 & 67 & 74 & 75 \\
\hline & $\mathrm{Pl}$ & 22 & 29 & 28 & 27 & 24 & 24 & 22 \\
\hline & $\mathrm{Ol}$ & 0.6 & 0.6 & 0.4 & 0.0 & 0.0 & 0.0 & 0.0 \\
\hline & Cpx & 1.2 & 1.9 & 1.3 & 0.5 & 0.1 & 0.2 & 0.4 \\
\hline & Opx & 4.9 & 2.9 & 8.5 & 5.3 & 4.8 & 1.7 & 1.6 \\
\hline & Mag & 1.5 & 1.3 & 2.8 & 2.2 & 1.6 & 0.5 & 0.6 \\
\hline & Amp & & & & 1.2 & 3.2 & & \\
\hline & macro & 30 & 36 & 41 & 36 & 33 & 26 & 25 \\
\hline \multirow{7}{*}{$\begin{array}{l}\text { Mass fractions } \\
\text { among macro } \\
\text { (wt.\%) }\end{array}$} & Pl & 72 & 81 & 68 & 75 & 71 & 91 & 90 \\
\hline & $\mathrm{Ol}$ & 2.1 & 1.6 & 1.0 & 0.0 & 0.0 & 0.0 & 0.0 \\
\hline & Cpx & 4.2 & 5.2 & 3.2 & 1.3 & 0.2 & 0.7 & 1.4 \\
\hline & Opx & 16 & 8.1 & 21 & 15 & 14 & 6.7 & 6.4 \\
\hline & Mag & 4.9 & 3.7 & 6.8 & 6.1 & 4.7 & 1.8 & 2.6 \\
\hline & Amp & & & & 3.2 & 9.6 & & \\
\hline & WR $\mathrm{SiO}_{2}$ & & 55.25 & 55.95 & 60.51 & 61.23 & 60.41 & 60.43 \\
\hline
\end{tabular}

gm groundmass, macro macrocryst

Counting repeated three times $(*)$ or twice $(* *)$ 

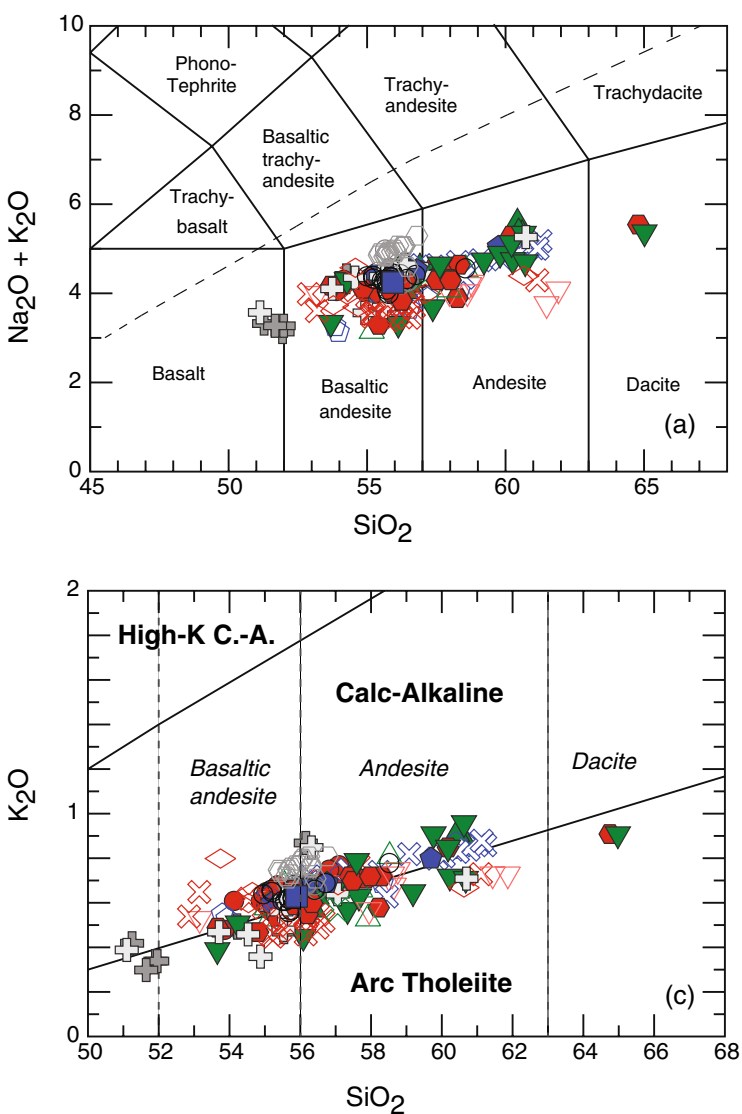

Fig. 6 Geochemical classification diagrams. Pyroclasts, bombs and blocks are shown with open symbols and lavas, with filled symbols. Different colors are used for the different units: 1 (grey), 2 (green), 3 (red), 4 (blue). a TAS diagram (line between alkaline and subalkaline fields is from Irvine and Baragar (1971) (wt. \%). b AFM diagram (line between tholeiitic and calc-alkaline fields is from Irvine

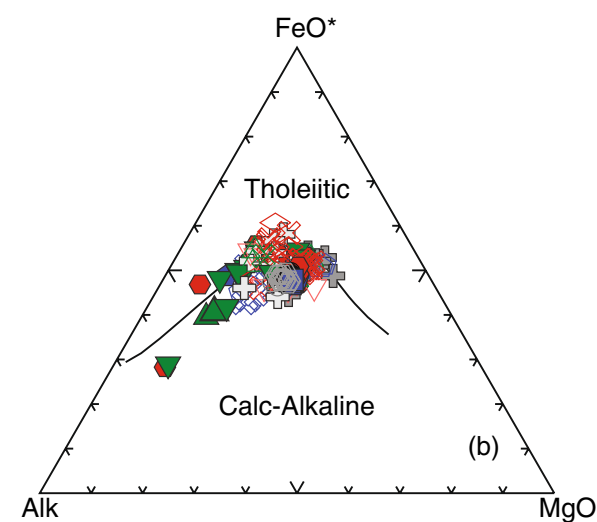

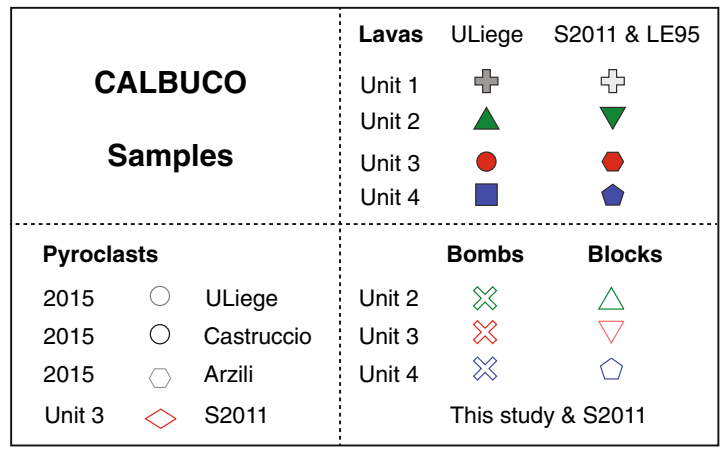

and Baragar (1971)). c $\mathrm{K}_{2} \mathrm{O}$ vs. $\mathrm{SiO}_{2}$ diagram (limits from Peccerillo and Taylor (1976)). Data from Arzilli et al. (2019), Castruccio et al. (2016), Lopez-Escobar et al. (1995) (LE95), Sellés and Moreno (2011) (S2011) and this study (wt. \%). Analyses recalculated to 100 wt. $\%$ on a volatile free basis with total $\mathrm{Fe}$ as $\mathrm{FeO}_{\mathrm{t}}$

and Moreno (2011) but also a few from our dataset) display lower $\mathrm{MgO}$ content at a given $\mathrm{SiO}_{2}$ than the rest of the samples (about 2 wt. \% lower at 56 wt. \% $\mathrm{SiO}_{2}$ ). This difference results from lower $\mathrm{MgO}$ rather than higher $\mathrm{SiO}_{2}$ content because single trends are observed for all other Harker diagrams with $\mathrm{SiO}_{2}$ as the differentiation index (Vander Auwera et al. 2019). LILE (Rb, Ba), HFSE (Zr, Hf, Nb, $\mathrm{Ta}$ ) as well as LREE increase whereas transition elements (Ni, Cr, V, Sc) decrease during differentiation (Fig. 8). Contrary to the LREE (La, Ce, Pr), the MREE (Nd, Eu, Sm) and HREE ( $\mathrm{Gd}$ to $\mathrm{Yb}$ ) remain rather constant after a minor increase in the compositional range from 51 to $54 \mathrm{wt}$. \% $\mathrm{SiO}_{2}$ (Fig. 8). The basalts display nearly flat REE patterns with no significant Eu anomaly $\left(\left(\mathrm{Eu} / \mathrm{Eu}^{*}\right)_{N}=1.03-1.08\right.$ and $(\mathrm{La} / \mathrm{Yb})_{N}=1.37-1.76$ : Supplementary Table 1) and spiderdiagrams typical of arc magmas with enrichment in LILE, $\mathrm{Pb}$ and $\mathrm{Sr}$ as well as depletions in $\mathrm{Nb}$ and $\mathrm{Ta}$ compared to N-MORBs (Supplementary Fig. 4). Samples from Calbuco As observed at La Picada, some samples (mostly from Sellés 

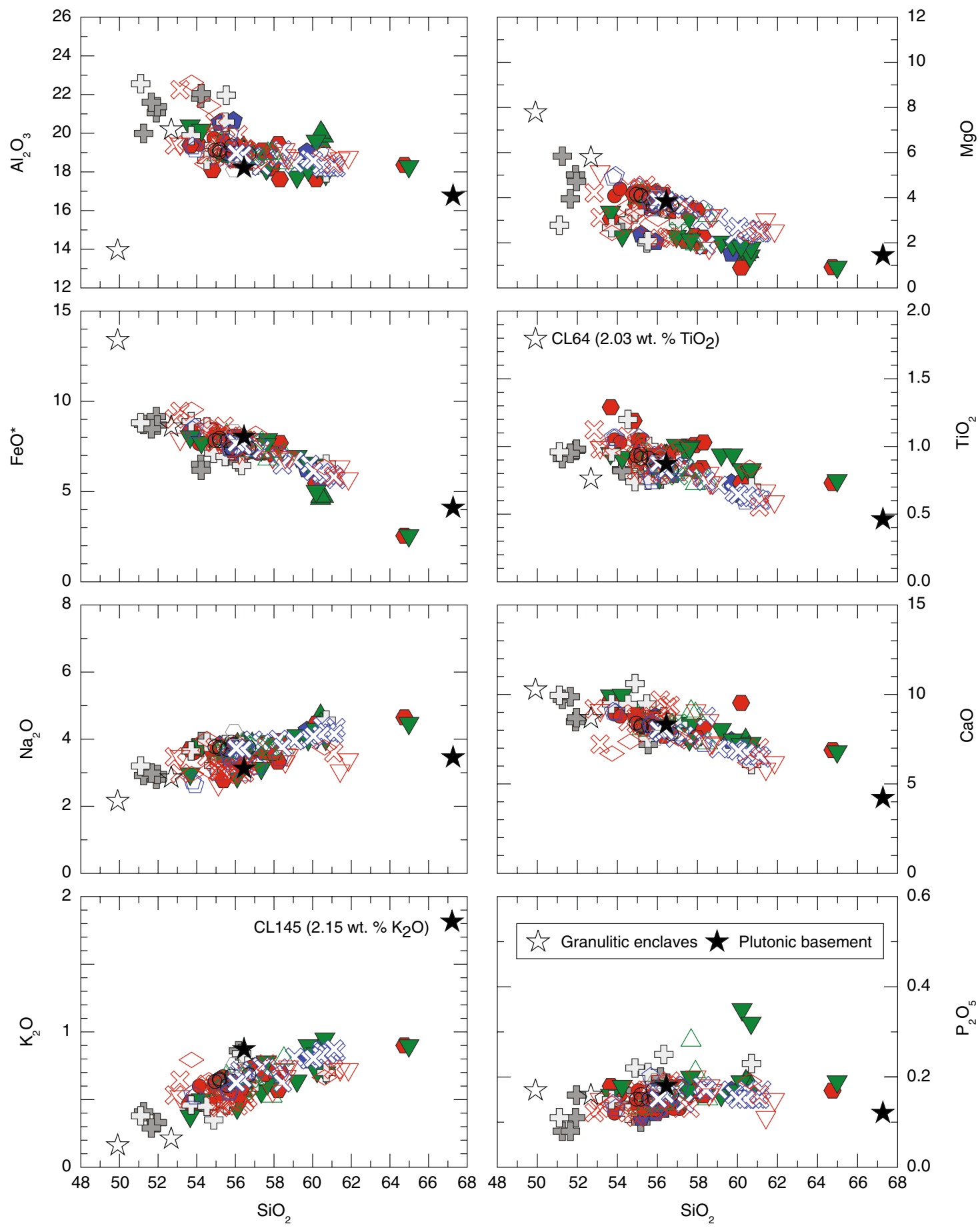

Fig. 7 Major element Harker diagrams of the Calbuco samples (wt. $\%$ ). Samples from effusive and explosive eruptions are discriminated. Analyses recalculated to 100 wt. \% on a volatile free basis with total $\mathrm{Fe}$ as $\mathrm{FeO}_{\mathrm{t}}$. Data from Arzilli et al. (2019), Castruccio et al. (2016),

Lopez-Escobar et al. (1995) and Sellés and Moreno (2011). Same symbols as in Fig. 6, open stars are the granulitic enclaves and filled stars are the basement plutonic samples

display higher $(\mathrm{Ba} / \mathrm{Nb})_{N}$ (normalized to $\mathrm{C} 1$ chondrite of Sun and McDonough (1989)), $(\mathrm{La} / \mathrm{Nb})_{N}$ and $(\mathrm{Sr} / \mathrm{Nb})_{N}$ than South Atlantic MORB and partly overlap the field of the Chile

trench sediments in $(\mathrm{Ce} / \mathrm{Pb})_{N}$ and $(\mathrm{Nb} / \mathrm{U})_{N}$ (Supplementary Fig. 4). 

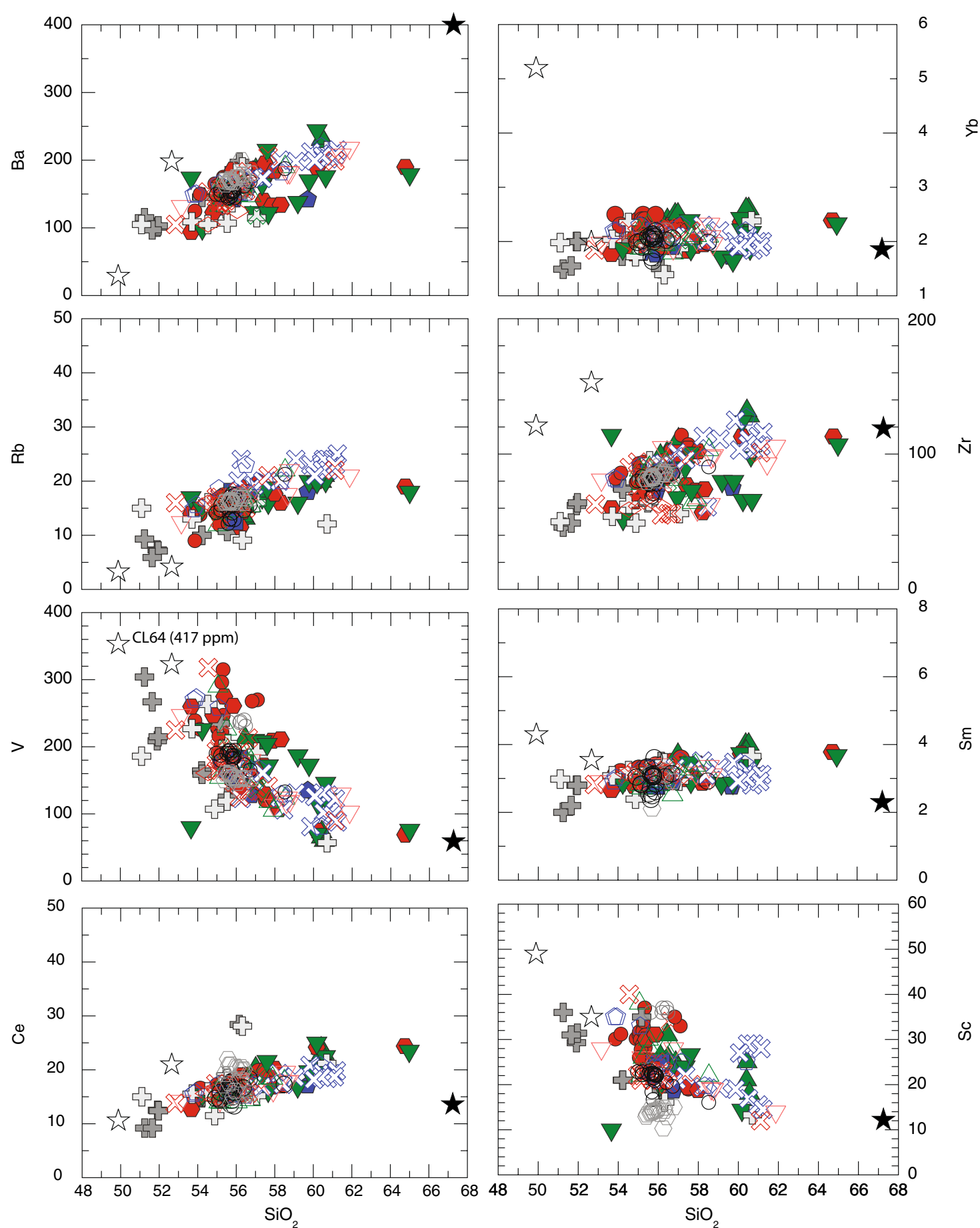

Fig. 8 Plots summarizing the trace element composition (Ba, Rb, V, Ce, Yb, Zr, Sm, Sc) of the Calbuco samples. Data from Arzilli et al. (2019), Castruccio et al. (2016), Lopez-Escobar et al. (1995) and Sellés and Moreno (2011). Same symbols as in Figs. 6 and 7

We used the multiple regressions of Humphreys et al. (2019) (Eqs. 1 and 4 respectively for $\mathrm{SiO}_{2}$ and $\mathrm{TiO}_{2}$ ) adapted from Zhang et al. (2017) to calculate the major element composition of the melts in equilibrium with amphibole (AEMs) (Fig. 9). The AEMs overlap the basaltic andesite and andesite differentiation trend and range from 55.05 to
76.8 wt. $\% \mathrm{SiO}_{2}$ (scale up to 68 wt. $\% \mathrm{SiO}_{2}$ in Fig. 9) which is in relatively good agreement with petrographic observations as amphibole is present in samples ranging from 54.89 (CL05) to 61.23 (CL40) wt.\% $\mathrm{SiO}_{2}$. Moreover, we note that the AEMs overlap the WR compositional gap suggesting that intermediate liquid composition did exist in the Calbuco 

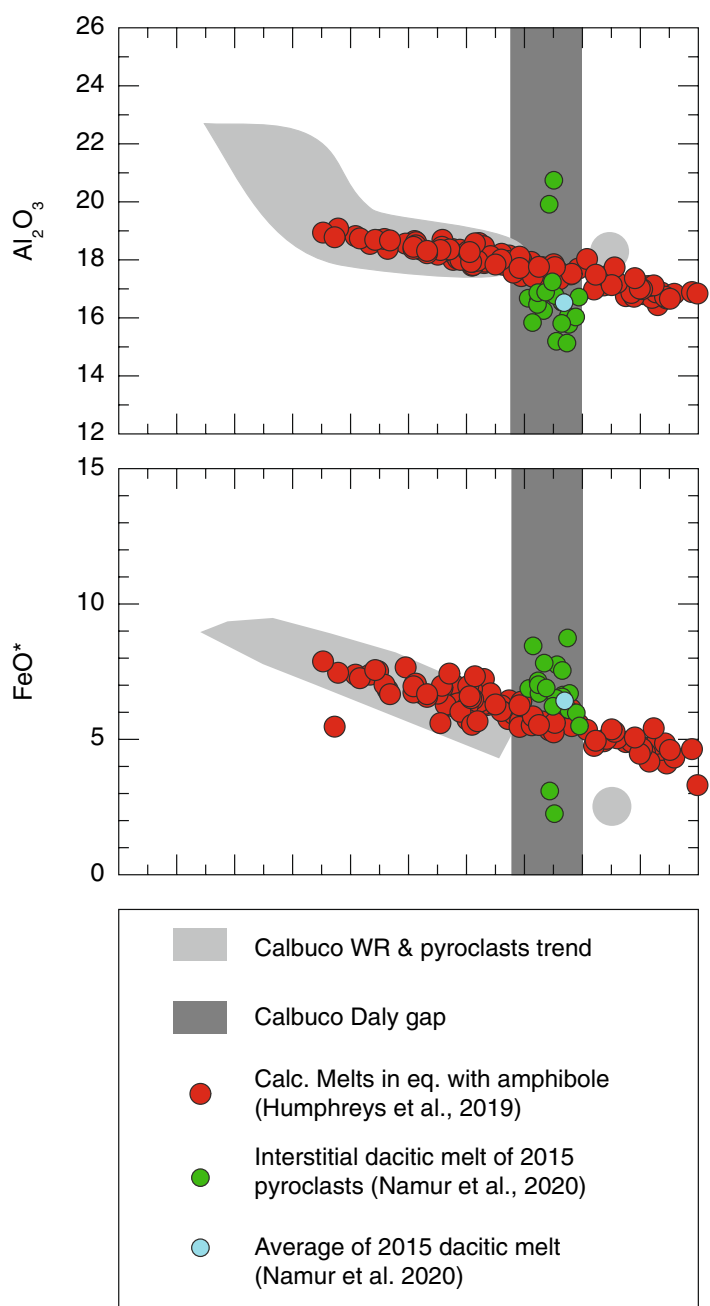

Fig. 9 Plots comparing the major element composition of the Calbuco samples (grey field) with the composition of the melts in equilibrium with amphibole (AEMs) calculated with the multiple regressions of Humphreys et al. (2019) (Eqs. 1 and 4 respectively for $\mathrm{SiO}_{2}$

magma storage region. Interestingly, the composition of the interstitial glass analysed by Namur et al. (2020) in the Calbuco 2015 pyroclasts also plot in the Daly gap (Fig. 9) further supporting this conclusion.

\section{Magma storage conditions}

Using various geothermobarometers, the pre-eruptive conditions of the 2015 eruption have been quantified by Arzilli et al. (2019) (230-320 MPa, 900-950 $\left.{ }^{\circ} \mathrm{C}\right)$, Morgado et al. (2019b) (150-470 MPa, 882-1019 ${ }^{\circ} \mathrm{C}$ ) and Namur et al. (2020) (200-320 MPa, 898-1160 ${ }^{\circ} \mathrm{C}$ ). Their results indicate a shallow depth (150-470 MPa) for the main storage region and a lower crystallization temperature for amphibole than for pyroxene (Morgado et al. 2019b; Namur et al. 2020). The
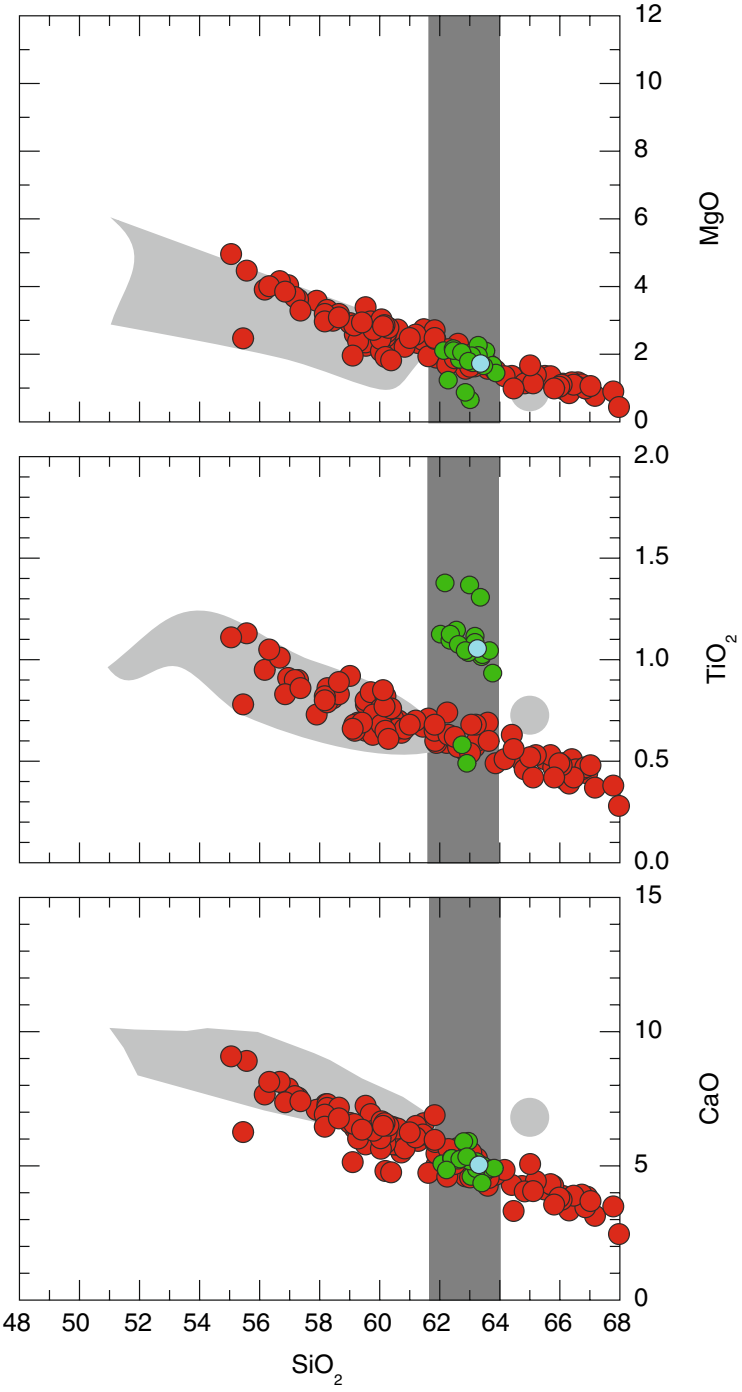

and $\mathrm{TiO}_{2}$ ) (wt. \%). The composition of the dacitic interstitial melt analysed by Namur et al. (2020) in the 2015 pyroclasts as well as the position of the Daly gap (dark grey field) are also shown

geothermobarometers (clinopyroxene-melt, clinopyroxene only, orthopyroxene-clinopyroxene, amphibole-melt equilibria) used in this study were applied to the different units of the volcano and confirm the 2015 conditions (Fig. 10 and Supplementary Figs. 5-8).

The occurrence of amphibole in samples ranging in composition from 54.89 to 61.23 wt. $\% \mathrm{SiO}_{2}$ indicates a minimum of $5.5 \mathrm{wt} \% \mathrm{H}_{2} \mathrm{O}$ in the equilibrium melt (54 wt. \% $\mathrm{SiO}_{2}$ ) at pressures in the interval 200-400 MPa (Sisson and Grove 1993; Moore and Carmichael 1998; Pichavant et al. 2002; Barclay and Carmichael 2004; Parat et al. 2014). It will be shown below that the fraction of residual liquid is close to 0.5 at about 54 wt. $\% \mathrm{SiO}_{2}$. Considering $\mathrm{H}_{2} \mathrm{O}$ as an incompatible element (even when amphibole is a fractionating phase, see "Discussion") and a process of fractional 


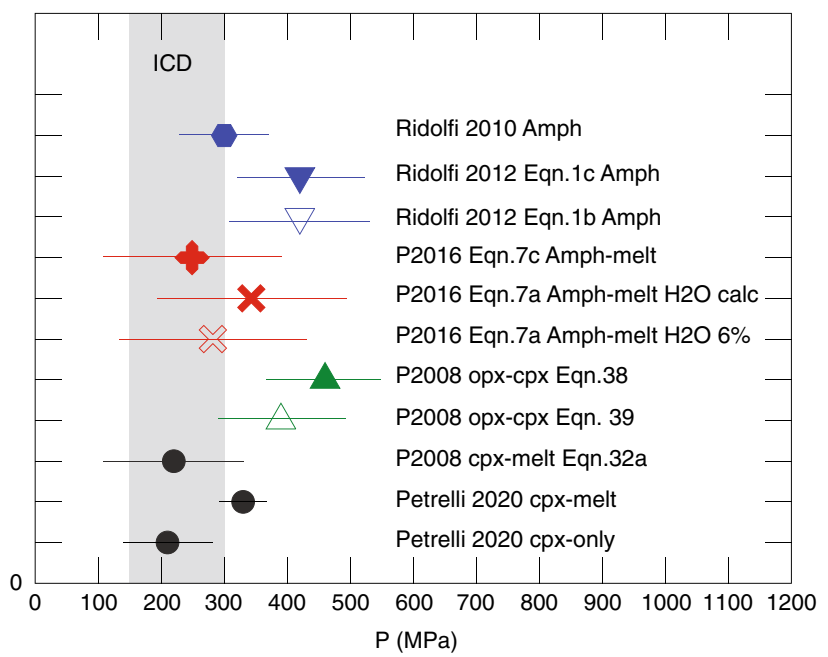

Fig. 10 Plot summarizing pressure estimates with different thermobarometers $(\mathrm{P} 2016=$ Putirka 2016; P2008 = Putirka 2008). ICD = Intracrustal discontinuity of Tassara and Echaurren (2012) and Tassara et al. (2006)

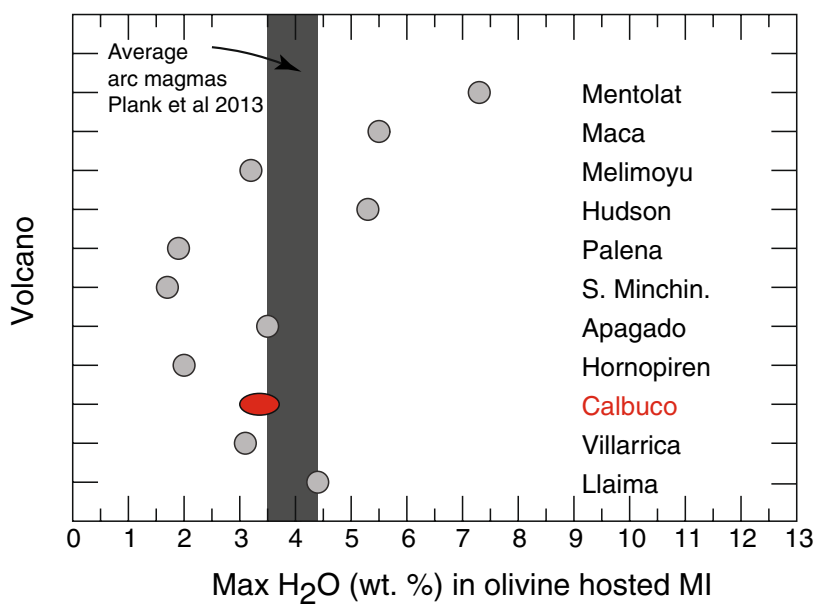

Fig. 11 Maximum $\mathrm{H}_{2} \mathrm{O}$ content (wt.\%) measured in olivine-hosted melt inclusions from volcanoes of the Southern Volcanic Zone (Llaima: Bouvet de Maisonneuve et al. (2012); Villarrica: Pioli et al. (2015); Hornopiren, Apagado, South Minchinmavida and Palena: Watt et al. (2013); Hudson, Melimoyu, Maca and Mentolat: Weller and Stern (2018)). The average $3.9 \pm 0.4$ wt. $\% \mathrm{H}_{2} \mathrm{O}$ of arc magmas from Plank et al. (2013) is also shown (grey field)

crystallization, the Rayleigh distillation law $\left(C_{\mathrm{L}}=C_{0} / f\right.$ as $\left.D_{\mathrm{H} 2 \mathrm{O}}=0\right)$ gives an $\mathrm{H}_{2} \mathrm{O}$ content of about 3 wt. $\%$ in the basaltic parent magma. This estimation is within the range of $\mathrm{H}_{2} \mathrm{O}$ content measured in melt inclusions (2.06-6.73 wt. \% $\mathrm{H}_{2} \mathrm{O}$ ) hosted in plagioclase, orthopyroxene and clinopyroxene from the 2015 eruption scoriae (58-64 wt. \% $\mathrm{SiO}_{2}$ ) (Arzilli et al. 2019), and more particularly, in melt inclusions hosted in olivine from the different units of Calbuco (1.46-4.12 wt. $\% \mathrm{H}_{2} \mathrm{O}$, average $=3.0$ wt. $\% \mathrm{H}_{2} \mathrm{O}$ ) (Montalbano 2018;
Bechon et al., in prep). It is also comparable to the maximum $\mathrm{H}_{2} \mathrm{O}$ content measured in olivine-hosted melt inclusions from other volcanoes of the SVZ (Fig. 11). The presence of An-rich cores in plagioclase could witness a higher $\mathrm{H}_{2} \mathrm{O}$ content. Indeed, Pichavant et al. (2002) indicated that $\mathrm{An}_{89-90}$ crystallizes in a basaltic andesite with 8 wt. $\% \mathrm{H}_{2} \mathrm{O}$ at $400 \mathrm{MPa}$. However, anorthite was in equilibrium with amphibole \pm magnetite, olivine being absent whereas in the troctolitic glomerocrysts (CL148, CL149), anorthite is in equilibrium with olivine only (Fig. 3b). Sisson and Grove (1993) obtained $\mathrm{An}_{93-91}$ together with olivine $+\mathrm{Cpx} \pm$ spinel in two basalts at $200 \mathrm{MPa}$ and fluid-saturated conditions but their experiments were run with pure $\mathrm{H}_{2} \mathrm{O}$ and it will be shown below that when $\mathrm{CO}_{2}$ is taken into account, the 3 wt. $\% \mathrm{H}_{2} \mathrm{O}$ estimated for Calbuco probably correspond to volatile saturation. Furthermore, at higher pressure (1.0 $\mathrm{GPa}$ ), anorthite crystallized in a basalt with 2.5 wt. $\% \mathrm{H}_{2} \mathrm{O}$ (Ulmer et al. 2018). Other parameters, such as a high melt $\mathrm{Ca} / \mathrm{Na}$ and/or high melt $\mathrm{Al}_{2} \mathrm{O}_{3}$ content have been proposed as factors also controlling the stability of anorthite in arc magmas (Panjasawatwong et al., 1995). The Calbuco basalts have similar $\mathrm{Ca} / \mathrm{Na}(1.6-1.8)$ than the compositions experimentally studied by Pichavant et al. (2002) (1.9) and Sisson and Grove (1993) (1.8 for basalt 82-66), but their higher $\mathrm{Al}_{2} \mathrm{O}_{3}$ content (average $=21.00$ wt. $\%$ in CL vs. 19.32 wt. $\%$ for Pichavant et al. (2002) and 17.31 for Sisson and Grove (1993)) should favor the anorthite molecule in plagioclase. Consequently, even if the melt $\mathrm{H}_{2} \mathrm{O}$ content partly controls the composition of plagioclase, it is possible that the interplay of several parameters enables the crystallization of anorthite in arc magmas and in the case of Calbuco, anorthite could have been a liquidus phase at moderate $\mathrm{H}_{2} \mathrm{O}$. In agreement with this suggestion, the modelling of Namur et al (2020) indicated that crystallization of the plagioclase An-rich cores requires a basaltic andesite with 3.5-4.5 wt. $\% \mathrm{H}_{2} \mathrm{O}$. In order to have an estimation of the $\mathrm{H}_{2} \mathrm{O}$ content of the melt along the differentiation trend, we used the concentration of the two most incompatible elements, $\mathrm{Zr}$ and $\mathrm{Nb}$, to calculate the fraction of residual melt (f) corresponding to each sample $\left(f=\mathrm{C}_{0} / \mathrm{C}_{\mathrm{L}}\right.$, where $C_{0}$ is the concentration in basalt CL119). Then, using an initial $\mathrm{H}_{2} \mathrm{O}$ content of $3 \mathrm{wt}$. $\%$ in the basalt parent magma and the calculated $f$, the $\mathrm{H}_{2} \mathrm{O}$ content corresponding to each sample was estimated with the Rayleigh distillation law. Regression of these results give the following equation: $\mathrm{H}_{2} \mathrm{O}$ (wt. \%) $=-0.0365$ (wt. $\%$ $\left.\mathrm{SiO}_{2}\right)^{2}+4.6063\left(\right.$ wt. $\% \mathrm{SiO}_{2}$ ) - 136.82. As volatile saturation is not taken into account, this regression only provides a rough estimate which is likely too high at elevated $\mathrm{SiO}_{2}$ content. Given the analytical uncertainties on the trace element content and their propagation into this $\mathrm{H}_{2} \mathrm{O}$ estimation, a minimum error of about $15 \%$ should be considered.

Pressure and temperature can be estimated with the clinopyroxene-liquid equilibrium. Among the 797 analyses 
of clinopyroxene, 255 were found to be in equilibrium with their whole-rock composition $\left(K_{D}^{\mathrm{Fe}-\mathrm{Mg}}=0.27 \pm 0.03\right.$ : Putirka (2008); (DiHd $)_{\text {predicted }}-(\text { DiHd })_{\text {observed }} \leq|0.05|$ : Neave and Putirka (2017)) and indicate an average pressure of $180 \mathrm{MPa}$ with a large standard deviation of $70 \mathrm{MPa}$ using Eq. 32a of Putirka (2008). When testing equilibrium, the melt $\mathrm{Fe}^{3+}$ content was not calculated because the $K_{D}^{\mathrm{Fe}-\mathrm{Mg}}$ was derived from a large experimental database (1245 experiments) using total $\mathrm{Fe}$ in the liquid. Another set of calculations was performed between each clinopyroxene composition and the full whole-rock dataset available for Calbuco, with the hypothesis that any clinopyroxene composition (797 analyses) should have been in equilibrium with a composition lying on the Calbuco trend (180 analyses of whole-rock including data from Sellés and Moreno (2011)) resulting in 143,460 equilibrium tests. We found that 34,787 clinopyroxene-liquid pairs met the criteria of the equilibrium and among these pairs, 22,170 were in equilibrium using the additional DiHd compositional criteria. Temperature and pressure were calculated with Eqs. $33\left(914-1060{ }^{\circ} \mathrm{C}\right.$; mean $=983$ $\left.\pm 26{ }^{\circ} \mathrm{C}\right)$ and $32 \mathrm{a}($ mean $=220 \pm 110 \mathrm{MPa})$ of Putirka (2008) respectively using the melt $\mathrm{H}_{2} \mathrm{O}$ content calculated with the above equation and starting with 3 wt. $\% \mathrm{H}_{2} \mathrm{O}$ in the parent basaltic magma (Supplementary Figs. 5-6). We have taken into account the uncertainty on the $\mathrm{H}_{2} \mathrm{O}$ content of the liquid by adding and subtracting $1 \mathrm{wt}$. \% $\mathrm{H}_{2} \mathrm{O}$ to the calculated value and found similar $\mathrm{P}-\mathrm{T}$ estimates, respectively $904-1047{ }^{\circ} \mathrm{C}\left(\right.$ mean $\left.=972 \pm 25^{\circ} \mathrm{C}\right)$ and $220 \pm 110 \mathrm{MPa}$ as well as $924-1073^{\circ} \mathrm{C}($ mean $=994$ $\pm 26{ }^{\circ} \mathrm{C}$ ) and $220 \pm 110 \mathrm{MPa}$. The clinopyroxene-only and clinopyroxene-liquid geobarometers recently proposed by Petrelli et al. (2020) using a new approach based on machine learning give similar results, respectively 210 $\pm 70 \mathrm{MPa}$ and $330 \pm 30 \mathrm{MPa}$ (Supplementary Fig. 6). These authors showed that the $\mathrm{Na}_{2} \mathrm{O}, \mathrm{Al}_{2} \mathrm{O}_{3}$ and $\mathrm{CaO}$ content of clinopyroxene as well as the $\mathrm{MgO}$ content of the liquid strongly control their model, the $\mathrm{H}_{2} \mathrm{O}$ content of the liquid playing a negligible role. Petrelli et al. (2020) also obtained a clinopyroxene-liquid geothermometer that gives a temperature range of $981-1080{ }^{\circ} \mathrm{C}($ mean $=1009 \pm$ $12{ }^{\circ} \mathrm{C}$ ), slightly higher than those obtained with the above equations. The temperature histograms obtained with the Putirka (2008) (Eq. 33) and Petrelli et al. (2020) models (Supplementary Figs. 5-6) display two peaks, respectively $950{ }^{\circ} \mathrm{C} / 990{ }^{\circ} \mathrm{C}$ and $990{ }^{\circ} \mathrm{C} / 1010^{\circ} \mathrm{C}$, with possibly a third one in the Putirka (2008) distribution. This will be discussed with the results from the Opx-Cpx equilibria. The pressure estimate agrees with previous results on the Calbuco 2015 eruption (Arzilli et al. 2019; Morgado et al. 2019b; Namur et al., 2020) and the temperature range is in agreement with experimental data obtained respectively at $200 \mathrm{MPa}$ and $400 \mathrm{MPa}$ by Parat et al. (2014) and Pichavant et al. (2002) on starting compositions that are similar to the basaltic parent magma (CL119) of Calbuco.

The orthopyroxene-clinopyroxene geothermobarometer was also used to estimate magmatic conditions (Eqs. 36 to 39 of Putirka (2008)). We tested equilibrium between each analysis of clinopyroxene (785 analyses) and each analysis of orthopyroxene (402 analyses). Out of 315,570 tests, equilibrium was found between 3999 pairs. Pressure derived with Eq. $39(\mathrm{P}=390 \pm 100 \mathrm{MPa})$ overlaps within errors with the pressure estimates obtained with the clinopyroxene-melt equilibria whereas Eq. 38 gives a slightly higher pressure $(460 \pm 90 \mathrm{MPa})$ (Supplementary Fig. 5). Some values obtained with Eq. 39, above $1000 \mathrm{MPa}$, correspond to mantle depths and are unrealistically high. The average temperature is $984 \pm 22^{\circ} \mathrm{C}$ and 964 $\pm 29{ }^{\circ} \mathrm{C}$ respectively with Eqs. $36\left(911-1070{ }^{\circ} \mathrm{C}\right)$ and 37 $\left(874-1120{ }^{\circ} \mathrm{C}\right)$. Our results overlap with those of Namur et al. (2020) $\left(T=919-1160{ }^{\circ} \mathrm{C}\right.$, mean $=1013{ }^{\circ} \mathrm{C} ; 1 \sigma=39^{\circ} \mathrm{C}$; $\mathrm{P}($ Eq. 39) mean $=319 \mathrm{MPa}, 1 \sigma=230 \mathrm{MPa}$ ) and Morgado et al. (2019b) $\left(958-1013{ }^{\circ} \mathrm{C}\right.$, mean $=984{ }^{\circ} \mathrm{C}, 1 \sigma=12{ }^{\circ} \mathrm{C}$; $P=150-470 \mathrm{MPa}$, mean $=330 \mathrm{MPa}, 1 \sigma=80 \mathrm{MPa})$ and as already noted by these authors, pressure estimates derived with the two pyroxenes equilibrium are slightly higher than those obtained with the clinopyroxene-melt equilibrium (Fig. 10). The temperature distribution of the orthopyroxeneclinopyroxene equilibria has only one peak $\left(980{ }^{\circ} \mathrm{C}\right.$ with Eq. 36 and $950{ }^{\circ} \mathrm{C}$ with Eq. 37). The experimentally-derived phase diagrams of Parat et al. (2014) and Pichavant et al.

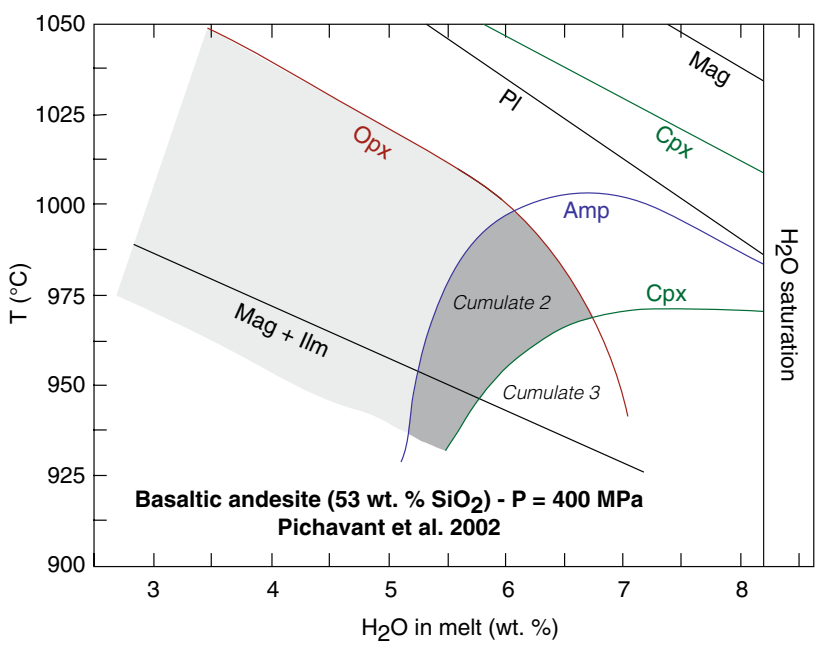

Fig. 12 Phase relations redrawn from Pichavant et al. (2002) for a basaltic andesite of Mount Pelée at $400 \mathrm{MPa}$. The stability curves of mineral phases are labeled with the name inside their stability field. The Opx curve corresponds to saturation at $\Delta \mathrm{NNO}<+1$ (Pichavant et al. 2002). The grey fields show the conditions where both pyroxenes are stable. They are joined by amphibole in the dark grey field. Cumulates 2 and 3 refer to those calculated with the least square regression method (see "Discussion") and are respectively made of $\mathrm{Pl}+\mathrm{Cpx}+\mathrm{Opx}+\mathrm{Amp}+\mathrm{Mag}$ and $\mathrm{Pl}+\mathrm{Opx}+\mathrm{Amp}+\mathrm{Mag}$ 
(2002) both indicate that orthopyroxene appears at a lower temperature than clinopyroxene (Fig. 12). The temperature difference between the two liquidus $\left(\Delta \mathrm{T} \sim 45^{\circ} \mathrm{C}\right)$ is slightly higher than the error of the geothermometers $\left(12{ }^{\circ} \mathrm{C}\right.$ to $26{ }^{\circ} \mathrm{C}$ for the clinopyroxene-melt and $22{ }^{\circ} \mathrm{C}$ to $29^{\circ} \mathrm{C}$ for the orthopyroxene-melt) or within this range, allowing comparison between the experimentally-derived phase diagram and results from geothermobarometry. Both pyroxenes are stable together over a temperature interval that decreases with increasing melt $\mathrm{H}_{2} \mathrm{O}$ content and at more than 7 wt. $\% \mathrm{H}_{2} \mathrm{O}$ in the melt, clinopyroxene destabilizes before the appearance of orthopyroxene (Pichavant et al. 2002) (Fig. 12). The temperature interval obtained with the clinopyroxene-melt equilibria (914-1060 ${ }^{\circ} \mathrm{C}$ with Eq. 33 of Putirka (2008) and 981-1080 ${ }^{\circ} \mathrm{C}$ with the Petrelli et al. (2020) model covers the stability fields of clinopyroxene only and clinopyroxene + orthopyroxene as all possible clinopyroxene-melt equilibria have been tested. It is thus possible that the high temperature peak observed in the clinopyroxene-melt temperature distributions $\left(990^{\circ} \mathrm{C}\right.$ with Eq. 33 of Putirka (2008) and $1010{ }^{\circ} \mathrm{C}$ with the Petrelli et al. (2020) model) corresponds to the crystallization of clinopyroxene only. The low temperature peak could witness the simultaneous crystallization of both pyroxenes: the orthopyroxene-clinopyroxene temperature peak at $950{ }^{\circ} \mathrm{C}$ (Eq. 37) and $980{ }^{\circ} \mathrm{C}$ (Eq. 36) respectively match the low temperature peak of the clinopyroxene-melt thermometer obtained with Eq. $33\left(950{ }^{\circ} \mathrm{C}\right)$ and with the Petrelli et al. (2020) model $\left(990^{\circ} \mathrm{C}\right)$. On the other hand, the simultaneous occurrence of orthopyroxene and clinopyroxene macrocrysts in numerous samples indicate that the $\mathrm{H}_{2} \mathrm{O}$ content of the basaltic andesite was not too high, otherwise with decreasing temperature and increasing $\mathrm{H}_{2} \mathrm{O}$ content with differentiation, the crystallization path would not have crossed the stability field of orthopyroxene (Pichavant et al. 2002) (Fig. 12). Moreover, the maximum temperature $\left(1080{ }^{\circ} \mathrm{C}\right)$ of the clinopyroxene-melt equilibrium points to an $\mathrm{H}_{2} \mathrm{O}$ content of about $3.5 \mathrm{wt}$. \% at the liquidus of this phase. Both observations give further support to the moderate $\mathrm{H}_{2} \mathrm{O}$ content estimated for the basalts.

Igneous amphiboles display a compositional variability that is related to variation in temperature, pressure and melt composition (Erdmann et al. 2014; Putirka 2016; Zhang et al. 2017; Humphreys et al. 2019). As recommended by Putirka (2016), pressure has been estimated with the use of several equations (Eq. 7a and 7c from Putirka (2016) and Eq. 1b and 1c from Ridolfi and Renzulli (2012)). Moreover, our dataset includes a large number of analyses (154) and the other equilibria (Cpx-melt, Opx-Cpx) provide independent estimates. As the use of the barometers requires pairs of amphibole and melt that are in equilibrium, we have used the AEMs calculated with the Humphreys et al. (2019) regressions. This method is also justified by the observation that many amphiboles at Calbuco are in equilibrium with melt composition plotting in the Daly gap or with melt of dacitic compositions that are not present in our whole-rock dataset. As $\mathrm{MnO}, \mathrm{Na}_{2} \mathrm{O}$ and $\mathrm{P}_{2} \mathrm{O}_{5}$ are not provided in the AEMs and $\mathrm{K}_{2} \mathrm{O}$ is not well predicted in the AEMs probably because of the low $\mathrm{K}_{2} \mathrm{O}$ in the Calbuco amphibole (0.09-0.37 wt.\%, average $=0.19 \mathrm{wt} . \%)$, these values have been calculated using regression lines fitted on the WR trend (e.g., $\mathrm{K}_{2} \mathrm{O}$ (wt.\%) $=0.0515 * \mathrm{SiO}_{2}$ (wt.\%) -2.2504). The partition coefficient of $\mathrm{Fe} / \mathrm{Mg}$ was calculated between each amphibole analysis and each AEMs (54.89-76.8 wt. \% $\left.\mathrm{SiO}_{2}\right)$. It is decreasing with increasing melt wt. $\% \mathrm{SiO}_{2}$ in agreement with experimental data (Sisson and Grove 1993; Grove et al. 1997; Martel et al. 1999; Pichavant et al. 2002; Parat et al. 2014) (Supplementary Fig. 7). A regression through the data gives $K_{D}^{\mathrm{Fe}-\mathrm{Mg}}=-0.0168 \% \mathrm{SiO}_{2}+1.343\left(R^{2}=0.93\right)$ when excluding the outliers that plot significantly higher than the trend at about 55 and 61 wt. \% $\mathrm{SiO}_{2}$ (Supplementary Fig. $7 \mathrm{~b}$ ). The $K_{D}^{\mathrm{Fe}-\mathrm{Mg}}=0.28 \pm 0.11$ proposed by Putirka (2016) overlaps most of this trend when the errors are taken into account (0.17-0.39) (Supplementary Fig. 7b). Results obtained when excluding amphibole/AEM pairs that have $\mathrm{Kds}$ above the main $\mathrm{Kd}-\% \mathrm{SiO}_{2}$ trend or when considering the whole dataset give similar results, respectively 282 $\pm 163 \mathrm{MPa}$ (Eq. 7a using an $\mathrm{H}_{2} \mathrm{O}$ content of $6 \mathrm{wt} . \%$ ), 343 $\pm 175 \mathrm{MPa}$ (Eq. $7 \mathrm{a}$ with an $\mathrm{H}_{2} \mathrm{O}$ content calculated with the above equation), 249 $\pm 148 \mathrm{MPa}$ (Eq. 7c which is independent of the $\mathrm{H}_{2} \mathrm{O}$ content) and in the same order $273 \pm$ $158 \mathrm{MPa}, 335 \pm 169 \mathrm{MPa}, 236 \pm 148 \mathrm{MPa}$ (Supplementary Fig. 8a). Limiting the dataset to pairs giving $\mathrm{Kds}$ in the range proposed by Putirka (2016) indicate slightly higher pressures but still overlapping with the previous values when errors are considered (in the same order): $330 \pm 130 \mathrm{MPa}, 410$ $\pm 130 \mathrm{MPa}$, or $270 \pm 140 \mathrm{MPa}$ (Supplementary Fig. 8b). Equations 1b and 1c of Ridolfi and Renzulli (2012), calibrated for a pressure range of 130-500 MPa and based on the composition of amphibole alone, give pressure respectively of $420 \pm 110 \mathrm{MPa}$ and $420 \pm 97 \mathrm{MPa}$ while the Ridolfi et al. (2010) empirical regression gives a pressure of 300 $\pm 70 \mathrm{MPa}$. Temperatures estimated with the equations proposed by Putirka (2016) (Eq. 5 that is pressure independent) range from $847{ }^{\circ} \mathrm{C}$ to $1003{ }^{\circ} \mathrm{C}$ (average at $950 \pm 29{ }^{\circ} \mathrm{C}$ ) whereas the Ridolfi et al. (2010) thermometer gives temperatures from 802 to $1026{ }^{\circ} \mathrm{C}$ (average at $940 \pm 49{ }^{\circ} \mathrm{C}$ ) (Supplementary Fig. 8b). Finally, the oxygen fugacity and water content of the melt in equilibrium with the amphiboles is respectively $\mathrm{NNO}+0.9( \pm 0.2)$ (range from $\mathrm{NNO}+0.6$ to $\mathrm{NNO}+1.4$ ) and an average of $7.0 \mathrm{wt}$ \% (range from 5.0 to 8.9 wt. \%) (Ridolfi et al. 2010). These temperature and $\mathrm{H}_{2} \mathrm{O}$ content values agree with the phase relations of Pichavant et al. (2002) for the simultaneous stability of amphibole and both pyroxenes as observed in glomerocrysts (Fig. 12).

The pressure estimates are summarized on Fig. 10 and range from to 210 to $460 \mathrm{MPa}$. They are similar to those 
obtained for the 2015 eruption suggesting that the location of the upper crustal magma reservoir beneath Calbuco is steady with time. They are moreover in the range of magma storage depth in different tectonic settings including volcanic arcs and interpreted as controlled both by volatile saturation and crustal rheology (Huber et al. 2019). We note that, in the SVZ, these pressures correspond to the location of an intracrustral discontinuity (Fig. 10) (Tassara et al. 2006; Tassara and Echaurren 2012) and possibly to the depth of volatile saturation. As discussed above the pre-eruptive $\mathrm{H}_{2} \mathrm{O}$ content of the Calbuco basalts has been estimated to 3-3.5 wt\%, an estimation supported by melt inclusions data, the modelling of Namur et al. (2020) and experimentally-derived phase relations (occurrence of Opx together with $\mathrm{Cpx}$, maximum temperature of Cpx-melt equilibrium). Due to the low solubility of $\mathrm{CO}_{2}$ in silicate melts (Dixon 1997), volatile saturation strongly depends on the $\mathrm{CO}_{2}$ content. There are currently no data on the $\mathrm{CO}_{2}$ content at Calbuco (Bechon et al., in prep) and data for the whole SVZ are scarce and range from 0-300 ppm (Llaima: Bouvet de Maisonneuve et al. (2012)) to 0-1238 ppm (Apagado, Hornopiren, Palena, South Minchinmavida: Watt et al. (2013)). These values are within the range deduced for arc magmas based on melt inclusion studies (25 up to 3000 ppm: e.g. Wallace (2005); Blundy et al. (2010)). If we consider 3 wt. $\% \mathrm{H}_{2} \mathrm{O}$ and $1200 \mathrm{ppm}$ or $600 \mathrm{ppm} \mathrm{CO}_{2}$, the model of Ghiorso and Gualda (2015) indeed indicates volatile saturation respectively at $360 \mathrm{MPa}$ (molar $X_{\mathrm{H} 2 \mathrm{O}}$ in the fluid of 0.38 ) and $235 \mathrm{MPa}$ (molar $X_{\mathrm{H} 2 \mathrm{O}}$ in the fluid of 0.51 ). These estimates thus suggest volatile saturation in the pressure range of the main storage region as also deduced for the La Picada volcano (Vander Auwera et al. 2019).

\section{Discussion}

\section{The Calbuco trend approximates a liquid line of descent}

Individual lava flows usually display a narrow compositional range as observed at Calbuco (Unit 3) (57.10-57.50 wt. \% $\mathrm{SiO}_{2}$ ) (in preparation) and at other volcanoes (e.g. Neave et al. 2014; Ruth et al. 2016). Consequently, the whole differentiation trend of Calbuco, corresponding to the sum of its different eruptive events, witnesses the evolution of the magma storage region since $342 \mathrm{ky}$. Sampling the different units of a volcano is akin to sampling bulk plutons, which likely correspond to the uneruptable roots of now eroded volcanoes and which grew incrementally by episodic magma injection (e.g. Glazner et al. 2004). As macrocrysts occurring in a specific lava sample are not all in equilibrium with the whole-rock (e.g. Cashman and Blundy 2013; Neave et al. 2014), each sample on the trend cannot be representative of a true liquid composition, a hypothesis that would also imply perfect separation between liquid and crystals in the magma storage region. However, the WR trend observed here, and in other volcanoes (e.g. Eichelberger et al. 2006; Vander Auwera et al. 2019), is not chaotic and follows experimental liquid lines of descent acquired at shallow pressure and appropriate oxygen fugacity on starting compositions that are close to the Calbuco basalts (Fig. 13). Moreover, the pyroclasts (53-62 wt. \% $\mathrm{SiO}_{2}$ ) and lava (51-65 wt. \% $\mathrm{SiO}_{2}$ ) trends overlap even if their eruption was respectively explosive and effusive. This raises the question of why these bulk rock compositions (lavas, pyroclasts) follow liquid line of descent given their textural complexities and the explosivity of some events. One way to reconcile these observations is that macrocrysts are transported in the melt in near cotectic proportions. The relative proportions of plagioclase and pyroxenes measured in the 2015 pyroclasts (mostly basaltic andesites) (70\% Pl+25 to 30 wt. \% Px: Namur et al. (2020); or $79 \% \mathrm{Pl}+19 \% \mathrm{Px}$ : Arzilli et al. (2019)) are similar to those measured in the basaltic andesites lavas $(70 \% \mathrm{Pl}+30 \% \mathrm{Px})$ and indeed compare rather well with the composition of our calculated cumulate for the basaltic andesites (67\% plagioclase $+33 \%$ pyroxenes with amphibole counted as pyroxenes since amphibole reacted out in lavas and most pyroclasts; see "Discussion") providing some support to this hypothesis. Experimental data can be used to further test this suggestion. Indeed, cotectic proportions can be estimated by mass balance calculations using two experimental runs having the same cumulus assemblage (thus lying on the same cotectic) but different degrees of crystallization (higher and lower temperature) (e.g. Charlier et al. 2018). However, they will represent instantaneous cotectic proportions corresponding to an increment of crystallization and if it appears that the cotectic is significantly curved, these proportions should vary with progressive crystallization. Comparison between experiments and natural samples is thus not fully adequate but nevertheless interesting to test. We identified experimental runs where the composition of the glass was close to sample CL67, selected as the residual liquid of our model (see "Discussion") (runs AB73 and 74 of Almeev et al. (2013); \#8 of Parat et al. (2014); 2390 of Blatter et al. (2013); 1618 of Kawamoto (1996) and HAB14 of Pichavant et al. (2002)). Among these, only the dataset of Kawamoto (1996) provides two successive runs with the same mineral assemblages (runs 1618 and 1616) and the estimated cotectic proportions are $58 \% \mathrm{Pl}+42 \mathrm{Px}$. These values are not too different from the measured proportions given that the pressure $(500 \mathrm{MPa})$ and melt $\mathrm{H}_{2} \mathrm{O}$ content $(2.7 \mathrm{wt}$. \% in run 1618) of these experiments are respectively higher and lower than those of Calbuco and these two parameters strongly influence the stability field of plagioclase. In the following, we will thus consider that the observed WR trend approximates a liquid line of descent and, as it integrates the whole 

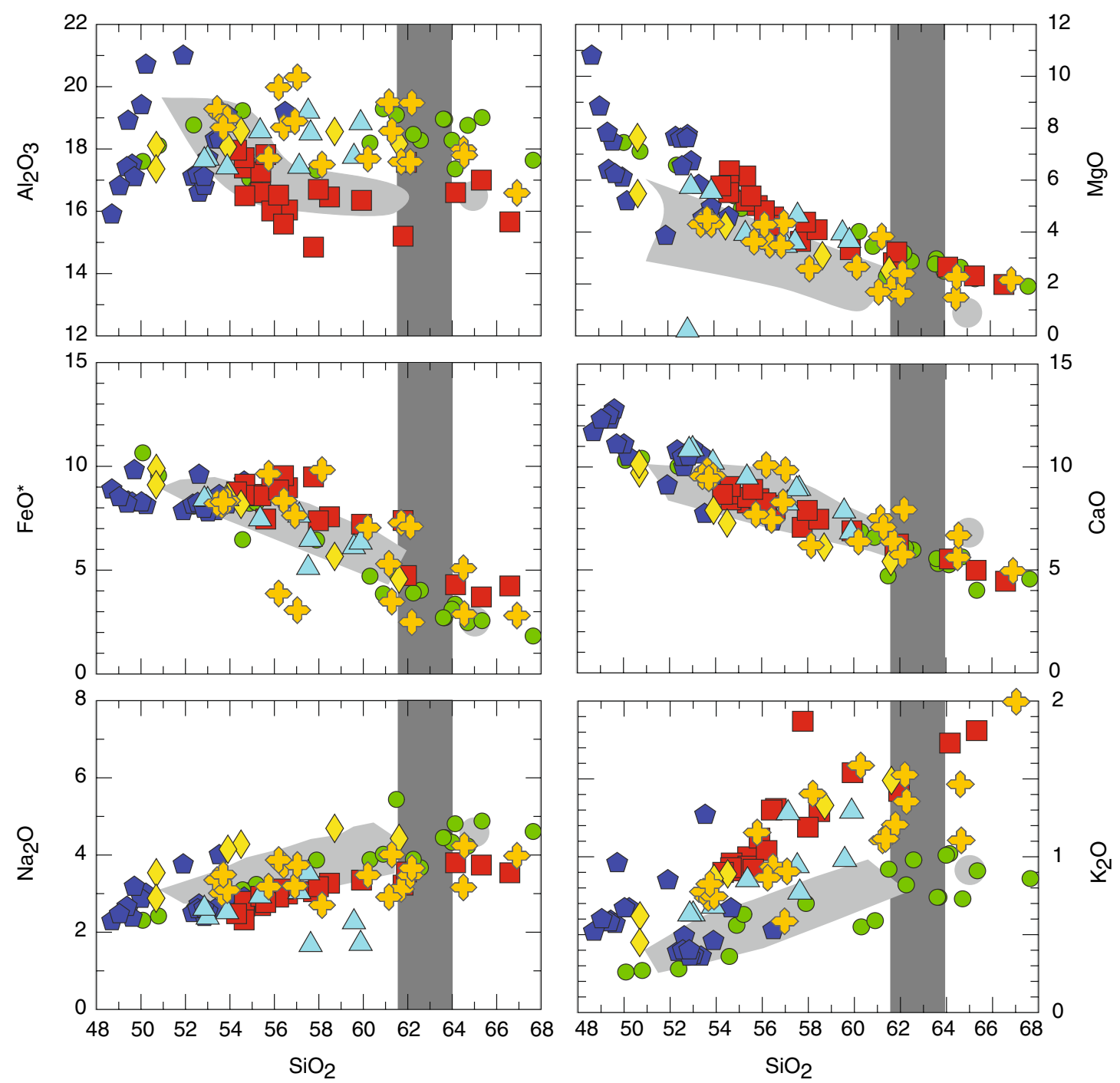

\begin{tabular}{|lll|}
\hline CL trend vs. experimental data & & \\
Kawamoto & $\square$ & Almeev $1 \mathrm{~kb}$ \\
Pichavant \& Mac Donald & $\triangle$ & Parat \\
$\nabla$ Blatter & Calbuco WR \& pyroclasts trend \\
$\&$ Pichavant et al & Calbuco Daly gap \\
\hline
\end{tabular}

Fig. 13 Major element Harker diagrams (wt. \%) comparing the Calbuco samples (grey field) with experimental data (Kawamoto 1996; Pichavant et al. 2002; Pichavant and Macdonald 2007; Almeev et al.

lifespan of the volcano, it is interpreted as made of different magma batches that have undergone similar magmatic processes and adjacent samples along the trend do not have a direct parent/residual relation (Eichelberger et al. 2006). The overlapping AEMs and observed geochemical trends support this approximation (Fig. 9).
2013; Blatter et al. 2013; Parat et al. 2014). The position of the Daly gap is shown as the dark grey field. Analyses recalculated to $100 \mathrm{wt}$. $\%$ on a volatile free basis with total $\mathrm{Fe}$ as $\mathrm{FeO}_{\mathrm{t}}$

\section{Modelling of the differentiation trend}

It was demonstrated that the restricted chemical diversity (53-56 wt. $\% \mathrm{SiO}_{2}$ ) of the 2015 pyroclasts can be predicted by the variable accumulation (23-56 wt.\%) of minerals with constant composition $(72 \% \mathrm{Pl}+14 \% \mathrm{Opx}+14 \% \mathrm{Cpx})$ in a dacitic melt (Namur et al. 2020). Contrarily, in the lavas, the mineralogy changes with increasing $\mathrm{SiO}_{2}$ (see "Petrography" 
section) and the highest $\mathrm{Mg \# s}$ were measured in the cores of the mafic minerals present in the basalts and basaltic andesites. This suggests that the crystal mush is zoned and is not randomly unlocked by the ascending magma, maybe as melt-rich pockets that are still or not far from equilibrium with the surrounding cumulates, thus indicating another differentiation process. Magma replenishment accompanied by variably efficient mixing, wall-rock assimilation and fractional crystallization have long been recognized as major magmatic processes (e.g. Frost and Frost 2019). The extensive mineral composition database from Namur et al. (2020) and this study indicate that the ferromagnesians (Cpx, Opx, Ol, Amp) are mostly unzoned or normally zoned, reverse zoning being rare. Also, plagioclase macrocrysts frequently display An-rich cores ( $\mathrm{An}_{80-94}$ in the different rock types) surrounded by a more albitic rim (Fig. 3a). Namur et al. (2020) interpreted these plagioclase textures as resulting from the accumulation of the An-rich cores in the crystal mush and their later unlocking and entrainment in the carrying melt inducing crystallization of the rim. The lack of rim at the contact of plagioclase grains occurring in the glomerocrysts clearly supports this conclusion (Fig. 3b-d). The lower An content of the rim can result from a lower $\mathrm{Ca} / \mathrm{Na}$ in the melt and/or lower $\mathrm{H}_{2} \mathrm{O}$ melt content due to devolatilization during ascent or/and decompression. Consequently, the fact that crystals are mostly unzoned or with normal zoning precludes magma mixing being a dominant process, a conclusion also supported by the lack of mingling relationships on the outcrops. However, this does not exclude episodic recharge at the base of the mush, as suggested by Castruccio et al. (2016), Morgado et al. (2019a), Morgado et al. (2019b) and Namur et al. (2020). Sr and Nd isotopic composition of the Calbuco lavas suggest some assimilation of the country rocks as discussed by Lopez-Escobar et al. (1995). Fractional crystallization is supported as a dominant process by a straight line passing through the origin in incompatible element plots (Supplementary Fig. 9). It is not interpreted as resulting from crystal settling in a large body of magma as our understanding of shallow magmatic systems has evolved from a melt-dominated magma chamber to a high crystallinity crystal mush where crystals are kept mostly at near solidus temperatures (Cooper and Kent 2014; Rubin et al. 2017). Several physical processes can contribute to fractional crystallization (e.g. Namur et al. 2015). Compaction (e.g. Tegner et al. 2009) and/or compositional convection (e.g. Namur and Charlier 2012) inducing percolative transfer of buoyant melt in the crystal mush (Solano et al. 2014; Cashman et al. 2017; Jackson et al. 2018) have been identified as major processes. End members equations that are generally used to model fractional or equilibrium crystallization cannot predict the full details of the geochemical variations that are possibly produced by such percolative melt transfer (Jackson et al., 2018). However, they enable us to model the bulk process of differentiation by taking into account the changing phase equilibria with differentiation.

The fractional crystallization process has been modelled in three steps using the least square regression method (Stormer and Nicholls 1978) and samples CL119 (51.25 wt. \% $\mathrm{SiO}_{2}$ ), CL04 (53.87 wt. \% $\mathrm{SiO}_{2}$ ), CL67 (57.50 wt. \% $\mathrm{SiO}_{2}$ ) and CL40 (61.23 wt. \% $\mathrm{SiO}_{2}$ ). Indeed, the RhyoliteMELTS thermodynamic model cannot be used to reproduce the whole trend as amphibole is a crystallizing phase (Gualda et al. 2012; Ghiorso and Gualda 2015). However, according to this model plagioclase and magnetite are early liquidus phases of basalt CL119 followed by olivine and then clinopyroxene (200 MPa, NNO to NNO + 1 and 3-3.5 wt. $\% \mathrm{H}_{2} \mathrm{O}$ ), in agreement with petrographic data and with the decrease of $\mathrm{V}$ (Ti-Mgt) and $\mathrm{Sc}(\mathrm{Cpx})$ with increasing $\mathrm{SiO}_{2}$ (Fig. 8). Results of the mass balance (proportions of the subtracted minerals in the cumulate, fraction of residual liquid and calculated residual liquid) are shown in Table 4 and were further tested with a selection of trace elements using the Rayleigh distillation law (proportions of the subtracted minerals in the cumulate, fraction of residual liquid taken from the results of the major elements mass balance) and appropriate partition coefficients (Table 5). In each step, the composition of the subtracted phases has been estimated in the following way. We first calculated the Mg\# (olivine $K_{D}^{\mathrm{Fe}-\mathrm{Mg}}=0.3$ (Roeder and Emslie 1970); clinopyroxene $K_{D}^{\mathrm{Fe}-\mathrm{Mg}}=0.27$ (Putirka 2008); orthopyroxene $K_{D}^{\mathrm{Fe}-\mathrm{Mg}}=$ 0.29 (Putirka 2008)) of the phases that are in equilibrium with the starting (L0) and final (L1) compositions of each step. Then, as the least square regression method estimates a bulk cumulate for a much larger step of differentiation than Rhyolite-MELTS (Gualda et al. 2012; Ghiorso and Gualda 2015), the phases composition of the subtracted cumulate was taken in the middle of the range defined by the minerals in equilibrium with L0 and L1. Plagioclase composition was estimated by trial and errors as its composition depends on several parameters (e.g. Sisson and Grove 1993; Panjasawatwong et al. 1995). The Ti-Mgt composition (Usp32 from $\mathrm{CL}<$ Subscript $>3</$ Subscript $>2$, analysis Ti-Mgt4) was chosen using the model of Ghiorso and Sack (1991) for a temperature range of $1150-1060{ }^{\circ} \mathrm{C}$ (Eq. 13 using the $\mathrm{MgO}$ content of the whole-rock (Putirka 2008) and an $f_{\mathrm{O} 2}$ of FMQ +2 in agreement with the amphibole composition). Mineral compositions were then selected in our extensive microprobe database, they thus implicitly have compositions that are appropriate for the $\mathrm{P}, \mathrm{T}, \mathrm{H}_{2} \mathrm{O}$ content of Calbuco. In step 1 , a gabbroic cumulate is subtracted $(61 \% \mathrm{Pl}+25 \%$ $\mathrm{Ol}+9 \% \mathrm{Cpx}+5 \% \mathrm{Ti}-\mathrm{Mag}$ ) and the fraction of residual liquid is 0.76 . The test with the trace elements supports this cumulate (Table 6). There is a good agreement between the calculated trace element content of the residual liquid and the observed value in CL04 or in the samples having a composition close to CL04. However, the calculated Sc 
Table 4 Model differentiation of the Calbuco trend from the parent basalt to the most evolved andesite

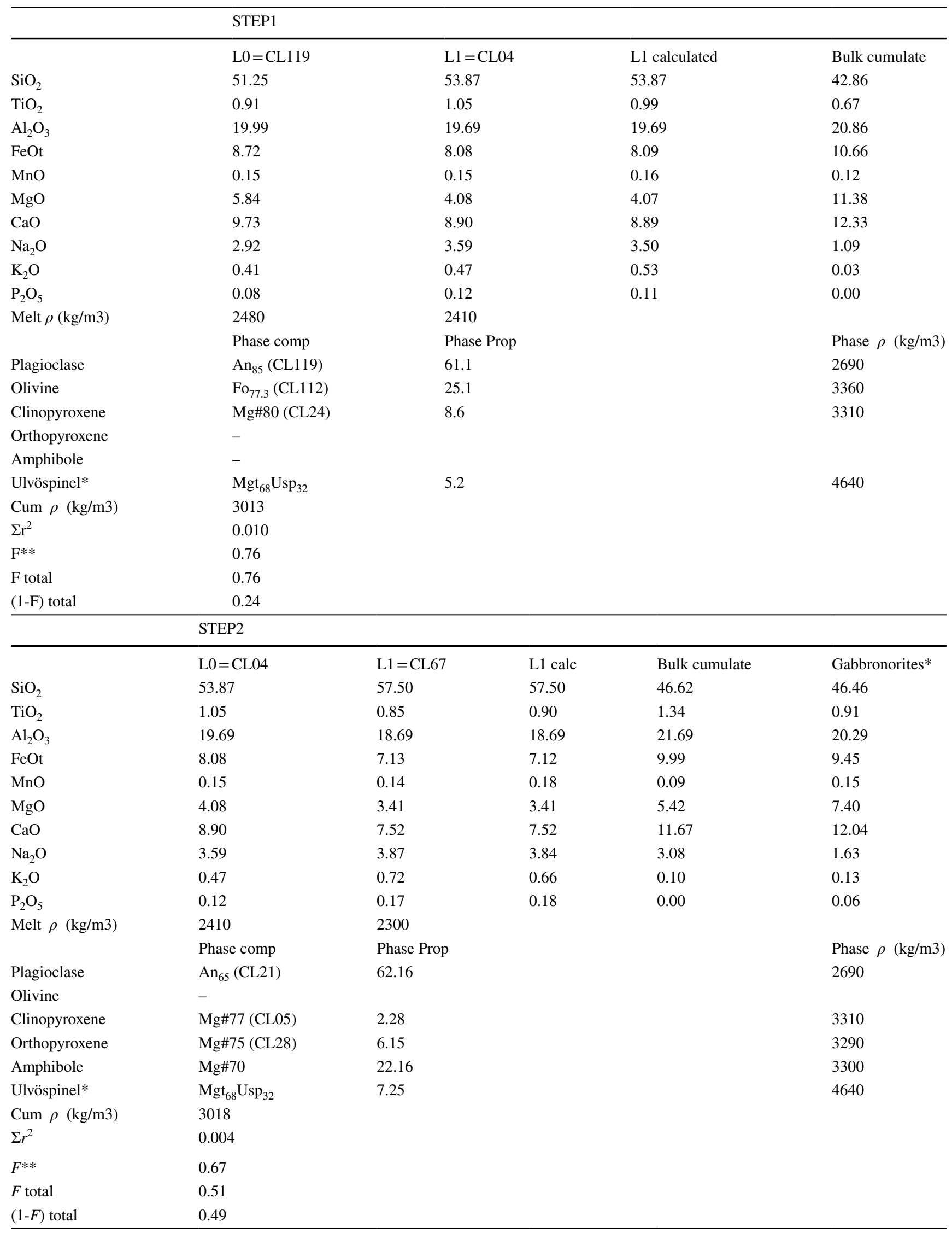


Table 4 (continued)

\begin{tabular}{|c|c|c|c|c|}
\hline & \multicolumn{4}{|l|}{ STEP3 } \\
\hline & $\mathrm{L} 0=\mathrm{CL67}$ & $\mathrm{L} 1=\mathrm{CL} 40$ & L1 calculated & Bulk cumulate \\
\hline $\mathrm{SiO}_{2}$ & 57.50 & 61.23 & 61.23 & 47.66 \\
\hline $\mathrm{TiO}_{2}$ & 0.85 & 0.60 & 0.67 & 1.34 \\
\hline $\mathrm{Al}_{2} \mathrm{O}_{3}$ & 18.69 & 18.20 & 18.21 & 20.05 \\
\hline $\mathrm{FeOt}$ & 7.13 & 5.65 & 5.64 & 11.18 \\
\hline $\mathrm{MnO}$ & 0.14 & 0.13 & 0.13 & 0.16 \\
\hline $\mathrm{MgO}$ & 3.41 & 2.42 & 2.42 & 6.09 \\
\hline $\mathrm{CaO}$ & 7.52 & 6.42 & 6.41 & 10.55 \\
\hline $\mathrm{Na}_{2} \mathrm{O}$ & 3.87 & 4.33 & 4.23 & 2.91 \\
\hline $\mathrm{K}_{2} \mathrm{O}$ & 0.72 & 0.85 & 0.95 & 0.09 \\
\hline $\mathrm{P}_{2} \mathrm{O}_{5}$ & 0.17 & 0.17 & 0.23 & 0.00 \\
\hline \multirow[t]{2}{*}{ Melt $\rho(\mathrm{kg} / \mathrm{m} 3)$} & 2300 & 2250 & & \\
\hline & Phase comp & Phase Prop & & Phase $\rho(\mathrm{kg} / \mathrm{m} 3)$ \\
\hline Plagioclase & $\mathrm{An}_{65}\left(\mathrm{CL}_{2} 1\right)$ & 60.9 & & 2650 \\
\hline Olivine & - & & & \\
\hline Clinopyroxene & - & - & & \\
\hline Orthopyroxene & Mg\#72 (CL05) & 14.2 & & 3290 \\
\hline Amphibole & $\mathrm{Mg \# 60}$ & 18.0 & & 3300 \\
\hline Ulvöspinel* & $\mathrm{Mgt}_{68} \mathrm{Usp}_{32}$ & 6.86 & & 4640 \\
\hline $\operatorname{Cum} \rho(\mathrm{kg} / \mathrm{m} 3)$ & 2993 & & & \\
\hline$\sum r^{2}$ & 0.016 & & & \\
\hline$F^{* *}$ & 0.73 & & & \\
\hline$F$ total & 0.37 & & & \\
\hline$(1-F)$ total & 0.63 & & & \\
\hline
\end{tabular}

*Average composition of the gabbronoritic enclaves (Hickey-Vargas et al., 1995)

$\Sigma r^{2}=$ sum of the squares of residuals

$F^{* *}=$ fraction of residual liquid at each step

$F$ total $=$ total fraction of residual liquid

Densities were calculated with Rhyolite-Mets at $200 \mathrm{MPa}$ and FMQ + 1

content in L1 (37 ppm) is slightly higher than the observed values (30 ppm in CL04 and 10 to $35 \mathrm{ppm}$ in the range of L1). In step 2, subtraction of an amphibole-bearing gabbronoritic cumulate $(62 \% \mathrm{Pl}+22 \% \mathrm{Amp}+3 \% \mathrm{Cpx}+6 \%$ $\mathrm{Opx}+7 \%$ Ti-Mag) drives the liquid from a basaltic andesite to an andesite with a fraction of residual liquid of 0.67 , the total fractionation at this stage being $49 \%$ (Table 4). The presence of amphibole in the cumulate is justified by petrographic observations and by the composition of calculated melts in equilibrium with amphibole (55.05-76.8 wt. $\% \mathrm{SiO}_{2}$ ) (Humphreys et al. 2019). The composition of the hornblende-rich gabbronoritic enclaves (Pl: 45-52\%, Amp: 1-28\%, Cpx: 6-17\%, Opx: 8-21\%, Ti-Mag: 5-12\%), interpreted as cognate by Hickey-Vargas et al. (1995), closely match the bulk and mineralogical composition of the calculated cumulate (Table 4 ) and their pyroxenes (Cpx: Mg\# 0.74-0.75; Opx: Mg\# 0.72-0.75 (Hickey-Vargas et al. 1995)) are similar to our selected compositions (respectively $\mathrm{Mg \#}$
0.77 and $\mathrm{Mg \#} \mathrm{0.75).} \mathrm{Here} \mathrm{too} \mathrm{the} \mathrm{test} \mathrm{with} \mathrm{trace} \mathrm{elements}$ corroborates results from the major element model. The calculated $\mathrm{Rb}$ content of the residual liquid (13 ppm in $\mathrm{L}_{2}$ : Table 6) is within the range (9-23 ppm) but lower than in CL67 (18 ppm) probably because the Rb content of CL04 is low (9 ppm) compared to the other samples (>10 ppm). Increasing the $\mathrm{Rb}$ content to $12 \mathrm{ppm}$ in the starting composition results in a calculated residual liquid with $18 \mathrm{ppm}$ of $\mathrm{Rb}$. $\mathrm{Sr}$ is rather constant with differentiation in agreement with the data of Namur et al. (2020) who measured similar Sr content in the core $(637 \pm 7 \mathrm{ppm})$ and rim $(664 \pm 7 \mathrm{ppm})$ of plagioclase. Using the Sr composition of the core and about $350 \mathrm{ppm}$ in the melt, the calculated partition coefficient of $\mathrm{Sr}$ in plagioclase is 1.8 close to our selected value of 1.7 (Table 5). Moreover, the calculated bulk partition coefficient is 1.2 (Table 6) in agreement with the observed constant Sr. The MREE and HREE calculated content is higher than the observed range. Apatite saturation temperatures range 
Table 5 Partition coefficients for trace elements

\begin{tabular}{lllllll}
\hline & Plag & Olivine & Opx & Cpx & Ti-Mag & Amphibole \\
\hline $\mathrm{Sc}$ & $0.04^{(1)}$ & $0.18^{(8)}$ & $1.29^{(7)}$ & $4^{(12)}$ & $1.7^{(18)}$ & $7.702^{(21)}$ \\
$\mathrm{V}$ & $0.03^{(2)}$ & $0.034^{(7)}$ & $0.5^{(7)}$ & $1.4^{(13)}$ & $15.8^{(13)}$ & $6^{(21)}$ \\
$\mathrm{Co}$ & $0.09^{(3)}$ & $5.2^{(7)}$ & $2.48^{(7)}$ & $0.95^{(7)}$ & $7.4^{(19)}$ & $2^{(11)}$ \\
$\mathrm{Zn}$ & $0.17^{(4)}$ & $1.8^{(9)}$ & $2.6^{(10)}$ & $0.25^{(14)}$ & $15.5^{(18)}$ & $1.6^{(11)}$ \\
$\mathrm{Rb}$ & $0.01^{(3)}$ & $0.01^{(9)}$ & $0.01^{(11)}$ & $0.01^{(15)}$ & $0.01^{(4)}$ & $0.33^{(22)}$ \\
$\mathrm{Sr}$ & $1.7^{(5)}$ & $0.0005^{(7)}$ & $0.0021^{(7)}$ & $0.16^{(16)}$ & $0.01^{(4)}$ & $0.48^{(22)}$ \\
$\mathrm{Ba}$ & $0.3^{(3)}$ & $0.004^{(9)}$ & $0.01^{(10)}$ & $0.0058^{(16)}$ & $0.1^{(4)}$ & $0.3^{(11)}$ \\
$\mathrm{Ce}$ & $0.048 / 0.045^{(6)}$ & $0.0001^{(9)}$ & $0.01^{(10)}$ & $0.22 / 0.19^{(17)}$ & $0.02^{(20)}$ & $0.68^{(22)}$ \\
$\mathrm{Eu}$ & $0.226^{(7)}$ & $0.004^{(9)}$ & $0.06^{(10)}$ & $0.72^{(17)}$ & $0.02^{(20)}$ & $2.5^{(22)}$ \\
$\mathrm{Sm}$ & $0.024^{(6)}$ & $0.003^{(9)}$ & $0.05^{(10)}$ & $0.64^{(17)}$ & $0.02^{(20)}$ & $2^{(22)}$ \\
$\mathrm{Yb}$ & $0.003 / 0.002^{(6)}$ & $0.049^{(9)}$ & $0.23^{(10)}$ & $0.70 / 0.76^{(17)}$ & $0.02^{(20)}$ & $2.19^{(21)}$ \\
\hline
\end{tabular}

(1) Aigner-Torres et al (2007)

(2) Dunn and Sen (1994)

(3) Bédard (2006)

(4) Ewart and Griffin (1994)

(5) Blundy and Wood (1991)

(6) Blundy and Wood (2003) (Lattice Strain Model with $\mathrm{D}_{0}$ from Aignes-Torres et al. (2007)

(7) Laubier et al (2014)

(8) Beattie (1994)

(9) Bédard (2005) use of $\mathrm{D}_{0}, \mathrm{E}^{3+}$ and $\mathrm{r}_{0}$ in the Lattice Strain Model except for $\mathrm{Zn}, \mathrm{Rb}, \mathrm{Ba}$ for which the regressions were used

(10)Bédard (2007) LSM for the REE, regressions for the other elements

(11) Bacon and Druitt (1988)

(12) Gallahan \& Nielsen (1992)

(13) Toplis and Corgne (2002)

(14) Adam and Green (2006)

(15) Bédard (2014)

(16) Hauri et al. (1994)

(17) Wood and Blundy (1997) LSModel

(18) Sievwright et al (2017)

(19) Dostal et al (1983)

(20) Lemarchand et al (1987)

(21) Nandedkar et al (2014)

(22) Humphreys et al (2019)

$X / X=$ values for Step1/values for steps 2 and 3 from 643 to $864{ }^{\circ} \mathrm{C}$ (Harrison and Watson 1984) indicating that it was not a liquidus phase. Amphibole is thus the only phase that fractionates the REE and it is possible that the partition coefficients from Humphreys et al. (2019) are underestimated. Indeed, our bulk partition coefficients are generally similar to those estimated by Hickey-Vargas et al. (1995) between gabbronoritic enclaves and enclosing andesitic magma, except for $D_{\mathrm{Sm}}$ and $D_{\mathrm{Yb}}$ that are significantly higher in their dataset (Table 6). The latter are close to 1 , which agrees with the variations diagrams where the MREE (Sm) and HREE (Yb) display a slight increase from 51 to $54 \mathrm{wt}$. \% $\mathrm{SiO}_{2}$ followed by a flat trend (Fig. 8). Moreover, the slope change at 54 wt. $\% \mathrm{SiO}_{2}$ corresponds both to the appearance of amphibole in the samples (54.89-61 wt. $\left.\% \mathrm{SiO}_{2}\right)$ and to the less differentiated AEMs (55.05-76.8 wt. $\% \mathrm{SiO}_{2}$ ). In step 3, subtraction of a dioritic cumulate $(61 \% \mathrm{Pl}+18 \% \mathrm{Amp}+14 \% \mathrm{Opx}+7 \% \mathrm{Ti}-\mathrm{Mag})$ drives the liquid to the most evolved andesite, just before the Daly gap. Clinopyroxene is absent in this cumulate because no acceptable solution was obtained when adding this phase (negative proportion of clinopyroxene or inappropriate mineral compositions). This result probably reflects the reaction relation clinopyroxene + liquid $=$ amphibole that has been observed experimentally (e.g. Holloway and Burnham 1972). Moreover, the second and third cumulates are in agreement with the experimental phase relations of Pichavant et al. (2002) (see Fig. 12). 
Table 6 Test of the major element model with trace elements

\begin{tabular}{|c|c|c|c|c|c|c|c|c|c|c|}
\hline \multicolumn{11}{|c|}{ Step1 } \\
\hline & $\mathrm{L} 0=\mathrm{CL} 119$ & \multicolumn{2}{|l|}{$\mathrm{L} 1=\mathrm{CLO} 4$} & \multicolumn{2}{|c|}{ L1 calc } & L1 Min & L1 Max & L1 Average & \multicolumn{2}{|l|}{ L1 Median } \\
\hline $\mathrm{Sc}^{*}$ & 32 & \multicolumn{2}{|l|}{30.1} & \multicolumn{2}{|l|}{37} & 10 & 35 & 26 & \multicolumn{2}{|l|}{30} \\
\hline $\mathrm{V}^{*}$ & 249 & \multicolumn{2}{|l|}{239} & \multicolumn{2}{|l|}{251} & 80 & 273 & 212 & \multicolumn{2}{|l|}{227} \\
\hline Co & 30 & \multicolumn{2}{|l|}{24} & \multicolumn{2}{|l|}{24} & 12 & 28 & 22 & 24 & 1.83 \\
\hline $\mathrm{Zn} *$ & 78 & \multicolumn{2}{|l|}{84} & \multicolumn{2}{|l|}{70} & 62 & 89 & 77 & 78 & 1.38 \\
\hline $\mathrm{Rb}$ & 9.3 & 9.0 & & 12 & & 9 & 17 & 14 & 14 & 0.01 \\
\hline $\mathrm{Sr}^{*}$ & 391 & 348 & & 439 & & 252 & 472 & 345 & 343 & 1.05 \\
\hline $\mathrm{Ba}$ & 115 & 125 & & 143 & & 94 & 174 & 129 & 135 & 0.19 \\
\hline $\mathrm{Ce}$ & 9.2 & 14.6 & & 12 & & 13 & 16 & 15 & 16 & 0.05 \\
\hline $\mathrm{Eu}$ & 0.79 & 1.10 & & 1.0 & & 0.9 & 1.1 & 1.0 & 1.0 & 0.20 \\
\hline $\mathrm{Sm}$ & 2.0 & 3.1 & & 2.6 & & 2.7 & 3.2 & 3.0 & 3.0 & 0.07 \\
\hline $\mathrm{Yb}$ & 1.49 & 2.5 & & 1.9 & & 1.7 & 2.5 & 2.1 & 2.0 & 0.08 \\
\hline & Step 2 & & & & & & & & & \\
\hline & $\mathrm{L}_{0}=\mathrm{CLO} 4$ & $\mathrm{~L}_{2}=\mathrm{CL} 67$ & $\mathrm{~L}_{2}$ calc & & $\mathrm{L}_{2} \mathrm{Min}$ & L2 Max & $\mathrm{L}_{2}$ Average & $\mathrm{L}_{2}$ Median & D bulk & D** (HV1995) \\
\hline $\mathrm{Sc}$ & 30.1 & 19 & 20 & & 16 & 36 & 25 & 24 & 2.03 & $0.84-2.0$ \\
\hline V & 239 & 120 & 127 & & 105 & 270 & 165 & 160 & 2.56 & $0.8-2.6$ \\
\hline Co & 24 & 15.6 & 22 & & 10 & 24 & 18 & 19 & 1.21 & $1.2-1.7$ \\
\hline $\mathrm{Zn}$ & 84 & 77 & 62 & & 63 & 114 & 84 & 82 & 1.75 & $0.8-1.4$ \\
\hline $\mathrm{Rb}$ & 9.0 & 18 & 13 & & 9 & 23 & 18 & 18 & 0.08 & \\
\hline $\mathrm{Sr}$ & 348 & 339 & 325 & & 281 & 386 & 343 & 345 & 1.17 & $0.8-1.1$ \\
\hline $\mathrm{Ba}$ & 125 & 174 & 168 & & 75 & 215 & 171 & 176 & 0.27 & $0.21-0.31$ \\
\hline $\mathrm{Ce}$ & 14.6 & 19 & 20 & & 15 & 28 & 18 & 18 & 0.19 & \\
\hline $\mathrm{Eu}$ & 1.10 & 1.01 & 1.2 & & 0.9 & 1.2 & 1.0 & 1.0 & 0.72 & $0.72-0.81$ \\
\hline $\mathrm{Sm}$ & 3.1 & 3.1 & 3.9 & & 2.5 & 3.7 & 3.2 & 3.2 & 0.47 & $0.54-0.75$ \\
\hline $\mathrm{Yb}$ & 2.5 & 2.2 & 3.0 & & 1.4 & 2.5 & 2.1 & 2.1 & 0.52 & $0.75-0.93$ \\
\hline & Step 3 & & & & & & & & & \\
\hline & $\mathrm{L}_{0}=\mathrm{CL} 67$ & $\mathrm{~L}_{3}=\mathrm{CL} 40$ & & $\mathrm{~L}_{3}$ calc & & $\mathrm{L}_{3} \operatorname{Min}$ & $\mathrm{L}_{3} \operatorname{Max}$ & $\mathrm{L}_{3}$ Average & $\mathrm{L}_{3}$ Median & D bulk \\
\hline $\mathrm{Sc}$ & 19 & 14.5 & & 15 & & 12 & 29 & 20 & 19 & 1.71 \\
\hline V & 120 & 88 & & 82 & & 57 & 187 & 108 & 103 & 2.26 \\
\hline $\mathrm{Co}$ & 15.6 & 13.4 & & 14 & & 8 & 20 & 13 & 13 & 1.28 \\
\hline $\mathrm{Zn}$ & 77 & 73 & & 60 & & 53 & 139 & 79 & 76 & 1.82 \\
\hline $\mathrm{Rb}$ & 18 & 25 & & 24 & & 12 & 25 & 21 & 21 & 0.07 \\
\hline $\mathrm{Sr}$ & 339 & 370 & & 327 & & 274 & 381 & 342 & 339 & 1.12 \\
\hline $\mathrm{Ba}$ & 174 & 215 & & 218 & & 138 & 244 & 203 & 208 & 0.25 \\
\hline $\mathrm{Ce}$ & 19 & 20 & & 25 & & 17 & 25 & 21 & 20 & 0.15 \\
\hline $\mathrm{Eu}$ & 1.01 & 0.98 & & 1.1 & & 0.89 & 1.2 & 1.0 & 1.0 & 0.60 \\
\hline $\mathrm{Sm}$ & 3.1 & 3.1 & & 3.7 & & 2.8 & 4.0 & 3.3 & 3.3 & 0.38 \\
\hline $\mathrm{Yb}$ & 2.2 & 2 & & 2.6 & & 1.7 & 2.6 & 2.1 & 2.2 & 0.43 \\
\hline
\end{tabular}

*Average content of the 4 basalts in step 1

Min, max, average and median contents observed in samples having similar $\mathrm{SiO}_{2}$ content to CL04,CL67 or CL40

** Observed bulk partition coefficients between gabbronoritic enclaves and enclosing andesitic matrix (Hickey-Vargas et al., 1995)

Our model indicates that crystallization of a magma batch having the composition of the basalt CL119 (51.25 wt. $\% \mathrm{SiO}_{2}$ ) produces $63 \%$ cumulates that are mafic to intermediate $(24 \%$ troctolite $+25 \%$ amphibole-bearing gabbronorite $+14 \%$ diorite) and 37\% andesitic residual liquid (61.23 wt. $\% \mathrm{SiO}_{2}$ ). It agrees with the modelling of Namur et al. (2020) for the 2015 eruption who showed that $60 \%$ crystallization of a basaltic andesite $\left(52.0\right.$ wt. $\left.\% \mathrm{SiO}_{2}\right)$ 
produces a dacitic liquid (63.34 wt. \% $\mathrm{SiO}_{2}$ ). It also corroborates the semi-quantitative model of Lopez-Escobar et al. (1995) who proposed to derive the Calbuco andesites by subtraction of $30 \%$ cumulates, having the composition of the gabbronoritic xenoliths, from the composition of basaltic andesites taken from the nearby Osorno volcano as basalts/ basaltic andesites were lacking in their database (our step 2). However, a good match was not obtained for the trace elements probably because of geochemical differences between Osorno and Calbuco (Lopez-Escobar et al. 1995). These authors also suggested that the basaltic andesites could have been produced by fractionation of an assemblage made of olivine, clinopyroxene and plagioclase at moderate to high pressure from a basaltic composition. This hypothesis is supported by our basaltic samples and the step 1 of our quantitative model.

\section{Composition of glomerocrysts and cognate enclaves vs calculated cumulates}

The mineralogy and chemistry of the glomerocrysts corroborate the composition of the calculated cumulates. The troctolitic glomerocrysts (CL148, CL149) are similar to the first cumulate, an olivine-bearing gabbro (Table 4). The compositions of plagioclase $\left(\mathrm{An}_{86}\right)$ and olivine $\left(\mathrm{Fo}_{81}\right)$ calculated by Rhyolite-Melts (Gualda et al. 2012; Ghiorso and Gualda 2015) for the basalt CL119 liquidus are close to those measured in the glomerocryst $\left(\mathrm{An}_{92}-\mathrm{Fo}_{77.3}\right)$ but nevertheless suggest that their true parent magma had higher $\mathrm{Ca} / \mathrm{Na}$ and lower Mg\# than CL119 for the given $\mathrm{fO}_{2}$ and $\mathrm{H}_{2} \mathrm{O}$ content. However, Namur et al. (2020) reported a median of $\mathrm{An}_{87.7}$ for the An-rich cores of the 2015 eruption, which is close to the calculated value, and it is possible that Rhyolite-Melts overestimates the stability field of magnetite thus increasing the $\mathrm{Mg \#}$ of the derivative liquid. Using the average $\mathrm{Sr}$ and $\mathrm{Ba}$ contents of the plagioclase and the partition coefficients derived from the Blundy and Wood (1991) regression that depends on $T$ and $X_{\mathrm{An}}\left(D_{\mathrm{Sr}}=1.3 ; D_{\mathrm{Ba}}=0.12\right.$ at $\left.1100{ }^{\circ} \mathrm{C}, X_{\mathrm{An}}=0.9\right)$, the equilibrium melt had $373 \mathrm{ppm} \mathrm{Sr}$ and $112 \mathrm{ppm} \mathrm{Ba}$. These values are in very good agreement with the average $\mathrm{Sr}$ and $\mathrm{Ba}$ content of the 4 basalt samples collected for this study, respectively $391 \mathrm{ppm}$ and $104 \mathrm{ppm}$. The partition coefficients of Sc, V and Co between olivine and melt $(0.18,0.034,5$ : Table 5) result in calculated liquid composition (Sc:34 ppm, V: $258 \mathrm{ppm}, \mathrm{Co}: 37 \mathrm{ppm}$ ) that are in the range of those observed in the basalts (respectively 32 ppm, 249 ppm, 36 ppm: average of the 4 basalt samples). These results indicate that the basalts, particularly CL119, are plausible parent magmas for Calbuco and that the glomerocrysts are indeed parts of the crystal mush that were unlocked during eruption. The presence of olivine also supports the shallow pressure of solidification as, at higher pressure (CL119, $700 \mathrm{MPa}, \mathrm{FMQ}+2,3$ wt. \% $\mathrm{H}_{2} \mathrm{O}$ ),
Rhyolite-Melts predicts clinopyroxene and spinel as the liquidus phases in agreement with experimental data performed on similar compositions (Villiger et al. 2007). The second and third calculated cumulates are respectively amphibolebearing gabbronorite and norite and these lithologies were found as glomerocrysts and cognate enclaves (Hickey-Vargas et al. 1995) in the basaltic andesites and andesites. The cumulates that were produced during the upper crustal differentiation of the Calbuco basalts are thus mafic (gabbros, gabbronorites, norites) but nearly leucocratic (about 60\% plagioclase) with higher densities $\left(3000 \mathrm{~kg} / \mathrm{m}^{3}\right.$ : Table 4) than their coexisting melts (2500-2300 kg/m ${ }^{3}$ : Table 4). Interestingly, these lithologies are the principal components of the Miocene intrusions ( $\mathrm{K}-\mathrm{Ar}$ ages of Reloncavi: 12.8-10.3 Ma: Parada et al. 1987) that constitute the basement to the east and beneath Calbuco. These intrusions were emplaced at $200 \mathrm{MPa}$ (estimated with mineral parageneses of the surrounding gneisses) and belong to the North Patagonian batholith (Parada et al. 1987). This similarity of facies and depth of differentiation between volcanic and plutonic suites, even if having here different ages, supports the hypothesis that the plutonic basement corresponds to unlayered cumulates (Barnes et al. 2020). In several studies on granitic batholiths, it has indeed been concluded that wholerocks do not represent melt compositions but cumulates left over after the extraction of $\mathrm{SiO}_{2}$-rich liquids (Barnes et al. 2016; Bachmann and Huber 2019; Werts et al. 2020) and here too, crystal accumulation in cotectic proportions has been proposed to predict the overlapping experimental and observed trends (Barnes et al. 2016, 2020).

\section{The presence of amphibole}

Previously, Lopez-Escobar et al. (1995) proposed that the presence of amphibole could result from a higher $\mathrm{H}_{2} \mathrm{O}$ content in the Calbuco basalts compared with other SVZ volcanoes, an hypothesis supported by petrological data (3-3.5 wt. $\% \mathrm{H}_{2} \mathrm{O}$ in the Calbuco basalts vs. 1-2 wt. \% at Osorno (Bechon et al., in prep) and 1-2.5 wt.\% at La Picada (Vander Auwera et al. 2019). However, the stability of amphibole is not only dependent on the melt $\mathrm{H}_{2} \mathrm{O}$ content but also on pressure, temperature, oxygen fugacity and the melt major element composition (Sisson and Grove 1993; Putirka 2016; Humphreys et al. 2019). Petrological data indicate a similar depth (about $200 \mathrm{MPa}$ ) for the main magma storage of Calbuco, La Picada (Vander Auwera et al. 2019) and Osorno (Bechon et al., in prep). The Cpx-melt thermometry (Eq. 33 of Putirka (2008)) gives slightly lower temperatures at Calbuco (1080-981 $\left.{ }^{\circ} \mathrm{C}\right)$ that nevertheless overlap with the temperature ranges at Osorno $\left(1150-1030{ }^{\circ} \mathrm{C}\right.$ : Bechon et al. in prep) and La Picada (1143-1067 ${ }^{\circ} \mathrm{C}$ : Vander Auwera, et al. 2019). Oxygen fugacity is also not significantly different between Calbuco (NNO+0.9) and the two other volcanoes 
(NNO). Finally, the basalts analysed at the three volcanoes have similar compositions (Supplementary Fig. 10), especially in $\mathrm{Na}_{2} \mathrm{O}$ which partly controls the stability of amphibole (Sisson and Grove 1993). Consequently, a slight difference in the $\mathrm{H}_{2} \mathrm{O}$ content of the basalts remains the only plausible parameter that could determine the presence or not of amphibole at these volcanoes.

Lopez-Escobar et al. (1995) favored assimilation of metasedimentary rocks (metagreywackes, metapelites) as a source of $\mathrm{H}_{2} \mathrm{O}$ because the Calbuco lavas have higher ${ }^{87} \mathrm{Sr} /{ }^{86} \mathrm{Sr}$ and lower ${ }^{143} \mathrm{Nd} /{ }^{144} \mathrm{Nd}$ than the Osorno eruptive products. They proposed that bulk assimilation of a small amount $(10 \%)$ of a liquid produced by dehydration partial melting of metasedimentary wallrocks sufficiently increased the $\mathrm{H}_{2} \mathrm{O}$ content of a basalt similar to those found at Osorno. However, if we consider a conservative value of 2 wt. $\% \mathrm{H}_{2} \mathrm{O}$ in the Osorno basalt (Bechon, pers. comm.) and the $10 \%$ assimilation suggested by Lopez-Escobar et al. (1995), the partial melt must contain a minimum of $12 \mathrm{wt} \% \mathrm{H}_{2} \mathrm{O}$ to increase the $\mathrm{H}_{2} \mathrm{O}$ content of the basalt to 3 wt. \%. Using the muscovite dehydration-melting reaction proposed by Patiño Douce and Harris (1998) (22 Ms + $7 \mathrm{Pl}+8 \mathrm{Qz}=25 \mathrm{Melt}+5$ $\mathrm{Kfs}+5 \mathrm{Sil}+2 \mathrm{Bt}$ ), a plausible paragenesis in pelitic compositions just before partial melting, and an average of $4 \mathrm{wt} . \%$ $\mathrm{H}_{2} \mathrm{O}$ in muscovite and biotite results in a partial melt with 3.2 wt. $\% \mathrm{H}_{2} \mathrm{O}$. The necessary $\mathrm{H}_{2} \mathrm{O}$ content of the partial melt thus appears unrealistically high. It is also likely above the water solubility in these evolved melt compositions at shallow pressure (Holtz et al. 1992). Consequently, assimilation-contamination cannot be responsible for the higher water content of the Calbuco basalt. This characteristic is thus interpreted as derived from the primary mantle-derived magma. Sellés et al. (2004) also noted that assimilation of a metasedimentary crust was not supported by the low abundance of incompatible elements. Indeed, the Rb content, an important indicator of potential assimilation of metapelitic partial melts, is higher in the Osorno basalts (12-13.4 ppm at respectively 6.86 and 6.48 wt. \% MgO: Hickey-Vargas et al. (1986), Moreno et al. (2010)) than in the Calbuco basalts (9.3 ppm at 5.84 wt. \% $\mathrm{MgO}$ in basalt CL119). Likewise, the similar $\mathrm{K}_{2} \mathrm{O}$ content of the Calbuco (0.29-0.41 wt. \%) and Osorno (0.42-0.69 wt.\%: Moreno et al. (2010)) basalts is against significant assimilation as the experimental partial melt of Patiño Douce and Harris (1998) is enriched in $\mathrm{K}_{2} \mathrm{O}$ (4.6 wt\%). Finally, the different isotopic composition ( $\mathrm{Sr}$, $\mathrm{Nd}, \mathrm{Pb}$ ) between Osorno and Calbuco could be related to the variability of the ambient mantle wedge (mantle composition prior to the addition of a slab component) as proposed by Turner et al. (2017).

Amphibole and thus wet magmas are rare along the SVZ. It has been suggested that serpentinite bodies hosted in Fracture Zones (FZs) are the source of enhanced dewatering as for example, the Mocha, Chiloe and Valdivia FZs respectively for Nevado de Longavi (Rodriguez et al. 2007; Sellés et al. 2004), Calbuco and Mocho-Choshuenco volcanoes (Sellés et al. 2004) (Fig. 1). Hickey-Vargas et al. (2016b) later questioned this hypothesis in their study of along arc variation in the SVZ considering that the position of the Nazca plate FZs is not exactly matched by amphibole-bearing lithologies. Indeed, even if the Chiloe FZ is aligned with the position of Calbuco, Osorno and La Picada located just $20 \mathrm{~km} \mathrm{~N}$ of Calbuco, in the same alignment, lack amphibole. As the variable $\mathrm{H}_{2} \mathrm{O}$ content is inherited from the mantle source, it must correspond to a local mantle anomaly. If we assume a homogeneous water content in the mantle source beneath these three volcanoes, a higher water content of the primary magma could result from a lower degree of partial melting and thus a lower melting temperature beneath Calbuco. The $\mathrm{Nd}_{6.0}(\mathrm{Nd}$ content at 6 wt. \% $\mathrm{MgO}$ ), an indicator of the extent of partial melting (Turner et al. 2017), is indeed lower at Calbuco (7.3 ppm Nd at 5.84 wt. $\% \mathrm{MgO}$ ) than in the Osorno basalts ( 9.4 and $10.1 \mathrm{ppm} \mathrm{Nd}$ at respectively 6.86 and 6.48 wt. \% MgO: Hickey-Vargas et al. (1986); Moreno et al. (2010)) supporting this suggestion. Contrarily, the water content of the mantle source beneath Calbuco could be higher also resulting in a higher degree of partial melting (e.g. Kelley et al. 2010). This heterogeneity in the mantle $\mathrm{H}_{2} \mathrm{O}$ content (Baker et al. 1994) could itself be driven by a locally higher flux from the slab. Calbuco basalts are characterized by lower $(\mathrm{La} / \mathrm{Sm})_{N},(\mathrm{La} / \mathrm{Yb})_{N}$ and $\mathrm{Th} / \mathrm{Yb}$ than the basalts from Osorno and La Picada suggestive of a lower input from the subducted sediments (Elliott 2003) (Supplementary Fig. 11). In the current state of knowledge, we would thus favor the first hypothesis, a local lower degree of partial melting resulting from the mantle wedge thermal structure.

\section{The Daly gap and the dacites}

Dacites are minor eruptive products at Calbuco. They have been described by Sellés and Moreno (2011) as subordinated compositions in Unit 2 and recorded in only two of their samples. They have not been mapped as individual domes such as in Osorno (Moreno et al. 2010) and Villarrica (Moreno and Clavero 2006) or as dykes (La Picada: Vander Auwera et al. (2019)), but given the less favorable outcrop conditions at Calbuco, their exact proportions is unclear. As observed in the La Picada lavas (Vander Auwera et al. 2019), a compositional gap separates the most evolved andesites (61.87 wt. $\% \mathrm{SiO}_{2}$ ) from the dacites (64.75 wt. \% $\mathrm{SiO}_{2}$ ) but it is slightly displaced towards more $\mathrm{SiO}_{2}$-rich compositions than at La Picada (57.0-62.7 wt. \% $\mathrm{SiO}_{2}$ ). The composition of the AEMs and of the 2015 interstitial dacitic melt (Namur et al. 2020) plot within the gap demonstrating that these "missing" compositions were indeed produced during differentiation in the storage region. The lower limit of the gap 
corresponds to the critical crystallinity threshold (Table 4: $63 \%$ fractionation at 61 wt. $\% \mathrm{SiO}_{2}$ ), a situation similar to that of La Picada, and we follow here the same interpretation: at this stage, the proportion of crystals was high enough for the magma to behave like a solid preventing its eruption. A local process (e.g. gas-driven filter pressing, modification in regional stress) eventually enables the extraction of the dacitic interstitial melt from the crystal mush with possible eruption of a dacitic lava flow. The low abundance of dacites at Calbuco and at the other volcanoes could indicate that successful separation between the dacitic melt from the crystalline matrix is not a frequent process and/or that this dacitic melt is generally too viscous to erupt.

The higher water content of the Calbuco magmas (3-3.5 wt.\% in the basalts) compared to La Picada (1-2 wt\% in the basalts) decreased their viscosity thus likely resulting in a Daly gap starting at a higher $\mathrm{SiO}_{2}$ content for the same crystal fraction. Also, Blatter et al. (2017) experimentally demonstrated that in dacitic melts the crystallization of amphibole is produced by a perictectical distributary reaction between pyroxenes, plagioclase and melt with a high latent heat and a low variance. This source of heat could further lower the magma viscosity contributing to the higher $\mathrm{SiO}_{2}$ at the start of the Daly gap. We also note that the most abundant lavas, the more eruptable, correspond to the compositional range where amphibole is stable (54-57 wt. \% $\mathrm{SiO}_{2}$ ) (Fig. 7). Namur et al. (2020) previously stressed the possible role of the high latent heat of crystallization of amphibole in favoring the extraction of the dacitic melt from the crystal mush for the 2015 eruption.

\section{Possible differentiation from the primary magma to the parent basalt}

The Calbuco basalts cannot be primary magmas in equilib-

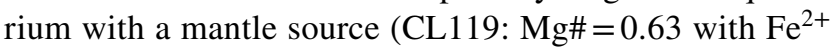
calculated at $\mathrm{FMQ}+2,41 \mathrm{ppm} \mathrm{Cr}, 35 \mathrm{ppm} \mathrm{Ni}$, compared to accepted values of $\mathrm{Mg \#}>0.7,>1000 \mathrm{ppm} \mathrm{Cr},>150 \mathrm{ppm}$ $\mathrm{Ni}$ after Baker et al. (1994)) indicating some differentiation from the mantle melt to the basaltic composition. Primary magmas have not been observed at Calbuco but the most magnesian olivine (CL112A: $\mathrm{Fo}_{88.3}$ ) is in equilibrium with a melt having a $\mathrm{Mg \#}$ of 0.69 , very close to the accepted minimum value of 0.70 and primary magmas occur at Osorno (Moreno et al. 2010) and Villarrica (Hickey-Vargas et al. 2016b) (Supplementary Fig. 10). These primary magmas are compositionally similar to sample SH 85-44 (Mount Shasta, Cascades) that was shown to have last equilibrated at a shallow mantle depth $(1.0 \mathrm{GPa})$ below a thin crust (30 km) (Baker et al. 1994) (Supplementary Fig. 10), conditions that correspond to this part of the SVZ where the crust is 30-40 km thick (Vander Auwera et al. 2019; Watt et al. 2013). Differentiation from the primary magma to the basalt could have occurred at a shallow level as no sign of high pressure fractionation has been found in the Calbuco mineral composition and the few primary magmas sampled in the SVZ demonstrate that they can ascend to the upper crust. However, a lower crustal process is also possible given the higher density of primary magmas (Putirka 2017). This latter hypothesis is supported by recent results on small eruptive centers related to Villarrica that suggest a basaltic deep reservoir (32-44 km: Morgado et al. 2015).

The trace element compositions of the basalts demonstrate that fractionation of garnet and of significant plagioclase were not involved in their petrogenesis: low $(\mathrm{La} / \mathrm{Yb})_{N}$ ratios (1.37-1.76 in the basalts from our dataset and 2.06 for sample SCA-053A of Sellés and Moreno (2011)), Sr/Y (Y partitions into garnet and amphibole) ratios ranging from 17.2 to 29.2 and the lack of Eu anomaly $\left(\mathrm{Eu} / \mathrm{Eu}^{*}=1.03-1.08\right.$ and 1.02 for SCA-053A). This agrees with fractionation at both low and high pressure. Indeed, at low pressure, the experimental data of Grove et al. (2003) acquired on sample SH 85-44 (200 MPa, $\mathrm{H}_{2} \mathrm{O}$-saturated, NNO) indicate that olivine and clinopyroxene are early liquidus phases whereas at high pressure, Müntener et al. (2001) (1.2 GPa, 4-5 wt. $\% \mathrm{H}_{2} \mathrm{O}, \mathrm{FMQ}$ ) and Ulmer et al. (2018) (1.0 GPa, NNO, 5 wt. $\left.\% \mathrm{H}_{2} \mathrm{O}, \mathrm{NNO}\right)$, using the same starting composition, showed that olivine is replaced by orthopyroxene. At both pressures, the early ultramafic cumulates lack Al-rich phases and produce a residual basaltic melt enriched in $\mathrm{Al}_{2} \mathrm{O}_{3}(20.8$ wt. \% in run B659 of Müntener et al. (2001) and 19.0 in run 85-44 \#7 of Grove et al. (2003)) as observed in basalt CL119 (19.99 wt. \%). In the case of lower crustal differentiation, the low density of CL119 $\left(2610 \mathrm{~kg} / \mathrm{m}^{3}\right.$ :Rhyolite-Melts: 2.9 wt. $\% \mathrm{H}_{2} \mathrm{O}$ at $1.0 \mathrm{GPa}$ ) compared to that of both pyroxenes (orthopyroxene: $3220 \mathrm{~kg} / \mathrm{m}^{3}$, clinopyroxene: $3260 \mathrm{~kg}$ / $\mathrm{m}^{3}$ ) and more generally to that of the average lower crust (2900-3100 kg/m $\mathrm{m}^{3}$ between 30 and $40 \mathrm{~km}$ depth: Christensen and Mooney (1995); Putirka (2017)) indicates that the residual basaltic melt was very buoyant and prone to ascend in the upper crust (Fig. 14) as buoyancy has been identified as the main parameter controlling magma ascent.

\section{Conclusions}

Based on our observations, we can conclude that the magmatic system beneath Calbuco has been stationary for about $340 \mathrm{ky}$ and mostly erupted basaltic andesites and to a lesser extent andesites. The presence of amphibole discriminates Calbuco from nearby volcanoes and results from a higher $\mathrm{H}_{2} \mathrm{O}$ content of the tholeiitic parent basalts, a feature possibly resulting from a lower degree of partial melting induced by the mantle wedge thermal structure. The Calbuco differentiation trend approximates a liquid line of descent as it is overlapped by calculated melts in equilibrium with 
Fig. 14 Schematic sketch of the magmatic system below Cabuco (Crystals: red = plagioclase; blue $=$ olivine; green = clinopyroxene; dark green $=$ orthopyroxene; brown = amphibole; dark grey $=$ Ti-magnetite; bubbles = volatile exsolution). ICD = Intracrustal discontinuity from Tassara and Echaurren (2012) and Tassara et al. (2006). A primary mantle melt fractionates close to the $\mathrm{MOHO}$ or at shallow pressure to produce an $\mathrm{Al}_{2} \mathrm{O}_{3}$-rich basaltic melt having the composition of the Calbuco parent magma. Chemical diversity from basalt to dacite is acquired in the main storage region. Mostly basaltic andesites and andesites are erupted

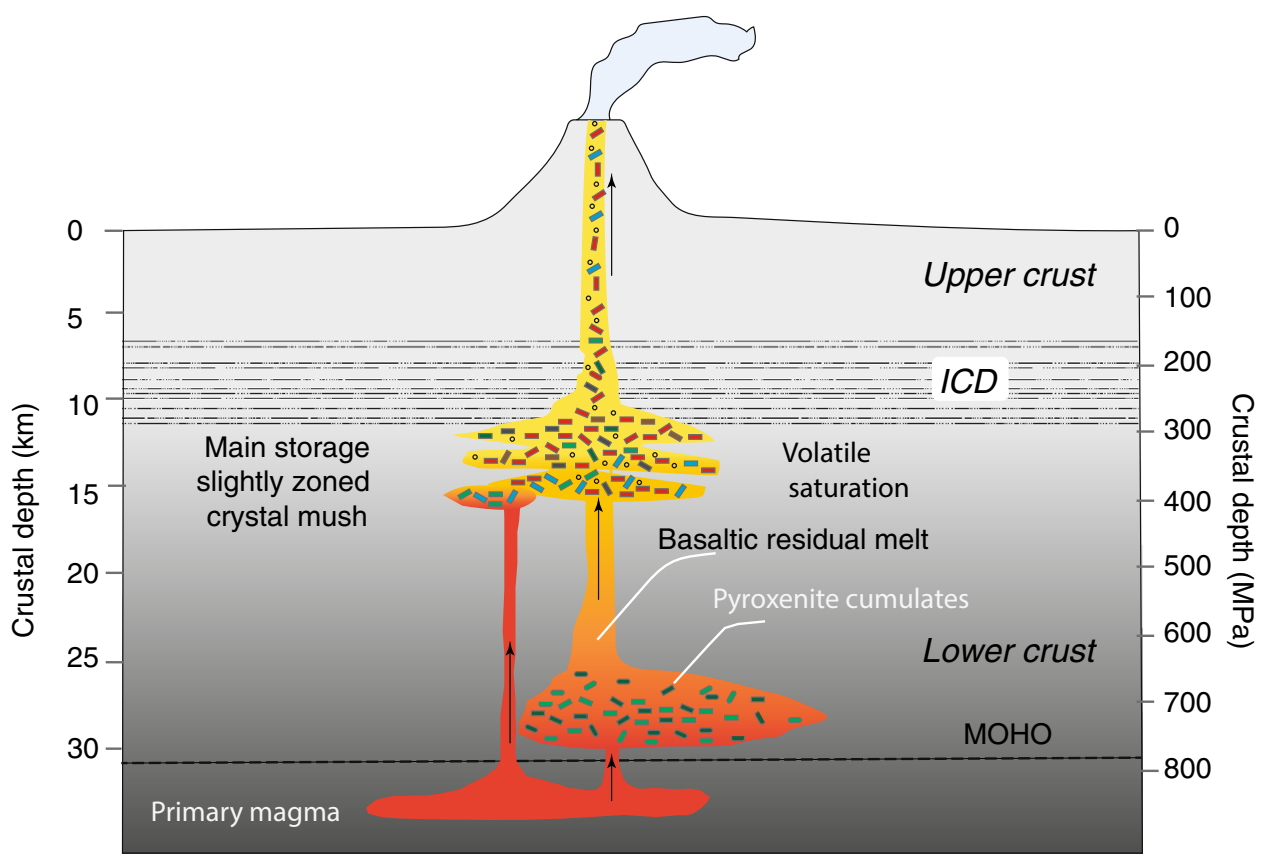

amphibole as well as experimental liquid lines of descent. On the other hand, macrocrysts are not all in equilibrium with their host lava and were unlocked from the crystal mush of the magma storage region. Reconciling these contradictory observations can be made if macrocrysts are transported in nearly cotectic proportions, a hypothesis that mirrors the supposed accumulation of minerals in cotectic proportions in granitoids interpreted as the roots of now eroded volcanoes.

The magmatic system beneath Calbuco probably starts with a primary mantle melt, similar to those observed at nearby Osorno, that likely fractionates ultramafics cumulates either close to the MOHO or at shallower depth to produce an $\mathrm{Al}_{2} \mathrm{O}_{3}$-rich basaltic residual melt. This basalt or the primary magma ascend through the upper crust, possibly along local fractures/faults and stalls between 210 and $460 \mathrm{MPa}$, the level of volatile saturation and of the intracrustal discontinuity. There, most of the chemical diversity from basalt to dacite is produced. Fractional crystallization of this basalt produces plagioclase-rich and amphibole-bearing gabbros to gabbronorites, lithologies that are observed in the basement Miocene shallow-level plutonic rocks of the North Patagonian batholith. The rare dacites are interpreted as melt-dominated magmas that are extracted from the solid matrix when critical crystallinity is reached in the crystal mush and are eventually able to erupt despite their higher viscosity. Our model of the Calbuco magmatic system thus focuses on shallow crustal process as the main vectors of chemical diversity. The thin crust as well as the strike-slip regime imposed by the LOFZ likely control the development of a shallow reservoir at Calbuco (Chaussard and Amelung 2014), which increases the risk of eruption.
Supplementary Information The online version contains supplementary material available at https://doi.org/10.1007/s00410-021-01803-7.

Acknowledgements Luis Lara is greatly thanked for his help in the organization of the fieldwork. Pia Plese participated to the 2016 fieldwork. This research was supported by FNRS Grants CDR J.00066.14, PDR T.0079.18 to JVDA. ON acknowledges support from the FWO through an Odysseus grant. We thank our reviewers for providing constructive comments that improved this work.

\section{References}

Adam J, Green T (2006) Trace element partitioning between mica- and amphibole-bearing garnet lherzolite and hydrous basanitic melt: 1. Experimental results and the investigation of controls on partitioning behaviour. Contrib Miner Petrol 152:1-17

Aigner-Torres M, Blundy J, Ulmer P, Pettke T (2007) Laser Ablation ICPMS study of trace element partitioning between plagioclase and basaltic melts: an experimental approach. Contrib Miner Petrol 153:647-667

Almeev R, Holtz F, Ariskin A, Kimura J (2013) Storage conditions of Bezymianny Volcano parental magmas: results of phase equilibria experiments at 100 and $700 \mathrm{MPa}$. Contrib Miner Petrol 166:1389-1414

Angermann D, Klotz J, Reigber C (1999) Space-geodetic estimation of the Nazca-South America Euler vector. Earth Planet Sci Lett 171(3):329-334

Arzilli F, Morgavi D, Petrelli M, Polacci M, Burton M, Di Genova D, Spina L, La Spina G, Hartley M, Romero J (2019) The unexpected explosive sub-Plinian eruption of Calbuco volcano (22-23 April 2015; southern Chile): triggering mechanism implications. J Volcanol Geotherm Res 378:35-50

Bachmann O, Huber C (2019) The Inner workings of crustal distillation columns; the physical mechanisms and rates controlling phase separation in silicic magma reservoirs. J Petrol 60(1):3-18 
Bachmann O, Deering C, Ruprecht J, Huber C, Skopelitis A, Schnyder C (2011) Evolution of silicic magmas in the Kos-Nisyros volcanic center, Greece: a petrological cycle associated with caldera collapse. Contrib Miner Petrol 163(1):151-166

Bacon CR, Druitt TH (1988) Compositional evolution of the zoned calc-alkaline magma chamber of Mount Mazama, Crater Lake, Oregon. Contrib Miner Petrol 98:224-256

Baker M, Grove TL, Price R (1994) Primitive basalts and andesites from Mt. Shasta region, N. California: products of varying fraction and water content. Contrib Miner Petrol 118:111-129

Barclay J, Carmichael ISE (2004) A hornblende basalt from western Mexico: water-saturated phase relations constrain a pressuretemperature window of eruptibility. J Petrol 45(3):485-506

Barnes C, Coint N, Yoshinobu A (2016) Crystal accumulation in a tilted arc batholith. Am Miner 101:1719-1734

Barnes C, Werts K, Memeti V, Ardill K (2020) Most granitoid rocks are cumulates: deductions from hornblende compositions and zircon saturation. J Petrol 60:11

Beattie P (1994) Systematics and energetics of trace-element partitioning between olivine and silicate melts: implications for the nature of mineral/melt partitioning. Chem Geol 117(1):57-71

Bédard J (2005) Partitioning coefficients between olivine and silicate melts. Lithos 83:394-419

Bédard J (2006) Trace element partitioning in plagioclase feldspar. Geochim Cosmochim Acta 70:3717-3742

Bédard J (2007) Trace element partitioning coefficients between silicate melts and orthopyroxene: parameterizations of $\mathrm{D}$ variations. Chem Geol 244:263-303

Bédard JH (2014) Parameterizations of calcic clinopyroxene-Melt trace element partition coefficients. Geochem Geophys Geosyst 15(2):303-336

Blatter D, Sisson T, Hankins W (2013) Crystallization of oxidized, moderately hydrous arc basalt at mid- to lower-crustal pressures: implications for andesite genesis. Contrib Miner Petrol 166:861-886

Blatter D, Sisson TW, Hankins W (2017) Voluminous arc dacites as amphibole reaction-boundary liquids. Contrib Miner Petrol $172: 27$

Blundy J, Wood BJ (1991) Crystal-chemical controls on the partitioning of $\mathrm{Sr}$ and $\mathrm{Ba}$ between plagioclase feldspar, silicate melts, and hydrothermal solutions. Geochim Cosmochim Acta 55:193-209

Blundy J, Wood BJ (2003) Partitioning of trace elements between crystals and melts. Earth Planet Sci Lett 210:383-397

Blundy J, Cashman KV, Rust A, Witham F (2010) A case for $\mathrm{CO}_{2}$-rich arc magmas. Earth Planet Sci Lett 290(3):289-330. https://doi. org/10.1016/j.epsl.2009.12.013

Boudreau AE (2019) The effects of volatiles on mineral stability and volatile fluxing. In: Boudreau A (ed) Hydromagmatic processes and platinum-group element deposits in layered intrusions. Cambridge University Press, Cambridge, pp 140-155

Bouvet de Maisonneuve C, Dungan MA, Bachmann O, Burgisser A (2012) Insights into shallow magma storage and crystallization at Volcán Llaima (Andean Southern Volcanic Zone, Chile). J Volcanol Geotherm Res 211-212:76-91. https://doi.org/10.1016/j. jvolgeores.2011.09.010

Bouvet De Maisonneuve C, Dungan MA, Bachmann O, Burgisser A (2013) Petrological insights into shifts in eruptive styles at Volcán Llaima (Chile). J Petrol 54(2):393-420. https://doi.org/10. 1093/petrology/egs073

Cashman KV, Blundy J (2013) Petrological cannibalism: the chemical and textural consequences of incremental magma body growth. Contrib Miner Petrol 166:703-729

Cashman K, Sparks R, Blundy J (2017) Vertically extensive and unstable magmatic systems: a unified view of igneous processes. Science 355:6331
Castruccio A, Clavero J, Segura A, Samaniego P, Roche O, Le Pennec J-L, Droguett B (2016) Eruptive parameters and dynamics of the April 2015 sub-Plinian eruptions of Calbuco volcano (southern Chile). Bull Volcanol 78:62

Cembrano J, Lara L (2009) The link between volcanism and tectonics in the Southern Volcanic Zone of the Chilean Andes: a review. Tectonophysics 471:96-113

Charlier B, Grove TL, Namur O, Holtz F (2018) Crystallization of the lunar magma ocean and the primordial mantle-crust differentiation of the Moon. Geochim Cosmochim Acta 234:50-69

Chaussard E, Amelung F (2014) Regional controls on magma ascent and storage in volcanic arcs. Geochem Geophys Geosyst 15(4):1407-1418. https://doi.org/10.1002/2013gc005216

Christensen N, Mooney W (1995) Seismic velocity structure and composition of the continental crust: a global view. J Geophys Res 100(B7):9761-9788

Clayton J, Clapperton C, Antinao J (1997) Las glaciaciones pleistocenas en la cuenca del lago Villarrica, Andes del Sur. In: Congreso Geológico Chileno, vol 8. Antofagasta, pp 307-311

Cooper K, Kent A (2014) Rapid remobilization of magmatic crystals kept in cold storage. Nature 506:480-483

Dixon J (1997) Degassing of alkalic basalts. Am Miner 82:368-378

Dostal J, Dupuy C, Carron JP, Dekerneizon ML, Maury RC (1983) Partition coefficients of trace elements-application to volcanic rocks of St-Vincent West-Indies. Geochim Cosmochim Acta 47(3):525-533

Dunn T, Sen C (1994) Mineral/matrix partition-coefficients for orthopyroxene, plagioclase and olivine in basaltic to andesitic systems - a combined analytical and experimental study. Geochim Cosmochim Acta 58(2):717-733

Dzierma Y, Thorwart M, Rabbel W (2012) Moho topography and subducting oceanic slab of the Chilean continental margin in the maximum slip segment of the $1960 \mathrm{Mw} 9.5$ Valdivia (Chile) earthquake from P-receiver functions. Tectonophysics 530-531:180-192

Eichelberger J, Izbekov P, Browne B (2006) Bulk chemical trends at arc volcanoes are not liquid lines of descent. Lithos 87:135-154

Elliott T (2003) Tracers of the slab. In: Eiler J (ed) Inside the subduction factory, Geophysical Monograph 138. American Geophysical Union, Washington DC, USA, pp 23-45

Erdmann S, Martel C, Pichavant M, Kushnir A (2014) Amphibole as an archivist of magmatic crystallization conditions: problems, potential, and implications for inferring magma storage prior to the paroxysmal 2010 eruption of Mount Merapi, Indonesia. Contrib Miner Petrol 167:1016

Ewart A, Griffin W (1994) Application of proton-microprobe data to trace-element partitioning in volcanic rocks. Chem Geol 117:251-284

Frost B, Frost C (2019) Essentials of igneous and metamorphic petrology. Cambridge University Press, Cambridge

Gallahan W, Nielsen R (1992) The partitioning of Sc, Y, and the rare earth elements between high-Ca pyroxene and natural mafic to intermediate lavas at 1 atmosphere. Geochim Cosmochim Acta 56(6):2387-2404

Ghiorso MS, Gualda G (2015) An $\mathrm{H}_{2} \mathrm{O}-\mathrm{CO}_{2}$ mixed fluid saturation model compatible with Rhyolite-MELTS. Contrib Miner Petrol 169:53. https://doi.org/10.1007/s00410-015-1141-8

Ghiorso MS, Sack RO (1991) Thermochemistry of the oxide minerals. Rev Min 25:221-264

Glazner AF, Bartley JM, Coleman DS, Gray W, Taylor RZ (2004) Are plutons assembled over millions of years by amalgamation from small magma chambers? GSA Today 14(4/5):4-11

Grove TL, Donnelly-Nolan JM, Housh T (1997) Magmatic processes that generated the rhyolite of Glass Mountain, Medicine Lake volcano, N California. Contrib Miner Petrol 127:205-223 
Grove TL, Elkins-Tanton LT, Parman SW, Chatterjee N, Müntener O, Gaetani GA (2003) Fractional crystallization and mantle-melting controls on calc-alkaline differentiation trends. Contrib Miner Petrol 145:515-533

Grove TL, Till CB, Krawczynski MJ (2012) The role of $\mathrm{H}_{2} \mathrm{O}$ in subduction zone magmatism. Annu Rev Earth Planet Sci 40:413-439

Gualda G, Ghiorso MS, Lemons R, Carley T (2012) Rhyolite-MELTS: a modified calibration of MELTS optimized for silica-rich, fluidbearing magmatic systems. J Petrol 53:875-890

Gudmundsson A (2012) Magma chambers: formation, local stresses, excess pressures, and compartments. J Volcanol Geotherm Res 237-238:19-41. https://doi.org/10.1016/j.jvolgeores.2012.05.015

Harrison TM, Watson EB (1984) The behavior of apatite during crustal anatexis: equilibrium and kinetic considerations. Geochim Cosmochim Acta 48:1467-1477

Hauri EH, Wagner TP, Grove TL (1994) Experimental and natural partitioning of $\mathrm{Th}, \mathrm{U}, \mathrm{Pb}$ and other trace elements between garnet, clinopyroxene and basaltic melts. Chem Geol 117(1):149-166. https://doi.org/10.1016/0009-2541(94)90126-0

Hayes J, Deligne N, Bertin L, Calderon R, Wardman J, Wilson T, Leonard G, Stewart C, Wallace K, Baxter P (2019) Impacts of the 2015 eruption of Calbuco volcano on Chilean infrastructure, utilities, agriculture and health. Geol Nucl Sci Rep 4:102

Hickey RL, Frey FA, Gerlach DC (1986) Multiple sources for basaltic arc rocks from the Southern Volcanic Zone of the Andes (34 ${ }^{\circ}$ $41^{\circ} \mathrm{S}$ ): trace element and isotopic evidence for contributions from subducting oceanic crust, mantle, and continental crust. J Geophys Res 91:5963-5983

Hickey-Vargas R, Abdollahi MMA, Lopez-Escobar L, Frey FA (1995) Crustal xenoliths from Calbuco Volcano, Andean Southern Volcanic Zone: implications for crustal composition and magmacrust interaction. Contrib Miner Petrol 119:331-344

Hickey-Vargas R, Holbik S, Tormey D, Frey FA, Moreno Roa H (2016b) Basaltic rocks from the andean southern volcanic zone: insights from the comparison of along-strike and small-scale geochemical variations and their sources. Lithos 258-259:115132. https://doi.org/10.1016/j.lithos.2016.04.014

Hickey-Vargas R, Sun M, Holbik S (2016a) Geochemistry of basalts from small eruptive centers near Villarrica stratovolcano, Chile: evidence for lithospheric mantle components in continental arc magmas. Geochim Cosmochim Acta 185:358-382

Higgins M, Voos S, Vander Auwera J (2015) Magmatic processes under Quizapu Volcano, Chile, identified from geochemical and textural studies. Contrib Miner Petrol 170:51-67

Holloway J, Burnham C (1972) Melting relations of basalt with equilibrium water pressures less than total pressure. J Petrol 13:1-30

Holtz F, Pichavant M, Barbey P, Johannes W (1992) Effects of $\mathrm{H}_{2} \mathrm{O}$ on liquidus phase relations in the haplogranite system at 2 and 5 kbar. Am Miner 77:1223-1241

Huber C, Townsend M, Degruyter W, Bachmann O (2019) Optimal depth of subvolcanic magma chamber growth controlled by volatiles and crust rheology. Nat Geosci 12(9):1-7

Humphreys MCS, Cooper G, Zhang J, Loewen M, Kent A, Macpherson C, Davidson J (2019) Unravelling the complexity of magma plumbing at Mount St. Helens: a new trace element partitioning scheme for amphibole. Contrib Miner Petrol 174(1):9

Irvine T, Baragar W (1971) A guide to chemical classification of common volcanic rocks. Can J Earth Sc 8:523-548

Jackson M, Blundy J, Sparks RSJ (2018) Chemical differentiation, cold storage and remobilization of magma in the Earth's crust. Nature 564:405-409

Kawamoto T (1996) Experimental constraints on differentiation and $\mathrm{H}_{2} \mathrm{O}$ abundance of calc-alkaline magmas. Earth Planet Sci Lett 144:577-589
Kelley K, Plank T, Ludden J, Staudigel H (2003) Composition of altered oceanic crust at ODP Sites 801 and 1149. Geochem Geophys Geosyst 4(6):8910

Kelley KA, Plank T, Newman S, Stolper EM, Grove TL, Parman S, Hauri EH (2010) Mantle melting as a function of water content beneath the Mariana Arc. J Petrol 51:1711-1738

Lachance G, Traill R (1966) A practical solution to the matrix problem in X-ray analysis. Can J Spectrosc 11:43-46

Laubier M, Grove TL, Langmuir C (2014) Trace element mineral/melt partitioning for basaltic and basaltic andesitic melts: an experimental and laser ICP-MS study with application to the oxidation state of mantle source regions. Earth Planet Sci Lett 392:265-278

Leake B, Wooley A, Arps C, Birch W, Gilbert M, Grice J, Hawthorne F, Kato A, Kisch H, Krivovichev V, Linthout K, Laird J, Mandarino J, Maresch W, Nickel E, Schumacher J, Smith D, Stephenson N, Ungaretti L, Whittaker E, Youzhi G (1997) Nomenclature of amphiboles: report of the subcommittee on amphiboles of the international mineralogical association, commission on new minerals and names. Can Mineral 35:219-246

Leake B, Wooley A, Birch W, Burke E, Ferraris G, Grice J, Hawthorne F, Kisch H, Krivovichev V, Schumacher J, Stephenson N, Whittaker E (2003) Nomenclature of amphiboles: additions and revisions to the international mineralogical association's 1997 recommendations. Can Mineral 41:1355-1362

Lemarchand F, Benoit V, Calais G (1987) Trace element distribution coefficients in alkaline series. Geochim Cosmochim Acta 51:1071-1081

Longhi J, Walker D, hays J (1976) Fe and Mg in plagioclase. In: Proceedings 7th Lunar Science Conference, 1:1281-1300.

Longhi J, Vander Auwera J, Fram M, Duchesne JC (1999) Some phase equilibrium constraints on the origin of Proterozoic (Massif) anorthosites and related rocks. J Petrol 40(2):339-362

Longpré M-A, Stix J, Costa F, Espinoza E, Munoz A (2014) Magmatic processes and associated timescales leading to the january 1835 eruption of Cosiguina volcano. Nicaragua. J Petrol 55(6):1173-1201

Lopez-Escobar L, Parada M, Moreno RH, Frey FA, Hickey-Vargas R (1992) A contribution to the petrogenesis of Osorno and Calbuco volcanoes, Southern Andes (41 $-41^{\circ} 30^{\prime}$ S): comparative study. Rev Geol Chile 19(2):211-226

Lopez-Escobar L, Parada M, Hickey-Vargas R, Frey F, Kempton P, Moreno H (1995) Calbuco volcano and minor eruptive centers distributed along the Liquiñe-Ofqui Fault Zone, Chile $\left(41^{\circ}\right.$ $42^{\circ} \mathrm{S}$ ): contrasting origin of andesitic and basaltic magma in the Southern Volcanic Zone of the Andes. Contrib Miner Petrol 119:345-361

Lucassen F, Wiedicke M, Franz G (2010) Complete recycling of a magmatic arc: evidence from chemical and isotopic composition of Quaternary trench sediments in Chile $\left(36^{\circ}-40^{\circ} \mathrm{S}\right)$. Intern J Earth Sci 99:687-701

Martel C, Pichavant M, Holtz F, Scaillet B, Bourdier J-L, Traineau $\mathrm{H}$ (1999) Effects of $f_{\mathrm{O} 2}$ and $\mathrm{H}_{2} \mathrm{O}$ on andesite phase relations between 2 and 4 kbar. J Geophys Res 104:29453-29470

Montalbano S (2018) Processus de différenciation et sources des magmas du volcan Calbuco (Zone Volcanique Sud, Chili). PhD dissertation, University of Liege

Moore G, Carmichael IS (1998) The hydrous phase equilibria (to $3 \mathrm{kbar}$ ) of an andesite and basaltic andesite from western Mexico: constraints on water content and conditions of phenocryst growth. Contrib Miner Petrol 130:304-319

Moreno R H, Clavero J (2006) Geologia del volcan Villarrica. Servicio Nacional de Geologie y Mineria, Carta Geologica de Chile, Santiago 
Moreno H, Lara L, Orozco G (2010) Geologia del volcan Osorno, Region de Los Lagos. Servicio Nacional de Geologie y Mineria, Carta Geologica de Chile, Santiago

Morgado E, Parada M, Contreras C, Castruccio A, Gutiérrez F, McGee LE (2015a) Contrasting records from mantle to surface of two nearby arc volcanic complexes: Caburgua-Huelemolle Small Eruptive Centers and Villarrica Volcano. J Volcanol Geotherm Res 306:1-16

Morgado E, Morgan D, Castruccio A, Ebmeier S, Parada M, Brahm R, Harvey J, Gutiérrez F, Walshaw R (2019b) Old magma and a new, intrusive trigger: using diffusion chronometry to understand the rapid-onset Calbuco eruption, April 2015 (Southern Chile). Contrib Miner Petrol 174:61

Morgado E, Morgan D, Harvey J, Parada M-A, Castruccio A, Brahm R, Gutierrez F, Georgiev B, Hammond S (2019) Localised heating and intensive magmatic conditions prior to the 22-23 April 2015 Calbuco volcano eruption (Southern Chile). Bull Volcanol 81(4):24

Müntener O, Kelemen P, Grove T (2001) The role of $\mathrm{H}_{2} \mathrm{O}$ during crystallization of primitive arc magmas under uppermost mantle conditions and genesis of igneous pyroxenites: an experimental study. Contrib Miner Petrol 141:643-658

Namur O, Charlier B (2012) Efficiency of compaction and compositional convection during mafic crystal mush solidification: the Sept Iles layered intrusion, Canada. Contrib Miner Petrol 163(6):1049-1068. https://doi.org/10.1007/s00410-011-0715-3

Namur O, Abily B, Boudreau A, Blanchette F, Bush J, Ceuleneer G, Charlier B, Donaldson C, Duchesne J, Higgins M, Morata D, Nielsen T, O', Driscoll B, Pang K, Peacock T, Spandler C, Toramaru A, Veksler I, JA (2015) Igneous Layering in basaltic magma chambers. In: Charlier B et al. (eds) Layered Intrusions, Springer, pp 75-152

Namur O, Montalbano S, Bolle O, Vander Auwera J (2020) Petrology of the April 2015 eruption of Calbuco volcano, southern Chile. J Petrol 61(8). https://doi.org/10.1093/petrology/egaa084

Nandedkar R, Ulmer P, Müntener O (2014) Fractional crystallization of primitive hydrous arc magmas: an experimental study at 0.7 GPa. Contrib Miner Petrol 167:1015-1041

Neave D, Putirka KD (2017) A new clinopyroxene-liquid barometer, and implications for magma storage pressures under Icelandic rift zones. Am Miner 102:777-794

Neave DA, Maclennan J, Hartley M, Edmonds M, Thordarson T (2014) Crystal storage and transfer in basaltic systems: the Skuggafjöll eruption, Iceland. J Petrol 55(12):2311-2346

Panjasawatwong Y, Danyushevsky L, Crawford A, Harris K (1995) An experimental study of the effects of melt composition on plagioclase-melt equilibria at 5 and 10 kbar: implications for the origin of magmatic high — an plagioclase. Contrib Miner Petrol 118:420-432

Parada M, Godoy E, Hervé F, Thiele R (1987) Miocene calc-alkaline plutonism in the Chilean Southern Andes. Revista Brasileira De Geociências 17(4):450-455

Parat F, Streck M, Holtz F, Almeev R (2014) Experimental study into the petrogenesis of crystal-rich basaltic to andesitic magmas at Arenal volcano. Contrib Miner Petrol 168:1040

Patiño Douce A, Harris N (1998) Experimental constraints on Himalayan anatexis. J Petrol 39(4):689-710

Peccerillo A, Taylor SR (1976) Geochemistry of Eocene calc-alkaline volcanic rocks from the Kastamonu area, Northern Turkey. Contrib Miner Petrol 58:63-81

Petrelli M, Caricchi L, Perugini D (2020) Machine learning thermobarometry: application to clinopyroxene-bearing magmas. J Geophys Res 125. https://doi.org/10.1029/2020JB020130.

Pichavant M, Macdonald R (2007) Crystallization of primitive basaltic magmas at crustal pressures and genesis of calc-alkaline igneous suite: experimental evidence from St Vincent, Lesser Antilles arc. Contrib Miner Petrol 154:535-558

Pichavant M, Martel C, Bourdier J-L, Scaillet B (2002) Physical conditions, structure and dynamics of a zoned magma chamber: Mt. Pelée (Martinique, Lesser Antilles arc). J Geophys Res 107(B5):ECV 1-1-ECV 1-28

Pioli L, Scalisi L, Constantini L, Di Muro A, Bonadonna C, Clavero $\mathrm{J}$ (2015) Explosive style, magma degassing and evolution in the Chaimilla eruption, Villarrica volcano, Southern Andes. Bull Volcanol 77:93

Plank T (2014) The chemical composition of subducting sediments. In: Rudnick R (ed) Treatise on Geochemistry 2nd Edition, vol 3: The Crust. Elsevier, pp 607-629

Plank T, Kelley K, Zimmer M, Hauri E, Wallace PJ (2013) Why do mafic arc magmas contain $\approx 4$ wt $\%$ water on average? Earth Planet Sci Lett 364:168-179

Porter S (1981) Pleistocene glaciation in the southern Lake District of Chile. Quatern Res 16(3):263-292

Putirka KD (2008) Thermometers and barometers for volcanic systems. Rev Mineral Geochem 69:61-120

Putirka KD (2016) Amphibole thermometers and barometers for igneous systems and some implications for eruption mechanisms of felsic magmas at arc volcanoes. Am Miner 101(4):841-858

Putirka KD (2017) Down the crater: where magmas are stored and why they erupt. Elements 13:11-16

Ridolfi F, Renzulli A (2012) Calcic amphiboles in calc-alkaline and alkaline magmas: thermobarometric and chemometric empirical equations valid up to $1,130^{\circ} \mathrm{C}$ and $2.2 \mathrm{GPa}$. Contrib Miner Petrol 163(5):877-895.https://doi.org/10.1007/s00410-011-0704-6

Ridolfi F, Renzulli A, Puerini M (2010) Stability and chemical equilibrium of amphibole in calc-alkaline magmas: an overview, new thermobarometric formulations and application to subductionrelated volcanoes. Contrib Miner Petrol 160(1):45-66

Rodriguez C, Dungan M, Sellés D, Langmuir C (2007) Adakitic dacites formed by intracrustal crystal fractionation of water-rich parent magmas at Nevado de Longavi volcano (36.2 ${ }^{\circ} \mathrm{S}$; Andean Southern Volcanic Zone, Central Chile). J Petrol 48(11):2033-2061

Roeder PL, Emslie RF (1970) Olivine-liquid equilibrium. Contrib Miner Petrol 19:275-289

Romero J, Morgavi D, Arzilli F, Daga R, Caselli A, Reckziegel F, Viramonte J, Diaz-Alvarado J, Polacci M, Burton M, Perugini D (2016) Eruption dynamics of the 22-23 April 2015 Calbuco Volcano (Southern Chile): analyses of tephra fall deposits. J Volcanol Geotherm Res 317:15-29

Rubin A, Cooper K, Till C, Kent A, Costa F, Bose M, Gravley D, Deering C, Cole J (2017) Rapid cooling and cold storage in a silicic magma reservoir recorded in individual crystals. Science 356:1154-1156

Ruth DCS, Cottrell E, Cortés JA, Kelley KA, Calder ES (2016) From passive degassing to violent strombolian eruption: the case of the 2008 Eruption of Llaima Volcano, Chile. J Petrol 57(9):18331864. https://doi.org/10.1093/petrology/egw063

Rutherford M, Hill P (1993) Magma ascent rates from amphibole breakdown: an experimental study applied to the 1980-1986 Mount St. Helens eruptions. J Geophys Res 98(B11)

Sellés D, Moreno H (2011) Geologia del volcan Calbuco. Servicio Nacional de Geologie y Mineria, Carta Geologica de Chile, Santiago

Sellés D, Rodriguez A, Dungan M, Naranjo J, Gardeweg M (2004) Geochemistry of Nevado de Longavi Volcano $\left(36.2^{\circ} \mathrm{S}\right)$ : a compositionally atypical arc volcano in the Southern Volcanic Zone of the Andes. Revista Geologica de Chile 31(2):293-315

Sievwright RH, Wilkinson C, O'Neill HCC, Berry AJ (2017) Thermodynamic controls on element partitioning between 
titanomagnetite and andesitic-dacitic silicate melts. Contrib Miner Petrol 172:62

Sigmarsson O, Laporte D, Carpentier M, Devouard B, Devidal J-L, Marti J (2013) Formation of U-depleted rhyolite from a basanite at El Hierro, Canary Islands. Contrib Miner Petrol 165:601-622

Sisson TW, Grove TL (1993) Experimental investigations of the role of $\mathrm{H}_{2} \mathrm{O}$ in calc-alkaline differentiation and subduction zone magmatism. Contrib Miner Petrol 113:143-166

Solano J, Jackson M, Sparks RSJ, Blundy J (2014) Evolution of major and trace element composition during melt migration through crystalline mush: implications for chemical differentiation in the crust. Am J Sci 314:895-939

Stormer J, Nicholls J (1978) XLFRAC: a program for the interactive testing of magmatic differentiation models. Comput Geosci 4(2):143-159

Sun S, McDonough W (1989) Chemical and isotopic systematics of oceanic basalts: implications for mantle composition and processes. In: Saunders A, Norry M (eds) Magmatism in the ocean basins, vol 42, Blackwell Scientific publications, pp 313-345

Syracuse EM, Abers GA (2006) Global compilation of variations in slab depth beneath arc volcanoes and implications. Geochem Geophys Geosyst 7(5). https://doi.org/10.1029/2005GC001045

Tassara A, Echaurren A (2012) Anatomy of the Andean subduction zone: three dimensional density model upgraded and compared against global-scale models. Geophys J Int 189:161-168

Tassara A, Götze H, Schmidt S, Hackney R (2006) Three-dimensional density model of the Nazca plate and the Andean continental margin. J Geophys Res 111:B09404. https://doi.org/10.1029/ 2005JB003976.

Tegner C, Thy P, Holness MB, Jakobsen JK, Lesher CE (2009) Differentiation and compaction in the Skaergaard Intrusion. J Petrol 50(5):813-840. https://doi.org/10.1093/petrology/egp020

Toplis M, Corgne A (2002) An experimental study of element partitioning between magnetite, clinopyroxene and iron-bearing silicate liquids with particular emphasis on vanadium. Contrib Miner Petrol 144:22-37

Turner S, Langmuir C, Dungan M, Escrig S (2017) The importance of mantle wedge heterogeneity to subduction zone magmatism and the origin of EM1. Earth Planet Sci Lett 472:216-228

Ulmer P, Kaegi R, Müntener O (2018) Experimentally derived intermediate to silica-rich arc magmas by fractional and equilibrium crystallization at $1.0 \mathrm{GPa}$ : an evaluation of phase relationships, compositions, liquid lines of descent and oxygen fugacity. J Petrol 59(2):11-58

Van Achterberg E, Ryan C, Jackson S, Griffin W (2001) Data reduction software for LA-ICP-MS. In: Sylveter P (ed)
Laser-ablation-ICPMS in the earth sciences: principles and applications, Mineralogical Association of Canada Short Course, vol 29, pp 239-243

Van Eaton A, Amigo Á, Bertin D, Mastin L, Giacosa R, González J, Valderrama Ó, Fontijn K, Behnke S (2016) Volcanic lightning and plume behavior reveal evolving hazards during the April 2015 eruption of Calbuco volcano, Chile. Geophys Res Lett 43(7):3563-3571

Vander Auwera J, Namur O, Dutrieux A, Wilkinson C, Ganerød M, Coumont V, Bolle O (2019) Mantle melting and magmatic processes under La Picada stratovolcano (CSVZ, Chile). J Petrol 60(5):873-906

Villiger S, Ulmer P, Müntener O (2007) Equilibrium and fractional crystallization experiments at $0.7 \mathrm{GPa}$; the effect of pressure and phase relations and liquid compositions of tholeiitic magmas. $\mathrm{J}$ Petrol 48(1):159-184

Wallace P (2005) Volatiles in subduction zone magmas: concentrations and fluxes based on melt inclusion and volcanic gas data. $\mathrm{J}$ Volcanol Geotherm Res 140:217-240

Watt SFL, Pyle DM, Mather TA, Naranjo JA (2013) Arc magma compositions controlled by linked thermal and chemical gradients above the subducting slab. Geophys Res Lett 40:2550-2556

Weller D, Stern C (2018) Along-strike variability of primitive magmas (major and volatile elements) inferred from olivine-hosted melt inclusions, southernmost Andean Southern Volcanic Zone, Chile. Lithos 296:233-244

Werts K, Barnes C, Memeti V, Paterson S, Ratschbacher B, Williams D (2020) Hornblende as a tool for assessing mineral-melt equilibrium and recognition of crystal accumulation. Am Miner 105:77-91

Whitney D, Evans B (2010) Abbreviations for names of rock-forming minerals. Am Miner 95:185-187

Wood BJ, Blundy J (1997) A predictive model for rare earth element partitioning between clinopyroxene and anhydrous silicate melt. Contrib Miner Petrol 129:166-181

Zhang J, Humphreys MCS, Cooper G, Davidson J, Macpherson C (2017) Magma mush chemistry at subduction zones, revealed by new melt major element inversion from calcic amphiboles. Am Miner 102:1353-1367

Publisher's Note Springer Nature remains neutral with regard to jurisdictional claims in published maps and institutional affiliations. 